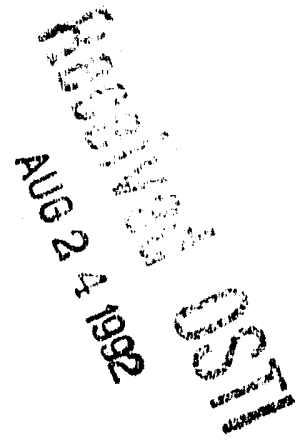

\title{
Hanford Radiological Protection Support Services Annual Report for 1991
}
M. Lyon
T. J. Froelich
D. E. Bihl
J. A. Leonwich
J. J. Fix
T. P. Lynch
R. K. Piper

July 1992

Prepared for the U.S. Department of Energy under Contract DE-AC06-76RLO 1830

Pacific Northwest Laboratory

Operated for the U.S. Department of Energy

by Battelle Memorial institute

\section{* Battelle}




\title{
DISCLAIMER
}

This report was prepared as an account of work sponsored by an agency of the United States Government. Neither the United States Government nor any agency thereof, nor Battelle Memorial Institute, nor any of their employees, makes any warranty, expressed or implied, or assumes any legal liability or responsibility for the accuracy, completeness, or usefulness of any information, apparatus, product, or process disclosed, or represents that its use would not infringe privately owned rights. Reference herein to any specific commercial product, process, or service by trade name, trademark, rnanufacturer, or otherwise does not necessarily constitute or imply its endorsement, recommendation, or favoring by the United States Government or any agency thereof, or Baltelle Memorial Institule. The views and opinions of authors expressed herein do not necessarily state or reflect those of the United States Government or any agency thereof.

\author{
PACIFIC NORTHWEST LABORATORY \\ operated by \\ BATTELLE MEMORIAL INSTITUTE \\ for the \\ UNITED STATES DEPARTMENT OF ENERGY \\ under Contract DE-AC06-76RLO 1830
}

Printed in the United States of America

Available to DOE and DOE contractors from the

Office of Scientific and Technical Information, P.O. Box 62, Oak Ridge, TN 37031; prices available from (615) 576-8401. FTS 626-8401.

Availahle to the public from the National Technical Information Service, U.S. Department of Commerce, 5245 Port Royal Rd., Springfield, VA 22161. 
HANFORD RADIOLOGICAL

PROTECTION SUPPORT SERVICES

ANNUAL REPORT FOR 199 !
M. Lyon
T. J. Froelich
D. E. Binl
J. A. Leonwich
J. J. Fix
T. P. Lynch
R. K. Piper

July 1992

Prepared for

the U.S. Department of Energy

under Contract DE-AC06-76RLO 1830

Pacific Northwest Laboratory

Richland, Washington 99352

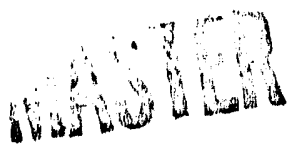




\section{ABSTRACT}

Various Hanford sitewide radiation protection services provided by the Pacific Northwest Laboratory for the U.S. Department of Energy, Richland Field Office and Hanford contractors are described in this annual report for calendar year 1991. These activities include internal dosimetry measurements and evaluations, in vivo measurements, external dosimetry measurements and evaluations, instrument calibration and evaluation, radiation source calibration, and radiological records keeping. For each of these activities, the routine program, program changes and enhancements, associated tasks, investigations and studies, and related publications, presentaticns, and other staff professional activities are discussed as applicable. 


\section{SUMMARY}

This report documents the performance of certain radiological protection sitewide services during calendar year (CY) 1991 by the Pacific Northwest Laboratory, : :upporting the U.S. Department of Energy (DOE), Richland Field Office (RL) and contractor activities on the Hanford Site. The routine program for each service is discussed along with any significant program changes and tasks, investigations, and studies performed in support of each program. Other related activities such as publications, presentations, and memberships on standards or industry committees are also discussed. The programs covered provide services in the areas of 1) internal dosimetry, 2) in vivo measurements, 3) external dosimetry, 4) instrument calibration and evaluation, 5) calibration of radiation sources traceable to the National Institute of Standards and Technology, and 6) radiological records.

The Haniord Internal Dosimetry Program provides bioassay monitoring and associated evaluation and documentation of assessments of internal exposure and dose to Hanford personnel and Hanford Site visitors. During 1990, the Internal Dosimetry Program periormed 20,777 excreta and in vivo bloassay measurements. One hundred twenty-nine assessments of potential new intakes and one reassessment of prior exposure were performed. Over $98 \%$ of the measurements were classified as routine, $1 \%$ were due to intake follow-up, and $1 \%$ were classified as special purpose measurements. During the year, the interim excreta bioassay program continued, which had started in 1990 with the termination of the U.S. Testing Company contract. A new long-term analytical contract was awarded in October to International Technology Analytical Services. In addition to the many changes required by the interim program and integration of the analytical laboratory, tasks included adoption of the Code for Internal Dosimetry (CINDY) as an additional tool for bloassay analysis and internal dose calculations, a revision to the Technical Basis for Internal Dosimetry at Hanford, and development of a method for identifying workers performing environmental restoration and remediation work who should be included in the bioassay program.

The Hanford in Vivo Measurement Program is an integral part of personnel dosimetry at Hanford and provides for the detection of radioactivity materials deposited in Hanford Site employees and visitors. The program provided a total of 13,909 measurements during $\mathrm{CY}$ 1991. Changes to facilities and equipment included addition of a second workstation as a backup, improved measurements of chest-wall thickness, installation of oxygen monitoring systems in the counting cells with automatic fill liquid nitrogen systems, and startup and operation of the remote in vivo counting system in the 200-East Area. Special studies and other changes incorporated into the program included special chest counting studies; evaluation of nuclide library and peak search routines; an aggressive onsite maintenance program to improve the reliability of planar germanium detectors; and developrnent of a scheduling and tracking system, a database, and administrative procedures for the phantom libraiy. 
The Hanford External Dosimetry Program successfully met all external program reviews during 1991. Feported doses for blind audit dosimeters provided monthly by Westinghouse Hanford Company (WHC) along with their personnel dosimeters met all established criteria. The program participated in formal DOE Laboratory Accreditation Program (DOELAP) dosimeter performance testing during 1991. Reported results for Hanford basic, beta/photon, and multipurpose dosimeters met DOELAP criteria in all tested categories. During 1991, approximately 200,000 dosimeters were process $9 d$. Dose-of-record information was reported to the Radiological Records Program for 87,044 personnel dosimeters. Technical evaluations were conducted of 1) comparison of reported dose between 1989 and 1991 DOEL.AP tested algorithms, 2) analysis of lower level of detection, 3) figld measurements of dosimeter response to plutonium metal, hexafluoride, plutonium oxide, and californium neutron sources, 4) personnel measurements using Hanford combination albedo and track-etch dosimeters, 5) glow curve analysis capabilities, 6) performance testing automated reader systems to 500 rad, and 7) investigation of the ultraviolet response of Hanford multipurpose dosimeters.

The Instrument Calibration and Evaluation Program provides complete and reliable radiation protection instrument services for Hanford Site contractors to ensure personnel safety in the Hanford workplace. Specific tasks performed under this program during 1991 included the conduct of the routine instrument pool, the Hanford Instrument Evaluation Program, the calibration of WHC 200-Area alpha constant air monitors, and the testing and evaluation of a new generation of alpha continuous air monitors. Tasks performed during the year that supported the routine program included the design and fabrication of multi-range performance test source holders for beta and alpha survey instruments. During the last part of the year, analytical equipment was acquired and procedures written to support an instrument check source and calibration source verification plan, which was initiated in $\mathrm{CY}$ 1992.

The Radiation Standards and Calibration Project maintains radiological calibration standards, special instrument, and dosimeter response-characterizing equipment and calibration data-handling equipment at Hanford. The project is divided into two major functions: 1) maintenance of calibration standards and capabilities, and 2) maintenance of the instrument calibration and repair data management system. Improvements to the project during 1991 included construction of a deuteriated water $\left(D_{2} O\right)$ delivery system for the ${ }^{252} \mathrm{Cf}$ neutron sources, and data storage media upgrades within the calibration data management sysiem. Investigative studies and corrective action plans were made regarding elevated neutron background levels in control room areas and nearby $x$-ray calibration facilities.

The Hanford Radiological Records Program preserves and administers all records of personnel radiological exposure and Hanford historical radiation protection and radiological dosimetry practices since the inception of Hanford in the early 1940s. During 1991, the Radiological Records Program operated the Occupational Radiation Exposure system and the Hanford Radiation Protection Historical Files in support of the RL and Hanford contractor 
radiological protection and dosimetry programs. The program produced reports for DOE (RL and Headquarters), Hanford Site contractors, and individuals, and assisted in epidemiological and historical research. Development of the Radiation Exposure system (REX) continued during the year. The development project completed the preliminary design phase, including the alternatives analysis that selected the hardware and software. The project then moved into the detailed design and construction phase, which continued for the remainder of the year. It was also decided to incorporate a laser optical disk subsystem into the REX development. The only significant change to the program was the addition of a periodic download of active employee exposure data to the Hanford Environmental Health Foundation for use by their physicians. 


\section{ACKNOWLEDGMENTS}

The authors would like to thank the staff members whose professional skills and technical expertise ensure the success of Hanford's External Dosimetry Program, Internal Dosimetry Program, In Vivo Measurement Program, Instrument Calibration Program, Radiological Records Program, and Radiation Standards and Calibrations Project. 


\section{ACRONYMS}

\begin{tabular}{|c|c|}
\hline $\begin{array}{l}\text { ACL } \\
\text { ANSI }\end{array}$ & $\begin{array}{l}\text { PNL Analytical Chemistry Laboratory } \\
\text { American National Standards Institute }\end{array}$ \\
\hline BCSA & Boeing Computer Services-Richland \\
\hline $\begin{array}{l}\text { CAM } \\
\text { CAR } \\
\text { CINDY } \\
\text { CP } \\
\text { CY }\end{array}$ & $\begin{array}{l}\text { continuous air monito } \\
\text { computer-assisted retrieval } \\
\text { Code for internal Dosimetry } \\
\text { cutie pie } \\
\text { calendar year }\end{array}$ \\
\hline $\begin{array}{l}\text { DEC } \\
\text { DOE } \\
\text { DOELAP }\end{array}$ & $\begin{array}{l}\text { Digital Equipment Corporation } \\
\text { U.S. Department of Energy } \\
\text { DOE Laboratory Accreditation Program }\end{array}$ \\
\hline EDF & Emergency Decontamination Facility \\
\hline GM & Geiger-Mueller \\
\hline $\begin{array}{l}\text { HDPE } \\
\text { HEHF } \\
\text { HIEC } \\
\text { HP } \\
\text { HQ } \\
\text { HRRP }\end{array}$ & $\begin{array}{l}\text { high density polyethylene } \\
\text { Hanford Environmental Health Foundation } \\
\text { Hanford Instrument Evaluation Committee } \\
\text { Hewlett Packard } \\
\text { DOE Headquarters } \\
\text { Hanford Radiological Records Program }\end{array}$ \\
\hline $\begin{array}{l}\text { IDP } \\
\text { ITAS } \\
\text { IU } \\
\text { IVRRF }\end{array}$ & $\begin{array}{l}\text { Hanford Internal Dosimetry Program } \\
\text { International Technology Analytical Services } \\
\text { isotopic uranium } \\
\text { In Vivo Radioassay Research Facility }\end{array}$ \\
\hline KEH & Kaiser Engineers Hantord Company \\
\hline $\begin{array}{l}\text { LANL } \\
\text { LLNL } \\
\text { LOD } \\
\text { LSIS }\end{array}$ & $\begin{array}{l}\text { Los Alamos National Laboratory } \\
\text { Lawrence Livermore National Laboratory } \\
\text { laser optical disk } \\
\text { Large Scale Information System NSAS } 9080 \text { mainframe }\end{array}$ \\
\hline $\begin{array}{l}\text { MCA } \\
\text { MDA } \\
\text { MO } \\
\text { MQA } \\
\text { mrem }\end{array}$ & $\begin{array}{l}\text { multichannel analyzer } \\
\text { minimum detectable activity } \\
\text { magneto-optical disk drive } \\
\text { measurement quality assurance } \\
\text { millirem }\end{array}$ \\
\hline
\end{tabular}


NIST National Institute of Standards and Tөchnology

ORE Occupational Radiation Exposure system

ORNL Oak Ridge National Laboratory

PAM portable alpha monitor

PC personal computer

PNL Pacific Northwest Laboratory

QA quality assurance

QC quality control

QUS quick uranium soluble

RDBMS relational database management system

REECo Reynolds Electric and Engineering Company

RESL DOE Radiological and Environmental Sciences Laboratory

REX Radiation Exposure system

RL DOE Richland Field Otfice

AS\&C Radiation Standards and Calibrations Project

SDD Software design document

SOW statement of work

TEPC tissue equivalent proportional counter

TLD thermoluminescent dosimeter

TMA TMA Corporation (TMANorcal)

TRU transuranic radionuclides

USDT U.S. Dosimetry Technology

UST U.S. Testing, Inc.

UV ultraviolet

WHC Westinghouse Hanford Company 


\section{TABLE OF CONTENTS}

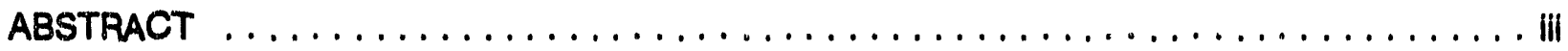

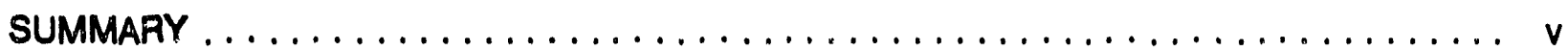

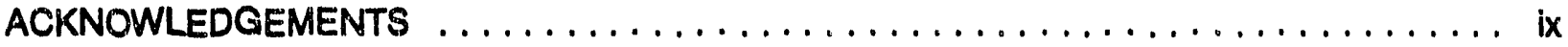

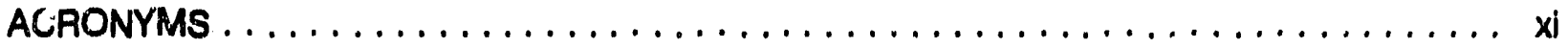

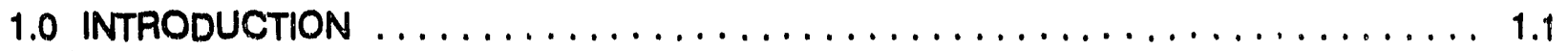

2.0 HANFORD INTERNAL DOSIMETRY PROGRAM $\ldots \ldots \ldots \ldots \ldots \ldots \ldots \ldots \ldots \ldots$

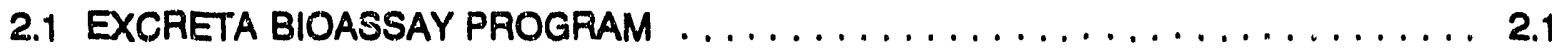

2.1 .1 Interim Program $\ldots \ldots \ldots \ldots \ldots \ldots \ldots \ldots \ldots \ldots \ldots \ldots \ldots \ldots \ldots \ldots$

2.1.2 Now Long-Term Contract $\ldots \ldots \ldots \ldots \ldots \ldots \ldots \ldots \ldots \ldots \ldots$

2.1.3 Quality Control Audit Program . . . . . . . . . . . . . 2.7

2.1.4 Omenn Committee Investigation . . . . . . . . . . . . . . 2.8

2.2 ROUTINE INTERNAL DOSIMETRY PROGRAM $\ldots \ldots \ldots \ldots \ldots \ldots \ldots \ldots \ldots$

2.2.1 Testing and Implementation of the Code for Internal Dosimetry . . . . 2.10

2.2.2 Revision of the Technical Basis for Internal Dosimetry at Hanford . . . . . . 2.11

2.2.3 Bioassay Criteria for Environmental Restoration Workers . . . . . . . . . 2.12

2.3 MONITORING AND ASSESSMENT ACTIVITIES $\ldots \ldots \ldots \ldots \ldots \ldots \ldots \ldots \ldots .2 .12$

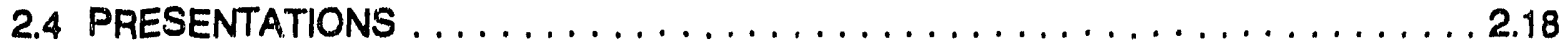

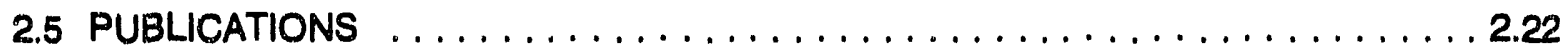

2.6 PROGRAM-RELATED PROFESSIONAL ACTIVITIES $\ldots \ldots \ldots \ldots \ldots \ldots \ldots \ldots .2 .22$

3.0 HANFORD IN VIVO MEASUREMENT PROGRAM $\ldots \ldots \ldots \ldots \ldots \ldots \ldots \ldots \ldots . .1$

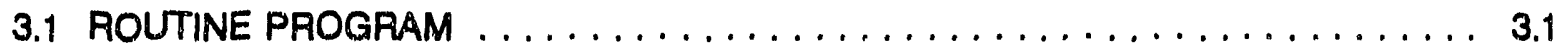

3.2 ADDITIONS OR CHANGES TO EQUIPMENT AND FAGILITIES IN $1991 \ldots \ldots \ldots$

3.2.1 Workstations $\ldots \ldots \ldots \ldots \ldots \ldots \ldots \ldots \ldots \ldots \ldots \ldots \ldots$ 
3.2.2 Improved Measurements of Chest-Wall Thickness . . . . . . . . . . 3.6

3.2 .3 Counting Cell Safety $\ldots \ldots \ldots \ldots \ldots \ldots \ldots \ldots \ldots \ldots \ldots \ldots$

3.2.4 Operation of the Remotely Operated in Vivo Counting System . . . . . . . 3.6

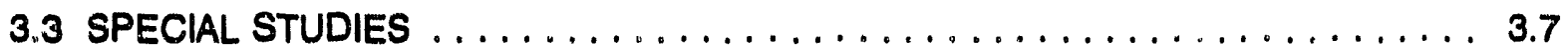

3.3.1 Chest Counting Studies $\ldots \ldots \ldots \ldots \ldots \ldots \ldots \ldots \ldots \ldots \ldots . \ldots \ldots$

3.3.2 Evaluation of Radionuclide Library and Peak Search Routines . . . . . . . 3.9

3.3.3 Maintenance of the Planar Germanium Detectors $\ldots \ldots \ldots \ldots \ldots \ldots$

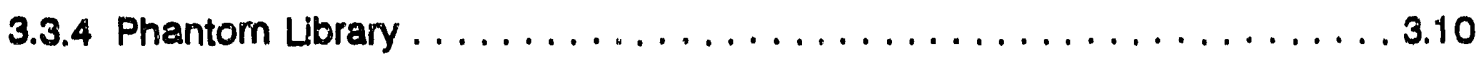

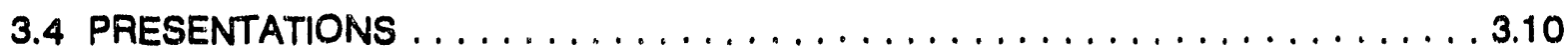

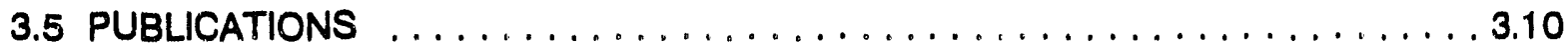

3.6 PROGRAM-RELATED PROFESSIONAL ACTIVITIES $\ldots \ldots \ldots \ldots \ldots \ldots \ldots \ldots .11$

4.0 HANFORD EXTERNAL DOSIMETRY PROGRAM $\ldots \ldots \ldots \ldots \ldots \ldots \ldots \ldots \ldots$

4.1 EXTERNAL PERFORMANCE TESTING EVALUATIONS $\ldots \ldots \ldots \ldots \ldots \ldots \ldots .1$

4.1.1 WHC Audit Dosimeters . . . . . . . . . . . . . . . . . . 4.1

4.1.2 DOELAP Performance Testing $\ldots \ldots \ldots \ldots \ldots \ldots \ldots \ldots \ldots \ldots$

4.1.3 Comparison of 1989 and 1991 DOELAP Tested Algorithms . . . . . . . 4.2

4.2 ROUTINE PROGRAM $\ldots \ldots \ldots \ldots \ldots \ldots \ldots \ldots \ldots \ldots \ldots \ldots \ldots \ldots$

4.2.1 Routine Processing $\ldots \ldots \ldots \ldots \ldots \ldots \ldots \ldots \ldots \ldots \ldots \ldots \ldots$

4.2.2 Reporting Selected Neutron Dose Results with a Note Code $53 \ldots \ldots$. . . 4.4

4.3 SUPPORTING EVALUATIONS $\ldots \ldots \ldots \ldots \ldots \ldots \ldots \ldots \ldots \ldots \ldots \ldots \ldots$

4.3.1 Analysis of Lower Level of Detection $\ldots \ldots \ldots \ldots \ldots \ldots \ldots \ldots$

4.3.2 Field Measurements . . . . . . . . . . . . . . . . . . . 4.6

4.3.3 Hanford Combination Albedo and Track-Etch Dosimeters . . . . . . . 4.6

4.3.4 Glow Curve Analysis $\ldots \ldots \ldots \ldots \ldots \ldots \ldots \ldots \ldots \ldots \ldots \ldots .7$ 
4.3.5 Periormance Testing of Reader Systems to 500 Rad . . . . . . . . . 4.7

4.3.6 Ultraviolet Pesponse of Hantord Dosimeters . . . . . . . . . . . . 4.8

4.4 DOCUMENTATION ............................. 4.9

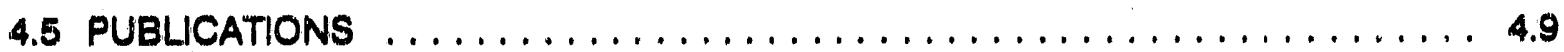

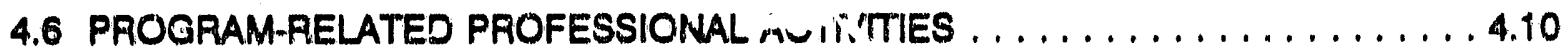

5.0 INSTRUMENT CALIBRATION AND EVALUATION

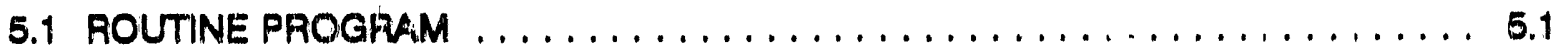

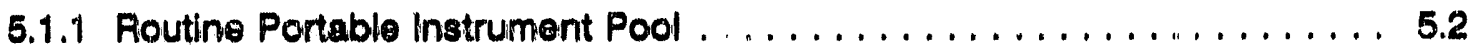

5.1 .2 Hanford Instrument Evaluation Program . . . . . . . . . . . . 5.2

5.1.3 Calibration of WHC 200-Area Alpha Continuous Air Monitors . . . . . . . 5.4

5.1.4 Tosting and Evaluation of a New-Generation Alpha Continuous Air Monitors $\ldots \ldots \ldots \ldots \ldots \ldots \ldots \ldots \ldots \ldots \ldots \ldots \ldots . \ldots \ldots \ldots$

5.2 SUPPORTING INVESTIGATION ANJ STUDIES $\ldots \ldots \ldots \ldots \ldots \ldots \ldots \ldots$

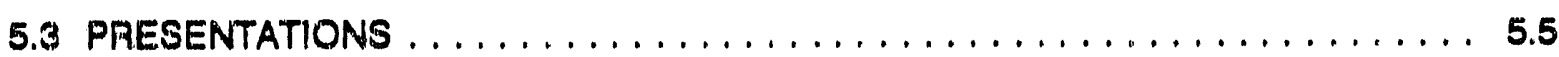

5.4 PROGAAM-RELATED PROFESSIONAL ACTIVITIES $\ldots \ldots \ldots \ldots \ldots \ldots \ldots$

6.0 RADIATION STANDARDS AND CALIBRATIONS PROJECT $\ldots \ldots \ldots \ldots \ldots \ldots \ldots . \ldots . \ldots$

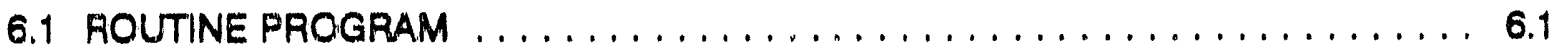

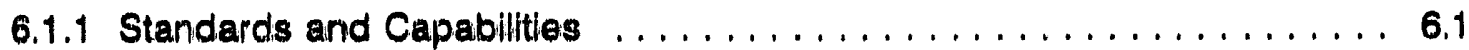

6.1 .2 Callbrations and Constancy Checks . . . . . . . . . . . . 6.7

6.1 .3 Measurement Quality Assurance $\ldots \ldots \ldots \ldots \ldots \ldots \ldots \ldots \ldots . \ldots \ldots$

6.1 .4 Improvements to Standards and Capabilities . . . . . . . . . . . 6.7

6.1.5 Maintenance of the Data Management System . . . . . . . . . . 6.8

6.1 .6 Improvements to the Data Management System . . . . . . . . . . . 6.9

6.2 SUPPORTING INVESTIGATIONS AND STUDIES $\ldots \ldots \ldots \ldots \ldots \ldots \ldots \ldots .11$

7.0 HANFORD RADIOLOGICAL RECORDS PROGHAM $\ldots \ldots \ldots \ldots \ldots \ldots \ldots \ldots \ldots$ 


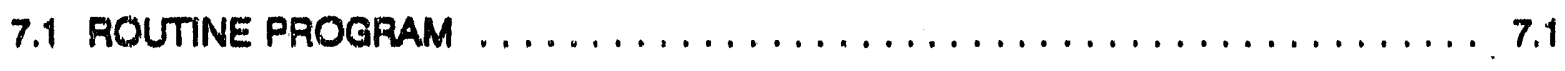

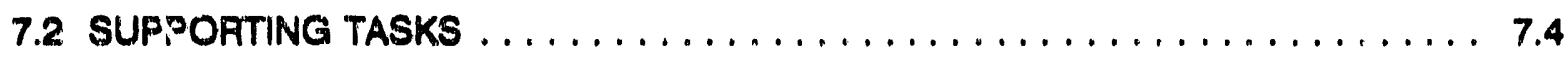

7.3 LASER OPTICAL DISK SUBSYSTEM $\ldots \ldots \ldots \ldots \ldots \ldots \ldots \ldots \ldots \ldots .6$

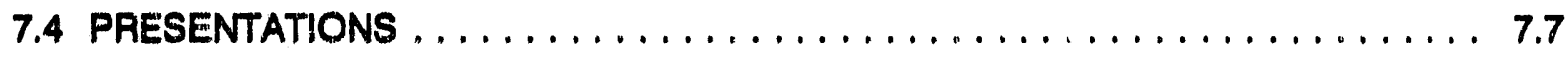

7.5 PROGRAM-RELATED PROFESSIONAL ACTIVITIES $\ldots \ldots \ldots \ldots \ldots \ldots \ldots .7$ 8.0 REFERENCES $\ldots \ldots \ldots \ldots \ldots \ldots \ldots \ldots \ldots \ldots \ldots \ldots \ldots \ldots \ldots \ldots .1$ 


\section{FIGUAES}

1.1 Management Structure and Major Communication Interfaces for

Haniord Radiological Support Services . . . . . . . . . . . . . . . . . . . . 1.2

2.1 Standard and Non-Standard Excreta Requests by Month $\ldots \ldots \ldots \ldots \ldots \ldots$

2.2 Poutine Urine Messurements Made from 1986 through $1991 \ldots \ldots \ldots$. . . . . . . 2.14

2.3 Routine in Vivo Messurements Made at the In Vivo

Radioaseay and Research Facility from 1986 through $1991 \ldots \ldots \ldots \ldots \ldots . .2 .16$

3.1 Enclosure Around the Lquid Nitrogen Tanks at $747-A$ Bullding $\ldots \ldots \ldots \ldots \ldots . \ldots 3.5$

3.2 Hemote in Vivo Counting System in 200-East Area $\ldots \ldots \ldots \ldots \ldots \ldots \ldots \ldots$

4.1 Corrected and Uncorrected Dose Response for Hantord

Automated Reader System . . . . . . . . . . . . . . . . . . . . . . . 4.8

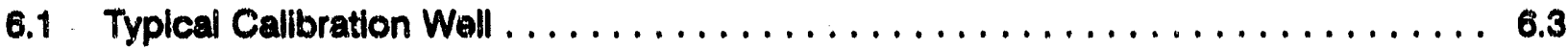

6.2 Schematic Diagram of the K-fluorescence $X$-ray Technique $\ldots \ldots \ldots \ldots \ldots \ldots . . \ldots$

6.3 Schematic of "HOG" Shield System Used for K-fluorescence

X-ray Technique ............................... 6.4

6.4 Schematic of Precision Radiation Measurement Model

LE-0.8 Low-Energy Ionization Chamber . . . . . . . . . . . . . . . . . . . . . . . . . 6.9

6.5 Placement, Removal, and Storage Assembly for the ${ }^{252} \mathrm{Cf}$

Source $D_{2} O$ Moderating Sphere . . . . . . . . . . . . . . . . . . . . 6.10 


\section{TABLES}

2.1 Emergency and Expedited Bioassay Analysis Capability Provided by the PNL Analytical Chemistry Laboratory for the Interim Period

2.2 Specified Minimum Detectable Activitjes and Screening Levels for Foutine Excreta Analyses During 1991, Interim Contracts . . . . . . . . . . . . . 2.4

2.31990 and 1991 Interim Bioassay Laboratory Activities . . . . . . . . . . . . . 2.5

2.4 Specified Minimum Detectable Activities and Screening Levels for Routine Excreta Analyses During 1991, Permanent ITAS Contract

2.5 Minimum Detectable Activities and Screening Levels for Routine In Vivo Measurements During 1991

2.6 Program Change Records for 1991

2.7 Excreta Measurements for Samples Requested During CY $1991 \ldots \ldots \ldots \ldots \ldots$

2.8 In Vivo Measurements Performed During CY 1991 and Recorded

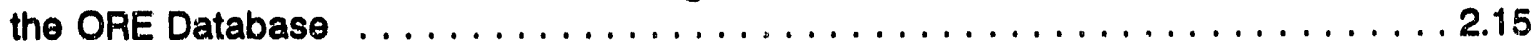

2.9 Summary of Potential Exposure Incidents During $1991 \ldots \ldots \ldots \ldots \ldots \ldots \ldots$

2.10 Comparison of Internal Exposure Incidents and Internal Exposure Dose Assessinents, $1987-1991 \ldots \ldots \ldots \ldots \ldots \ldots \ldots \ldots$

2.11 Summary of Potential Exposure Cases Identified through

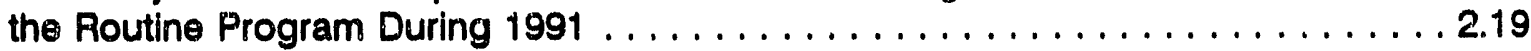

2.12 Internal Dose Status of the Hanford Work Force at 1991 Year End . . . . . . . . 2.20

2.13 Corrected Excreta Measurements for Samples Requested During CY $1990 \ldots$. . . . 2.21

3.1 Measurements Made on Hanford Personnel During $1991 \ldots \ldots \ldots \ldots \ldots \ldots \ldots$

3.2 In Vivo Measurements Made at the In Vivo Radioassay and Research

Facility from 1987 through $1991 \ldots \ldots \ldots \ldots \ldots \ldots \ldots \ldots \ldots \ldots \ldots \ldots . .2$

4.1 PNL Performance in DOELAP Testing in CY 1989 and $1991 \ldots \ldots \ldots \ldots \ldots .2$

4.2 Peisonnel Dosimeters Processed During $1991 \ldots \ldots \ldots \ldots \ldots \ldots \ldots \ldots$

4.3 Audit Dosimeters Processed During $1991 \ldots \ldots \ldots \ldots \ldots \ldots \ldots \ldots \ldots \ldots$

5.1 Portable Instrument Usage for CY $1991 \ldots \ldots \ldots \ldots \ldots \ldots \ldots \ldots \ldots \ldots$ 
6.1 Avallable Photon lsotopic Sources $\ldots \ldots \ldots \ldots \ldots \ldots \ldots \ldots \ldots \ldots \ldots$

6.2 Available $\mathrm{X}$-ray Photon Techniques $\ldots \ldots \ldots \ldots \ldots \ldots \ldots \ldots \ldots \ldots \ldots \ldots$

6.3 Calibration Performance Summary $\ldots \ldots \ldots \ldots \ldots \ldots \ldots \ldots \ldots \ldots \ldots \ldots$

7.1 Records Activity for CY $1991 \ldots \ldots \ldots \ldots \ldots \ldots \ldots \ldots \ldots \ldots \ldots \ldots \ldots$ 


\subsection{INTRODUCTION}

This annual report documents the calendar year (CY) 1991 activities of certain radiation protection sitewide services operated by Pacific Northwest Laboratory (PNL) ${ }^{(a)}$ for the U.S. Department of Energy (DOE), Richland Field Office (RL) and the Hanford contractors. The programs covered provide services in the areas of 1) internal dosimetry, 2) in vivo measurements, 3) external dosimetry, 4) instrument calibration and evaluation, 5) calibration of radiation sources traceable to the National Institute of Science and Technology (NIST), and 6) radiological records. All of these senvices fall within the purview of PNL's Health Physics Department.

While some of the programs discussed in this report are involved in activities funded by other sources, only those activities funded by RL, DOE Headquarters (HQ), and the Hanford contractors are addressed here. It should be noted that the services provided for non-RL. activities are performed only to the exient that they do not adversely affect services to DOE and its contractors; however, these services provide funds that support the overall program and reduce the costs to DOE and the Hanford contractors (Boeing Computer ServicesRichland [BCSP], the Hanford Environmental Health Foundation [HEHF], Kaiser Engineers Hanford Company [KEH], PNL, and Westinghouse Hanford Compaiily [WHC]).

Each Hanford program listed above is presented in a separate section of the report. Each major section discusses the routine program, including any significant changes and improvements; investigations, studies, and tasks performed in support of the routine program; and other prograin-related activities such as publications, presentations, professional memberships, and external professional activities, if applicable. Figure 1.1 is an organizational chart showing the PNL and DOE management structure and communication interfaces for each PNL-operated program and the DOE Safety and Environmental Division, which is responsible for PNL's services in this area.

(a) Pacific Northwest Laboratory is operated by Battelle Memorial Institute for the U.S. Department of Energy under Contract DE-AC06-76RLO 1830. 


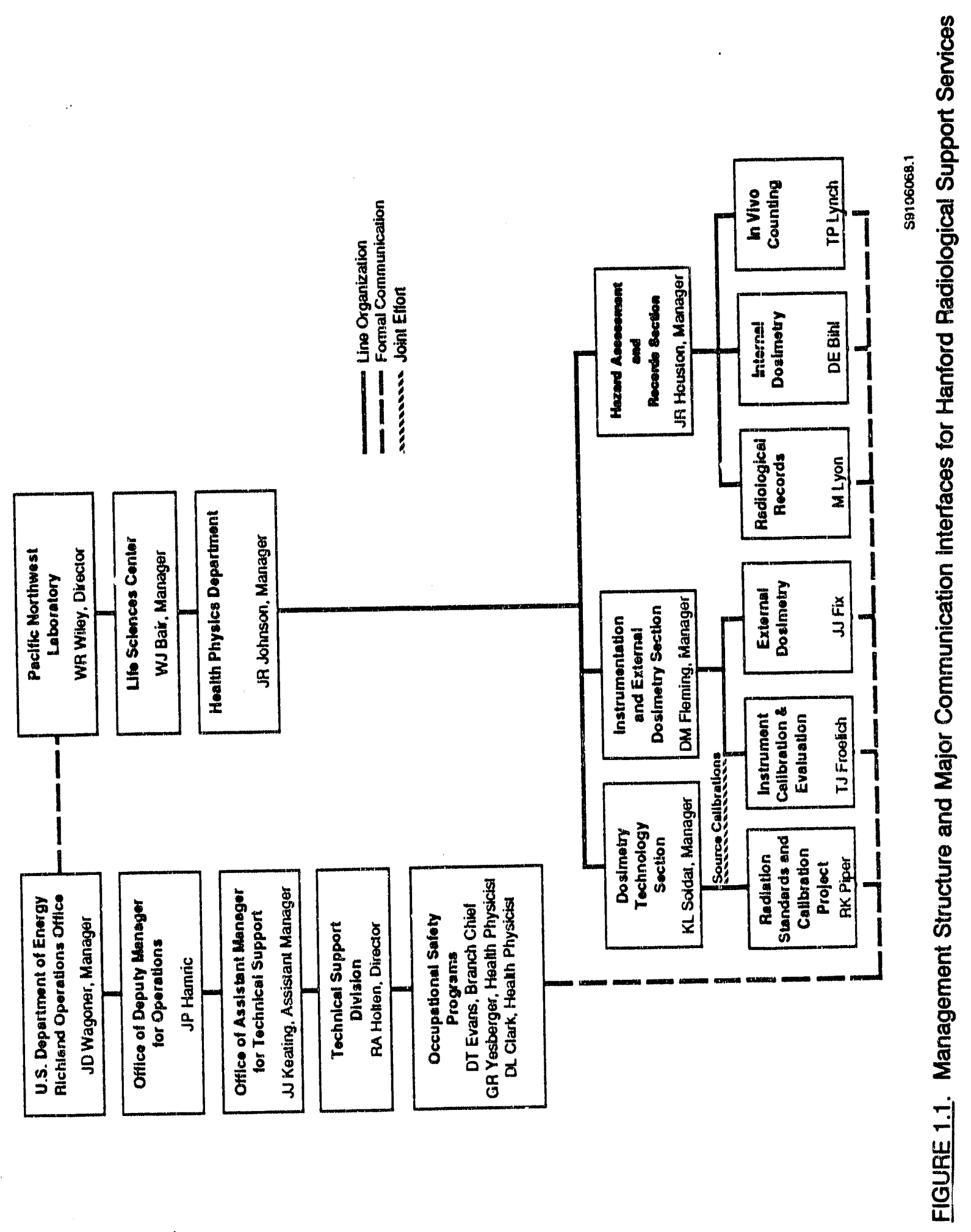




\subsection{HANFORD INTERNAL DOSIMETRY PROGRAM}

The Hanford Internal Dosimetry Program (IDP) was initiated in late 1944 to provide for the assessment and documentation of occupational doses from intakes of radionuclides at Hanford. The IDP supports Hanford radiation protection programs, as required by DOE Order 5480.11 (DOE 1988a) and the Hanford Site Services Handbook (RL 1991). The program provides the following internal dosimetry services:

- administration of a routine bioassay monitoring program

- investigation and assessment of potential internal exposures

- monitoring performance of the excreta bioassay laboratories

- selection and application of models, procedures, and practices for evaluating internal exposures

- technical support to RL and Hanford Site contractors.

In addition, the program provides a 24-hour single point of contact for technical support for radiological or hazardous chemical incidents at Hanford and in the DOE Region 8 area.

In 1991, the excreta bioassay program continued to use interim laboratories. The procurement of a new laboratory to do all excreta bioassay under a long-term contract was completed, the contract was established, and work began at the new laboratory during the last quarter of 1991.

\subsection{EXCRETA BIOASSAY PROGRAM}

Bioassay monitoring is performed regularly for workers who might inhale, ingest, or absorb radionuclides into their bodies in the course of their jobs. Because of continued use of an interim Excreta Bloassay Program plus startup of a new long-term excreta lab, the Excreta Bioassay Program is discussed separately in this year's report. Some aspects of in vivo monitoring are discussed under "Routine Internal Dosimetry Program" (Section 2.2) and further details are provided in Section 3.0, "Hanford In Vivo Measurement Program."

\subsubsection{Interim Program}

The interim Excreta Bioassay Program, which started in the summer of 1990 (see Lyon et al. 1991, pp. 2.1-2.12), continued through 1991. 


\section{Activities of the Interim Analytical Laboratories}

At the beginning of 1991, all analytical bloassay services previously offered by U.S. Testing (UST) were being provided by interim laboratories, with the exception of those provided under the contract with International Technology Analytical Services (ITAS), which did not begin until February. Los Alamos National Laboratory (LANL), Los Alamos, New Mexico provided urine sample analysis for plutonium; TMA Corporation, Richmond, California (TMANorcal) provided urinalysis for radiostrontium; PNL's Analytical Chemistry Laboratory $(A C L)$ analyzed urine samples for tritium and provided emergency bioassay analyses; and WHC's 222-S Laboratory analyzed urine samples from $\mathrm{UO}_{3}$ Plant workers for uranium. ITAS commenced analysis of fecal samples for plutonium and urine samples for isotopic uranium, americium, and uranium mass on February 1. Due to conflicting internal commitments, LANL. stopped accepting additional youtine samples in April, and was replaced by Oak Ridge National Laboratory (ORNL) in Oak Ridge, Tennesse日, and Reynolds Electric and Engineering Company (REECo) in Mercury, Nevacia. Bioassay kit handling services were provided by U.S. Dosimetry Technology (USDT). Detection levels for emergency and expedited analyses are shown in Table 2.1; contractual detection levels and screening levels for routine analyses are shown in Table 2.2 for the interim contracts.

Before submitting the first worker sample for analysis by the interim laboratories, PNL assessed each laboratory's ability to meet the performance criteria of the statement of work (SOW) by a pre-performance quality assurance audit and submission of performance evaluation samples. No samples were submitted until the laboratory could meet the performance and quality assurance requirements of the SOW.

Procedures used by interim laboratories often varied from those previously used by UST and among the laboratories themselves. Elemental uranium analysis by 222-S and ITAS was performed with laser phosphorimetry; 222-S performed minimal sample digestion, while ITAS included an ion exchange cleanup step. Radiostrontium analysis by TMA involved chemical separation and measurement of the yttrium daughter, rather than separation of the pre-existing yttrium and beta counting of the pure strontium plus freshly ingrown yttrium. Uranium and strontium interim procedures involved analysis of only a portion of the total sample. All three interim laboratories analyzing plutonium (LANL, ORNL, REECo) used limited wet acidic digestion, culminated by standard count times of nominally 1000 minutes. By contrast, both UST and ITAS permanent contract procedures involved acidic digestion and ashing, and routinely used 2500 -minute counts. 
TABLE 2.1. Emergency and Expedited Bioassay Analysis Capability Provided by the PNL Analytical Chemistry Laboratory for the Interim Period

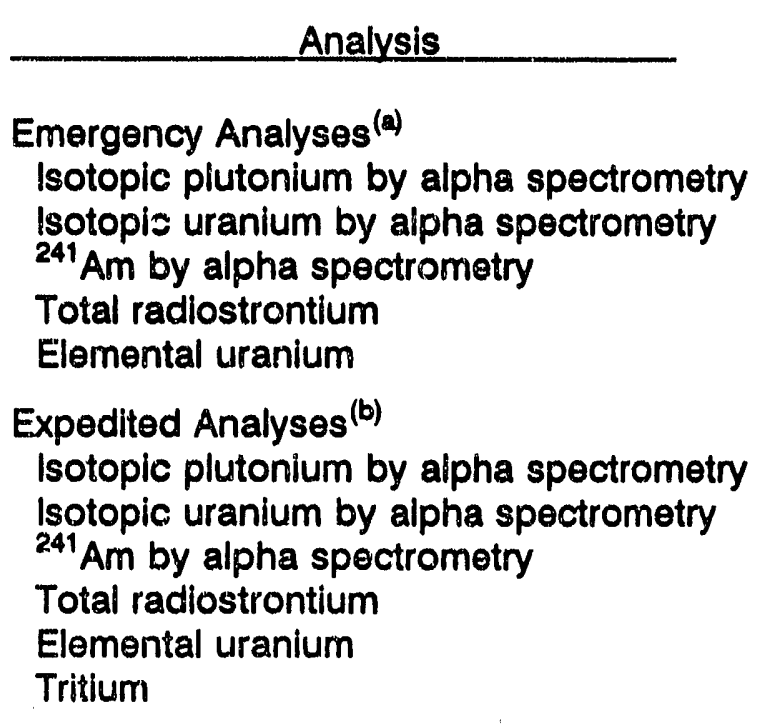

\section{Detection Level (per sample)}

\begin{tabular}{crrr}
\multicolumn{2}{c}{ Urine } & & Feces \\
& & & \\
$2.0 \mathrm{dpm}$ & & $20 \mathrm{dpm}$ \\
$2.0 \mathrm{dpm}$ & & $20 \mathrm{dpm}$ \\
$2.0 \mathrm{dpm}$ & $20 \mathrm{dpm}$ \\
200 & $\mathrm{dpm}$ & 2000 & $\mathrm{dpm}$ \\
$20 \mathrm{gg}$ & 20 & $\mu \mathrm{g}$ \\
& & & \\
$0.4 \mathrm{dpm}$ & 4 & $\mathrm{dpm}$ \\
$0.4 \mathrm{dpm}$ & 4 & $\mathrm{dpm}$ \\
$0.4 \mathrm{dpm}$ & 4 & $\mathrm{dpm}$ \\
40 & $\mathrm{dpm}$ & 400 & $\mathrm{dpm}$ \\
4 & $\mu \mathrm{g}$ & 4 & $\mu \mathrm{g}$ \\
$100 \mathrm{dpm} / \mathrm{mL}$ & - &
\end{tabular}

(a) Verbal reporting time of 10 hours after receipt of sample for plutonium and strontium and as soon as possible for the others.

(b) Verbal reporting time was 9:00 a.m. of third day after receipt of sample.

\section{Sample Collection and Shipment}

During the first 10 months of 1991, the Excreta Bioassay Program continued to use the sample kits and storage and shipping mechanisms established in 1990 . The typical urine kit consisted of a pair of 1-L high density polyethylene (HDPE) bottles in a waxed cardboard tote bearing the word "Hanfori" on two sides. The kit proved acceptable for sampling and shipping, although the lids had to be retaped after freezing if shipped offsite. Kit delivery, retrieval, and shipment was contracted to USDT from September 1990 through mid-November 1991. Samples directed to local laboratories (222-S, ACL, or ITAS) were delivered by USDT; samples for out-of-town analysis were packaged by USDT and shipped directly to the laboratories via overnight air express carrier. Samples that could not be expeditiously shipped to the corresponding processing laboratory were stored under refrigeration (tritium samples) or frozen (all others).

About 1000 samples were backlogged (i.e., in storage before shipment to a laboratory) at the beginning of CY 1990. After a slight decrease in early 1991, the backlog increased to over 1100 in June and July, due primarily to the time lag between the loss of availability of 
TABLE 2.2. Specified Minimum Detectable Activities and Screening Levels for Routine Excreta Analyses During 1991, Interim Contracts

LANL
TMANNorca

ITAS-RI

PNL-ACL

WHC 222-S

ORNL

REECO

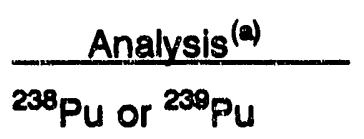

Radiostrontium (as ${ }^{80} \mathrm{Sr}$ )

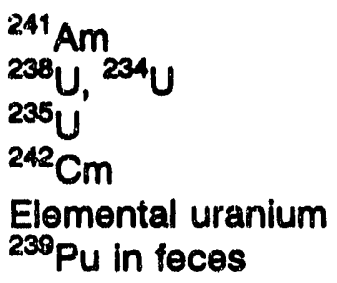

Tritium

Elemental uranium (quick analycis procedure [QUS])

$$
{ }^{238} \mathrm{Pu} \text { or }{ }^{239} \mathrm{Pu}
$$

\section{Contractual $M A^{(b, c)}$ \\ $0.03 \mathrm{dpm}$ \\ $30 \mathrm{dpm}$}

$0.03 \mathrm{dpm}$

$0.03 \mathrm{dpm}$

$0.03 \mathrm{dpm}$

$0.03 \mathrm{dpm}$

$0.2 \mu \mathrm{g}$

$0.2 \mathrm{dpm}$

$10 \mathrm{dpm} / \mathrm{mL}$

$0.5 \mu \mathrm{g}$

$0.03 \mathrm{dpm}$

$0.03 \mathrm{dpm}$
Screoning LeVel and Sampling Frequency $(0$, d)

$0.015 \mathrm{dpm}(\mathrm{A})$

$26 \mathrm{dpm}(\mathrm{A})$

$0.015 \mathrm{dpm}(\mathrm{A})$

$0.15 \mathrm{dpm}(A)^{(0)}$

$0.015 \mathrm{dpm}(\mathrm{A})$

$0.015 \mathrm{dpm}(\mathrm{A})$

$0.2 \mu g(A)^{(\theta)}$

$2.0 \mathrm{dpm}(A)$

$80 \mathrm{dpm} / \mathrm{mL}(\mathrm{M})$

$11 \mu \mathrm{g}(\mathrm{BW})$

or $4 \mu g(M)$

$0.015 \mathrm{dpm}(\mathrm{A})$

$0.015 \mathrm{dpm}(\mathrm{A})$

(a) Analysis of urine samples unless otherwise indicated.

(b) Specified minimum detectable activity (MDA) based on Type I and Type II errors of 5\% as described in the respective statements of woik for each laboratory. (A copy of each SOW is available in the Hanford Radiation Protection Historical Files.)

(c) Amount per total sample volume unless otherwise indicated.

(d) Investigation of a potential internal exposure is performed when this value is exceeded. Routine bioassay monitoring frequency: A-annual, BW-biweekly, M-monthly.

(e) Upper level of expected environmentally derived uranium in urine for the Hanford region.

LANL services (last sample shipment was in April 1991) and the startup of processing of Hanford plutonium samples at ORNL and REECo. The tritium backlog was eliminated in January 1991; QUS in March; isotopic uranium (IU), natural uranium, americium-curium in March; and strontium-90 in June. The plutonium backlog was distributed to the processing laboratories by mid-December 1991. Results for samples submitted during the interim contract were received by March 4, 1992. A summary of interim laboratory activities is provided in Table 2.3. 
TABLE 2.3. 1990 and 1991 Interim Bioassay Laboratory Activities

\begin{tabular}{|c|c|c|c|c|c|}
\hline Laboratury & $\begin{array}{l}\text { Performance } \\
\text { Test Samples } \\
\text { Submitted } \\
\end{array}$ & $\begin{array}{l}\text { First Worker } \\
\text { Samples } \\
\text { Submitted }\end{array}$ & $\begin{array}{c}\text { Samples } \\
\text { in } \\
\text { CY } 1990\end{array}$ & $\begin{array}{c}\text { Samples } \\
\text { in } \\
\text { cy } 1991 \\
\end{array}$ & $\begin{array}{l}\text { Date Last } \\
\text { Results } \\
\text { Received } \\
\end{array}$ \\
\hline LANL & $9 / 6 / 90$ & $9 / 20 / 90$ & 1184 & 1044 & $10 / 29 / 91$ \\
\hline TMANorcal & $10 / 10 / 90$ & $11 / 9 / 90$ & 300 & 1991 & $12 / 6 / 91$ \\
\hline ITAS & $12 / 6 / 90$ & $2 / 1 / 91$ & 0 & $1252^{(4)}$ & $3 / 4 / 91$ \\
\hline ACL/PNL & $10 / 10 / 90$ & $10 / 29 / 90$ & 130 & 792 & $12 / 4 / 91$ \\
\hline 222-SMHC & $9 / 28 / 90$ & $10 / 24 / 90$ & 119 & 1145 & $12 / 2 / 91$ \\
\hline ORNL & $5 / 29 / 91$ & $7 / 23 / 91$ & 0 & 1261 & $2 / 28 / 92$ \\
\hline REECo & $\begin{array}{l}6 / 10 / 91 \\
7 / 11 / 91\end{array}$ & $8 / 5 / 91$ & 0 & 883 & $3 / 4 / 92$ \\
\hline
\end{tabular}

(a) Total includes 176 samples collected during the interim period but redirected to ITAS after start of permanent contract, and processed under permanent contract requirements.

From the onset of the interim Excreta Bioassay Piogram, some aspects of the previous program were modified. No laboratory was found to perform the sequential analyses that were available under the UST contracts. As a result, workers were required to provide individual samples for each nuclide requested. It became particularly difficult to successfully collect termination samples for multiple nuclides. All processing was specified as routine, with the exception of emergency or expedited processing at ACL; the latter were reserved for incidents only. Because USDT was not contracted, nor had means, to determine sample volume, the minimum acceptable volume requirements based on kit and priority codes were not in effect. The capabilities of ordering sequential analyses on single samples and rejecting samples because of insufficient volume were both reinstated with the new long-term contract.

Sample requests can be categorized as standard or non-standard. Standard requests are those which are generated by the Occupational Radiation Exposure system (ORE) database from a pre-determined, routine schedule (for instance, a worker may be scheduled for an annual sample collected every April). These requests are downloaded from ORE and electronically transferred to the lab just before the start of each month. All other requests are considered non-standard requests. These are manually requested by the contractors to IDP; IDP initiates the paperwork and transfers the request to Radiological Records; Radiological Records loads the request into ORE and then has the computer transfer the request to the lab, a much more labor-intensive process. Figure 2.1 shows the monthly distribution of 


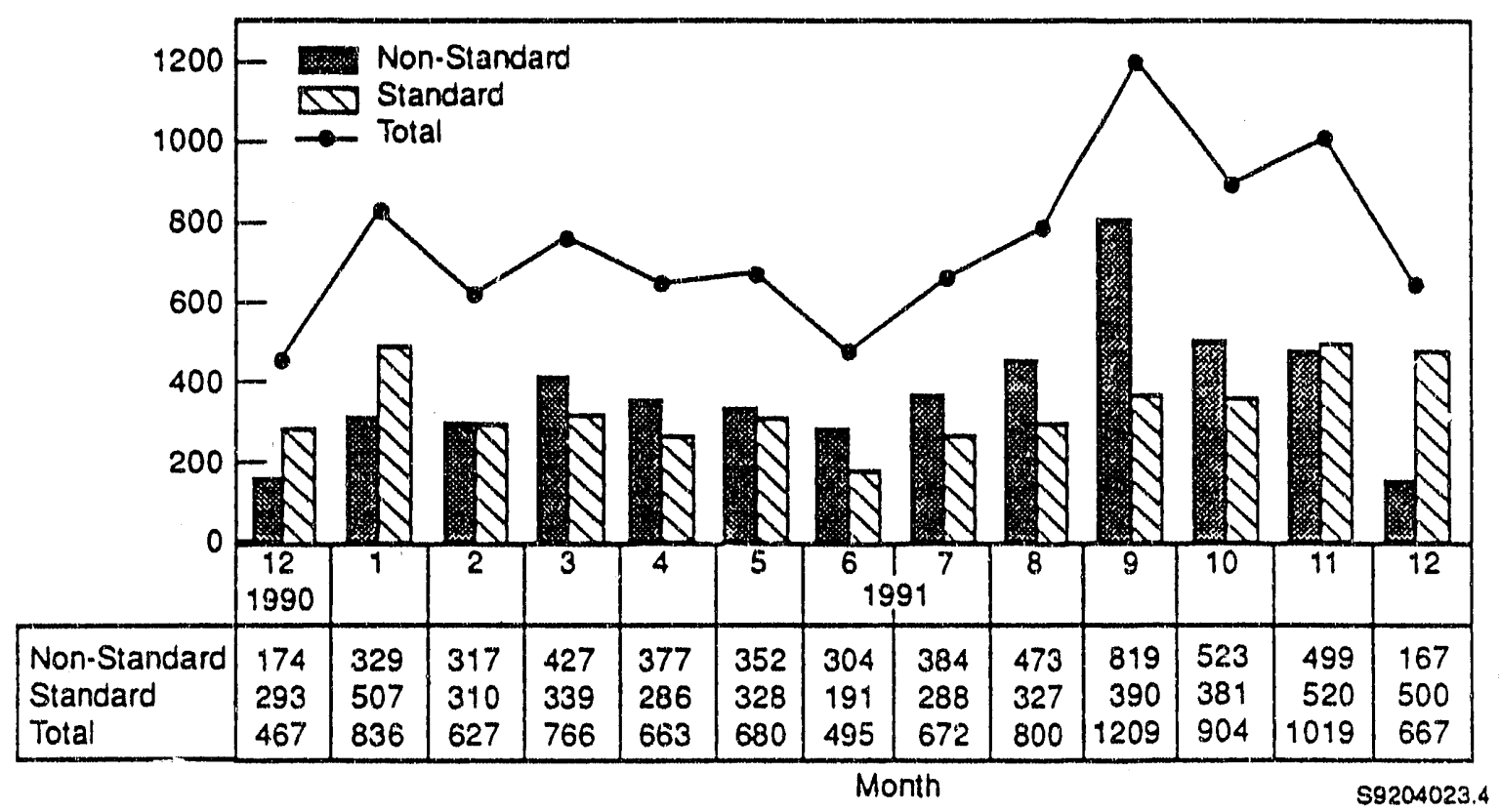

FiGURE 2.1. Standard and Non-Standard Excreta Requests by Month

standard and non-standard requests for 1991. The plots begin with December 1990 because the standard requests downloaded in December represent samples to be collected in January. The rise in non standard requests starting in September was driven by an increase in termination samples resulting from the close-out of several projects at the end of the fiscal year. Overall, non-standard requests in 1991 increased over previous years.

\subsubsection{Now Long-Term Contract}

After the UST contract was terminated on June 1, 1990, PNL began the process of reprocuring radiochemical analyses of bioassay samples for the Hanford Site. A Request for Proposal, specifying the requirements for performance of bioassay analytical services, was sent to many potential offerors. Four laboratories submitted proposals and the source evaluation team chose ITAS as the new bioassay analytical laboratory. The contract was awarded October 15, 1991, and the first samples were submitted October 22, 1991. ITAS is now providing the full range of bloassay analytical services previously provided by UST. Table 2.4 provides the contractual MDAs and screening levels applied to the new contract. 
TABLE 2.4. Specified Minimum Detectable Activities and Screening Levels for Routine Excreta Analyses During 1991, Permanent ITAS Contract

\begin{tabular}{|c|c|c|}
\hline Analysis ${ }^{(a)}$ & $\begin{array}{l}\text { Contractual } \\
\mathrm{MDA}^{(b, w)} \\
\end{array}$ & $\begin{array}{l}\text { and Sampling } \\
\text { Frequency }(0, d)\end{array}$ \\
\hline${ }^{238} \mathrm{Pu},{ }^{230} \mathrm{Pu}$ & $0.02 \mathrm{dpm}$ & $0.01 \mathrm{dpm}(\mathrm{A})$ \\
\hline \multirow[t]{2}{*}{${ }^{80} \mathrm{Sr}$} & $10 \mathrm{dpm}$ & $26 \mathrm{dpm}(\mathrm{A})$ \\
\hline & & $11 \mathrm{dpm}(\mathrm{BE})$ \\
\hline${ }^{234} U,{ }^{238} U$ & $0.02 \mathrm{dpm}$ & $0.15 \mathrm{dpm}(A)^{(0)}$ \\
\hline${ }^{235} \mathrm{U}$ & $0.02 \mathrm{dpm}$ & $0.01 \mathrm{dpm}(\mathrm{A})$ \\
\hline${ }^{241} \mathrm{Am},{ }^{242} \mathrm{Cm}$ & $0.02 \mathrm{dpm}$ & $0.01 \mathrm{dpm}(\mathrm{A})$ \\
\hline Elemental U & $0.06 \mu \mathrm{g}$ & $0.2 \mu g(A)^{(0)}$ \\
\hline Elemental U (QUS) & $0.5 \mu g$ & $\begin{array}{cc}11 \mu g & (B W) \\
4 & \mu g\end{array}$ \\
\hline Tritium & $20 \mathrm{dpm} / \mathrm{mL}$ & $80 \mathrm{dpm} / \mathrm{mL} / \mathrm{M}$ \\
\hline
\end{tabular}

(a) Analysis of urine samples unless otherwise indicated.

(b) Specified minimum detectable activity (MDA) based on Type I and Type II érrors of $5 \%$, as described in the respective SOWs for each laboratory. (A copy of each SOW is available in the Hanford Padiation Protection Historical Files.)

(c) Amount per total sample volume unless otherwise indicated.

(d) Investigation of a potential internal exposure is performed when this value is exceeded. Routine bioassay monitoring frequency: Aannual, BE-biennial, BW-biweekly, M-monthly, Q-quarterly.

(e) Upper level of expected environmentally derived uranium in urine for the Hanford region.

\subsubsection{Quality Control Audit Program}

About 380 .samples with known amounts of various radionuclides (blanks and spikes) were submitted to the seven analytical laboratories performing analytical bioassay analyses for PNL to check the accuracy, precision, and detection levels of their urinalyses. The number of laboratories requiring monitoring put a significant strain on the program's ability to produce sufficient blind audit samples. 
Urine collected from nonexposed PNL employees was prepared as blank and spiked samples by the chemistry laboratory in the 325 Bullding by PNL's ACL, according to the directions given by IDP. Most samples were submitted as double blind siamples, I.e., they were scheduled with and collected by the interim sample transfer contractor USDT as if they wore personnel samples. Other samples were subrnitted openly as audit samples (single blind). Analyses for ${ }^{230} \mathrm{Pu}_{1}{ }^{230} \mathrm{Pu},{ }^{241} \mathrm{Am},{ }^{80} \mathrm{Sr}$, trittum, and uranium via twc different procedures were tested. This external audit sample program provided a check on the laboratories' own internal quality control (QC) programs. In addition to the QC samples submitted by PNL, the labolatories were also required to conduct their own QC program and submit the results of analyses to PNL.

The results of the external audit program were generally the same as for the laboratories' Internal QC program. The laboratories met all precision and bias criteria for which adequate samples were analyzed (i.e., greater than 15). The minimum detectable amount criterion was met by all laboratories except for LANL's analysis of ${ }^{230} \mathrm{Pu}$ in urine and ITAS isotopic analysis of uranium in urine. The problem with the uranium analysis may be explained by the interference of ambient levels of naturally cccurring uranium in urine. The blind audit blank samples submitted by PNL indicated that LANL did meet the ${ }^{239} \mathrm{Pu}$ criterion for MDA, but LANL's internal samples did not. In any case, the calculated MDA was near the required detection level of $0.03 \mathrm{dpm}$ per sample, and the failure may have been a result of uncertainty in the estimate.

\subsubsection{Omenn Committee Investigation}

The Omenn Committee, established by the Director of PNL in 19510 (see Lyon et al. 1991), concluded its investigation on the validity of the excreta sample results produced by UST trom 1934 to 1990 . $^{(\mathrm{a})}$ The Omenn Comrnittee found that UST's peiformance in the bloassay program was, with minor exceptions, in cornpliance with conticctual requirements and was technically competent according to every measure considerecl. The Committee also found "aredible the conclusion that (with a few specific exceptions ... which tend to support the basic integrity of the UST operation) UST QC results are consistent with PINL audit sample results."

The Committee made two suggestions concerning oversight of laboratory performance. One suggestion was to increase the number of audit samples to about: 60 samples per analysis type to obtain $295 \%$ confidence. This could be spread over two-year periods. The

(a) Omenn, G. S., G. van Belle, D. A. Kalman, and M. O'Brien. 1991. "Retrospective Evaluation of Caca Submitted by U.S. Testing in Support of the linternal Bloassiay Program Operated by Battelle, Pacific Nortiwwest Laboratories 1\$83-1990." Available from Radiation Protection Historical Files, Pacific Northwest Laboratory, Richland, Washington. 
second suggestion was to tie QC samples to specific batches and establish criteria to validate each batch.

\subsection{ROUTINE INTERNAL DOSIMETRY PROGRAM}

Changes to the Excreta Bioassay Program, including MDAs and follow-up levels, were given in Tables 2.2 and 2.4. The In Vivo Bloassay Program was more stable during 1991. The MDAs and follow-up levels for in vivo measurements are listed in Table 2.5; they are unchanged from 1990 values.

Operation of the IDP is recorded in several documents. The technical aspects of internal dose calculations are established in the Technical Basis for Internal Dosimetry at Hanford (Sula, Carbaugh, and Bihl 1991), the protocols and practices for operation of the

TABLE 2.5. Minimum Detectable Activities and Screening Levels for Routine In Vivo Measurements During 1991

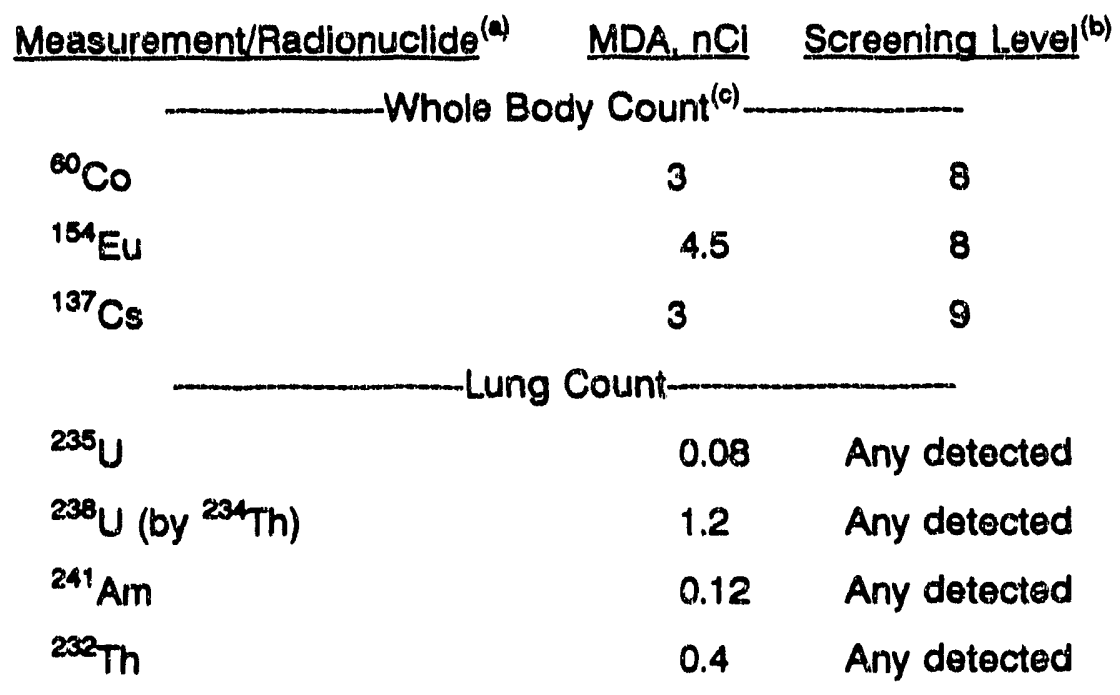

(a) For selected radionuclides. Detection of radionuclides not listed resulted in follow-up.

(b) Level for which an investigation of internal exposure was considered. Any detected activity above background was reported to IDP.

(c) MDAs apply to the preview counter only; much lower MDAs were obtained using the germanium array when activity was first detected using the preview counter. 
program and coordination with the Hanford Site contractors are established in the Hanford Internal Dosimetry Program Manual, ${ }^{(a)}$ the contractual agreements with the various excreta labs are established by statements of work with each lab, and the practices and technical aspects of operation of the In Vivo Measurement Program are established in the Whole Body Counting Manual. ${ }^{\text {(b) }}$ In addition, during 1991, work was nearly completed on establishing agreement between the IDP and the In Vivo Measurement Program on practices and protocols not covered in the Whole Body Counting Manual; the agreement will be issued as an SOW for the In Vivo Measurement Program. Individual assessinents of internal dose are documented in each individual's file in the Hanford Radiological Records Program (HRRP) microfilm files. Bloassay measurement results are maintained in the ORE database operated by the HRRP.

Small-scope changes to the practices or technical aspects of either the IDP or In Vivo Measurement Program are documented by Program Change Records. Ultimately, these changes become incorporated in the various documentation mentioned above. The Program Change Record identifies the change, its effecti: date, and the reasons and impacts of the change. A copy of the Program Change Record is placed in the Hanford Radiation Protection History Files. The Program Change Records issued in 1991 are listed in Table 2.6.

\subsubsection{Testing and Implementation of the Code for !nternal Dosimetry}

The Code for Internal Dosimetry (CINDY) (Strenge et al. 1990a and 1990b) was extensively tested and accepted for use in bioassay analysis and internal dose calculation. The code was found to be comprehensive, user-friendly, well-documented, and generally in agreement with results obtained for dose, organ retention, and excretion using the methods of the Technical Basis for Internal Dosimetry at Hanford (Sula, Carbaugh, and Bihl 1991). Some problems were noted with the code, including a significant error in the tritium calculations and an inability to calculate ${ }^{241} \mathrm{Pu}$ intake based on ${ }^{241} \mathrm{Am}$ content in the lung. (These problems were reported to the authors.) CINDY was adopted as one tool for use by the IDP, but does not totally replace other codes or methods already in use. Dosimetry evaluation staff were trained in the use of the code. A letter report was issued summarizing the testing and training, and a copy of it was placed in the Hanford Re fiation Protection Historical Files. ${ }^{(0)}$

(a) Pacific Northwest Laboratory (PNL). Hanford Internal Dosimetry Program Manual (Internal Manual). PNL-MA-572, PNL, Richland, Washington.

(b) Pacific Northwest Laboratory (PNL). Whole Body Counting Manual (Internal Manual). PNL-MA-574, PNL, Richland, Washington.

(c) Letter to Distribution from D. E. Bihl, dated September 30, 1991, "Training and Testing of the Internal Dosimetiy Code, CINDY," and attached report, Verification and Other Tests Toward Incorporation of CINDY for Use in the Hanford Internal Dosimetry Program, D. E. Bihl, E. H. Carbaugh, and J. A. MacLellan. Copy in the Radiation Protection Historical File, Pacific Northwest Laboratory, Richland, Washington. 
TABLE 2.6. Program Change Records for 1991

\begin{tabular}{|c|c|c|c|}
\hline $\begin{array}{l}\text { PCR } \\
\text { No. }\end{array}$ & Effective Date & Title & $\begin{array}{l}\text { Affected Areas } \\
\text { of Program }\end{array}$ \\
\hline $91-001$ & $01-22-91$ & $\begin{array}{l}\text { Change in the Nuclide } \\
\text { Library for Routine l.ung } \\
\text { Calculations }\end{array}$ & $\begin{array}{l}\text { Eliminated Eu and Ce from } \\
\text { routine lung measurement } \\
\text { calculations }\end{array}$ \\
\hline $91-002$ & $01-01-91$ & $\begin{array}{l}\text { Dose Assessment (10 mrem) } \\
\text { Screening Level for QUS } \\
\text { Bioassay }\end{array}$ & $\begin{array}{l}\text { Established protocol for } \\
\text { issuing dose assessment } \\
\text { based on annual review of } \\
\text { chronic exposure data }\end{array}$ \\
\hline $91-003$ & $02-01-91$ & $\begin{array}{l}\text { High Flag on Bioassay } \\
\text { Results }\end{array}$ & $\begin{array}{l}\text { ORE database high flag wil } \\
\text { be set to " }+" \text { for all results } \\
\text { greater than natural } \\
\text { background }\end{array}$ \\
\hline $91-004$ & 04-18-91 & $\begin{array}{l}{ }^{137} \text { Cs Screening Levels and } \\
{ }^{137} \text { Cs Questionnaire }\end{array}$ & $\begin{array}{l}\text { Clarified response to } \\
\text { detection of }{ }^{137} \mathrm{Cs} \text { and } \\
\text { provided for additional data } \\
\text { collection }\end{array}$ \\
\hline $91-005$ & $09-26-91$ & $\begin{array}{l}\text { In Vivo Bloassay for Short- } \\
\text { term Workers }\end{array}$ & $\begin{array}{l}\text { Provided for use of } 1000- \\
\text { second lung counts for } \\
\text { some applications }\end{array}$ \\
\hline $91-006$ & 10-15-91 & Dose Assessment Flowcharts & $\begin{array}{l}\text { Provided guidance for } \\
\text { resolving ambiguous } \\
\text { sources of low-level interna } \\
\text { dose }\end{array}$ \\
\hline
\end{tabular}

\subsubsection{Revision of the Technical Basis for Internal Dosimetry at Hanford}

A complete revised version of the Technical Basis for Internal Dosimetry at Hanford was issued in July 1991 . The revision was prompted by the desire to have certain additional information readily available for routine use in dose assessment and bioassay program design. Some changes in the presentation of information were also made to make the document easier to use, particularly in light of proposed DOE implementation guides and performance standards for internal closimetry. The biokinetic and dosimetric models were not changed from those described in the original issue of the document. 


\subsubsection{Bloassay Criteria for Environmental Restoration Workers}

A letter report ${ }^{(a)}$ to WHC provided a method for identifying those workers performing environmental restoration and remediation work who should be placed on a bloassay program. The work typically involves excavation of potentially contaminated soils at solid or liquid waste disposal sites. Soll contamination criteria (in terms of activity concentration of soil) were based on acute or chronic intake scenarios that might result in an intake of $2 \%$ of the Annual Limit on Intake for pertinent radionuclides. These criteria were proposed as a basis for comparing soil sample results obtained from pre-job or on-the-job samples. The soil contamination criteria ranged from $2 \mathrm{pCl} / \mathrm{g}$ for ${ }^{232} \mathrm{Th}$ to $400,000 \mathrm{pCl} / \mathrm{g}$ for ${ }^{137} \mathrm{Cs}$. Two other notable criterla were $20 \mathrm{pCl} / \mathrm{g}$ for $\mathrm{Pu}-\alpha$, and $70 \mathrm{pCi} / \mathrm{g}$ for total uranium. The criterion for tritium in groundwater was calculated to be $1000 \mu \mathrm{Ci} / \mathrm{L}$, which is higher than any observed tritium levels in Hanford groundwater. Thus, it was concluded that there was no need for tritium monitoring of environmental restoration workers. A copy of the report was placed in the Hanford Radiation Protection Historical Files.

\subsection{MONITORING AND ASSESSMENT ACTIVITIES}

During 1991, 20,777 in vivo and excreta bioassay measurements were performed for Hanford activities, excluding cancellations, no-samples, and samples without valid resulis. Of these, over $98 \%$ were classified as routine (including measurements on visitors), with about $1 \%$ each due to potential or confirmed intake follow-up measurements and special purpose measurements.

Table 2.7 summarizes the excreta measurements requested in CY 1991 for complete results received from the labs as of March 4, 1992. Most noteworthy was the marked increase in analyses performed for tritium and uranium, plus a substantial increase in plutonium analyses, as depicted in Figure 2.2. In addition, a total of 941 excreta sample requests representing 955 determinations were designated as no-result samples for 1991 . Unsuccessful sample collections were attributed to the following: no sample received ( $46 \%$ of total unsuccessful collections); lost container (46\%); insufficient sample volume (3\%); and lost-in-lab (5\%). In vivo measurements made in CY 1991 are summarized in Table 2.8. Not included in these figures are the 555 whole body, 8 chest, and 2 wound measurements that were declared invalid due to radon interference $(75 \%)$, preliminary count (20\%), equipment failure (3\%), medically administered radionuclide presence (1\%), and other miscellaneous reasons (1\%).

(a) Letter to T. J. Kelly (WHC) from E. H. Carbaugh, dated December 3, 1991, "Bioassay Criteria for Environmental Restoration Workers," and enclosed report by $E$. $H$. Carbaugh, dated November 1991, of the same title. Copy in the Radiation Protection Historical File, Pacific Northwest Laboratory, Richland, Washington. 
TABLE 2.7. Excreta Measurements for Samples Requested During CY 1991

\begin{tabular}{|c|c|c|c|c|c|}
\hline Type/Peason & DOE & $\mathrm{KEH}$ & PNL & WHC & TOTAL \\
\hline $\begin{array}{l}{ }^{3} \text { H-urine } \\
\text { Routine schedule(a) } \\
\text { Special request } \\
\text { Intake follow-up }^{(\theta)}\end{array}$ & $\begin{array}{l}0 \\
0 \\
0\end{array}$ & $\begin{array}{r}411 \\
1 \\
1\end{array}$ & $\begin{array}{r}454 \\
1 \\
1\end{array}$ & $\begin{array}{r}85 \\
3 \\
0\end{array}$ & $\begin{array}{r}950 \\
5 \\
2\end{array}$ \\
\hline $\begin{array}{l}{ }^{80} \text { Sr-urine } \\
\text { Routine schedule } \\
\text { Special request } \\
\text { Intake follow-up }\end{array}$ & $\begin{array}{r}21 \\
0 \\
0\end{array}$ & $\begin{array}{r}469 \\
0 \\
0\end{array}$ & $\begin{array}{r}19 \\
1 \\
0\end{array}$ & $\begin{array}{r}1034 \\
6 \\
6\end{array}$ & $\begin{array}{r}1543 \\
7 \\
6\end{array}$ \\
\hline $\begin{array}{l}\text { Uranium-urine } \\
\text { Routine schedule } \\
\text { Special request } \\
\text { Intake follow-up }\end{array}$ & $\begin{array}{l}4 \\
0 \\
0\end{array}$ & $\begin{array}{r}528 \\
0 \\
0\end{array}$ & $\begin{array}{r}200 \\
0 \\
0\end{array}$ & $\begin{array}{r}1003 \\
6 \\
10\end{array}$ & $\begin{array}{r}1735 \\
6 \\
10\end{array}$ \\
\hline $\begin{array}{l}\text { Plutonium-urine } \\
\text { Routine schedule } \\
\text { Special request } \\
\text { Intake follow-up }\end{array}$ & $\begin{array}{r}30 \\
0 \\
0\end{array}$ & $\begin{array}{r}672 \\
0 \\
11\end{array}$ & $\begin{array}{r}273 \\
4 \\
10\end{array}$ & $\begin{array}{r}2061 \\
54 \\
26\end{array}$ & $\begin{array}{r}3036 \\
58 \\
47\end{array}$ \\
\hline $\begin{array}{l}\text { Other TAU-urine } \\
\text { Routine schedule } \\
\text { Special request } \\
\text { intake follow-up }\end{array}$ & $\begin{array}{l}0 \\
0 \\
0\end{array}$ & $\begin{array}{l}0 \\
0 \\
0\end{array}$ & $\begin{array}{r}22 \\
0 \\
0\end{array}$ & $\begin{array}{l}6 \\
0 \\
0\end{array}$ & $\begin{array}{r}28 \\
0 \\
0\end{array}$ \\
\hline $\begin{array}{l}\text { Plutonium-focal } \\
\text { Routine schedule } \\
\text { Special request } \\
\text { Intake follow-up }\end{array}$ & $\begin{array}{l}0 \\
0 \\
0\end{array}$ & $\begin{array}{l}0 \\
0 \\
6\end{array}$ & $\begin{array}{l}0 \\
0 \\
1\end{array}$ & $\begin{array}{l}0 \\
1 \\
6\end{array}$ & $\begin{array}{r}0 \\
1 \\
13\end{array}$ \\
\hline${ }^{90}$ Sr-fecal & 0 & 0 & 0 & 0 & 0 \\
\hline Analyses Totals & 55 & 2099 & 986 & 4307 & 7447 \\
\hline $\begin{array}{l}\text { Recounts } \\
\text { Plutonium - urine } \\
{ }^{80} \mathrm{Sr} \text { - urine } \\
{ }^{3} \mathrm{H} \text { - urine } \\
\text { Uranium - urine }\end{array}$ & $\begin{array}{l}0 \\
0 \\
0 \\
0\end{array}$ & $\begin{array}{l}1 \\
4 \\
7 \\
2\end{array}$ & $\begin{array}{l}9 \\
0 \\
0 \\
0\end{array}$ & $\begin{array}{r}37 \\
7 \\
1 \\
2\end{array}$ & $\begin{array}{r}47 \\
11 \\
8 \\
4\end{array}$ \\
\hline
\end{tabular}

(a) Routine measurements include those with reason codes of baseline, beginning work, new hire, routine, ending work, and termination.

(b) Special measurements include those with reason codes of contractor request, evaluator request, and special study.

(c) Intake follow-up measuremerits include those with reason codes of incident, investigate high routine, and follow up. 


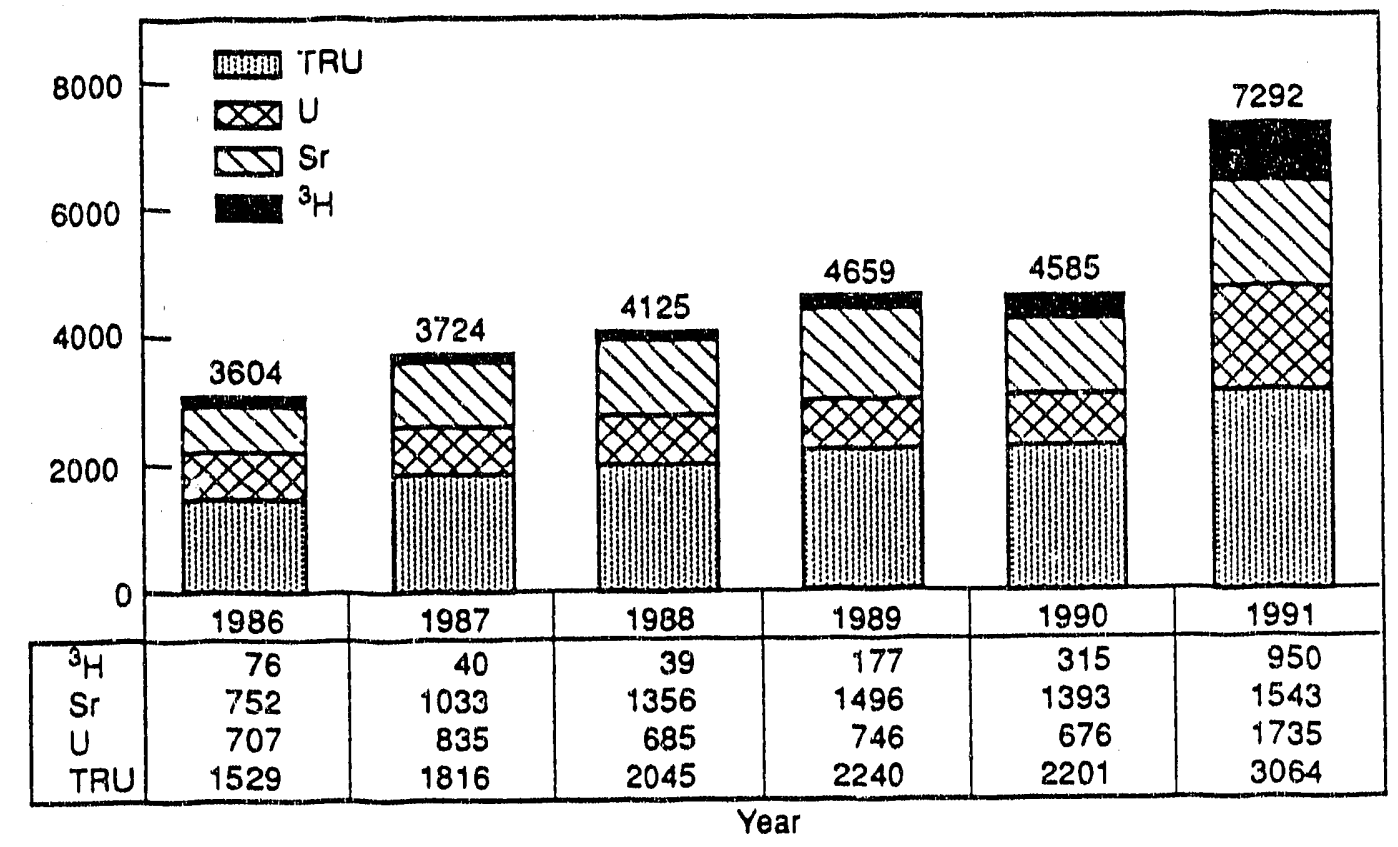

FIGURE 2.2. Routine Urine Measurements Made from 1986 through 1991

The demand for bioassay measurements shifted somewhat in 1991. Overall, itio total number of measurements increased by $13 \%$ over last year. In vivo measurements continued at about the same rate as in 1990 (se日 Figure 2.3), despite a couple of very heavy months. However, excreta results jumped by over $50 \%$ compared to 1990 , mostly because of a $56 \%$ increase in routine urine measurements. This increase was probably caused by expanding use of the Radiation Area Management system by WHC, which requires that all bioassay requirements are met before a worker can enter a radiation zone.

During 1991, 15 potential internal exposure incidents involving 30 workers were identified through workplace monitoring. Of these workers, no confirmation of intake was determined for 20 workers, and intakes were confirmed for 10 workers. Of the latter, only 1 worker incurred an intake resulting in a 50-year committed effective dose equivalent exceeding $100 \mathrm{mrem}$. The radionuclides and groups involved included ${ }^{137} \mathrm{Cs}$ and $/ 0{ }^{90} \mathrm{Sr}$ (4 incidents with 8 workers), TRU (8 incidents with 19 workers), tritium ( 1 incident with 1 worker), ${ }^{60} \mathrm{Co}$ ( 1 incident with 1 worker), and $U$ (1 incident with 1 worker). Table 2.9 shows the incident breakdown by contractor, area, and facility. Trends for the last 5 years are included in Table 2.10. 
TABLE 2.8. In Vivo Measurements Performed During CY 1991 and Recorded in the ORE Database

\begin{tabular}{|c|c|c|c|c|c|}
\hline Type/Reason & DOE & KEH & PNL & WHC & TOTAL \\
\hline $\begin{array}{l}\text { Whole body count } \\
\text { Routine schedule } \\
\text { Special request } \\
\text { Intake follow-up } \\
\text { Visitors }\end{array}$ & $\begin{array}{r}158 \\
0 \\
0 \\
216\end{array}$ & $\begin{array}{r}1246 \\
6 \\
8 \\
1\end{array}$ & $\begin{array}{r}1497 \\
5 \\
0 \\
9\end{array}$ & $\begin{array}{r}7064 \\
17 \\
22 \\
380\end{array}$ & $\begin{array}{r}9965 \\
28 \\
30 \\
606\end{array}$ \\
\hline Total & 374 & 1261 & 1511 & 7483 & 10629 \\
\hline $\begin{array}{l}\text { Chest count } \\
\text { Routine schedule } \\
\text { Special request } \\
\text { Intake follow-up } \\
\text { Visitors }\end{array}$ & $\begin{array}{l}8 \\
0 \\
0 \\
0\end{array}$ & $\begin{array}{r}707 \\
1 \\
14 \\
0\end{array}$ & $\begin{array}{r}317 \\
1 \\
11 \\
0\end{array}$ & $\begin{array}{r}1517 \\
6 \\
51 \\
5\end{array}$ & $\begin{array}{r}2549 \\
8 \\
76 \\
5\end{array}$ \\
\hline Total & 8 & 722 & 329 & 1579 & 2638 \\
\hline $\begin{array}{l}\text { Special counts } \\
\text { Hand/wound } \\
\text { Head } \\
\text { Other (a) }\end{array}$ & $\begin{array}{l}0 \\
1 \\
?\end{array}$ & $\begin{array}{l}0 \\
0 \\
0\end{array}$ & $\begin{array}{l}0 \\
8 \\
8\end{array}$ & $\begin{array}{r}13 \\
22 \\
9\end{array}$ & $\begin{array}{l}13 \\
31 \\
19\end{array}$ \\
\hline Total & 3 & 0 & 16 & 44 & \\
\hline
\end{tabular}

(a) Other counts would include any special organ count such as liver, kidney, or thyroid.

Table 2.11 shows internal dose assessments in 1991 resulting from high routine bioassay results, i.e., those not associated with known incidents or potential chronic exposure situations, and exceeding the criteria for investigation. Internal doses were assessed for the following radionuclides or groups: TRU (29 cases), ${ }^{137} \mathrm{Cs}$ and/or ${ }^{90} \mathrm{Sr}$ (2 cases), uranium ( 37 cases), and tritium (1 case). Of these, 66 cases received no internal dose, 1 case received a 50-year committed effective dose equivalent less than $100 \mathrm{mrem}$, and 2 cases received 50-year committed effective dose equivalents greater than 100 rem. These numbers are generally less than those for 1990, as shown in Table 2.10.

Potential chronic intake cases (also shown in Table 2.10) involved tritium (4 cases) and uranium (26 cases). Chronic intake assessments were not performed for workers exposed to soluble uranium or tritium whose sample results did not exceed the screening level, defined 


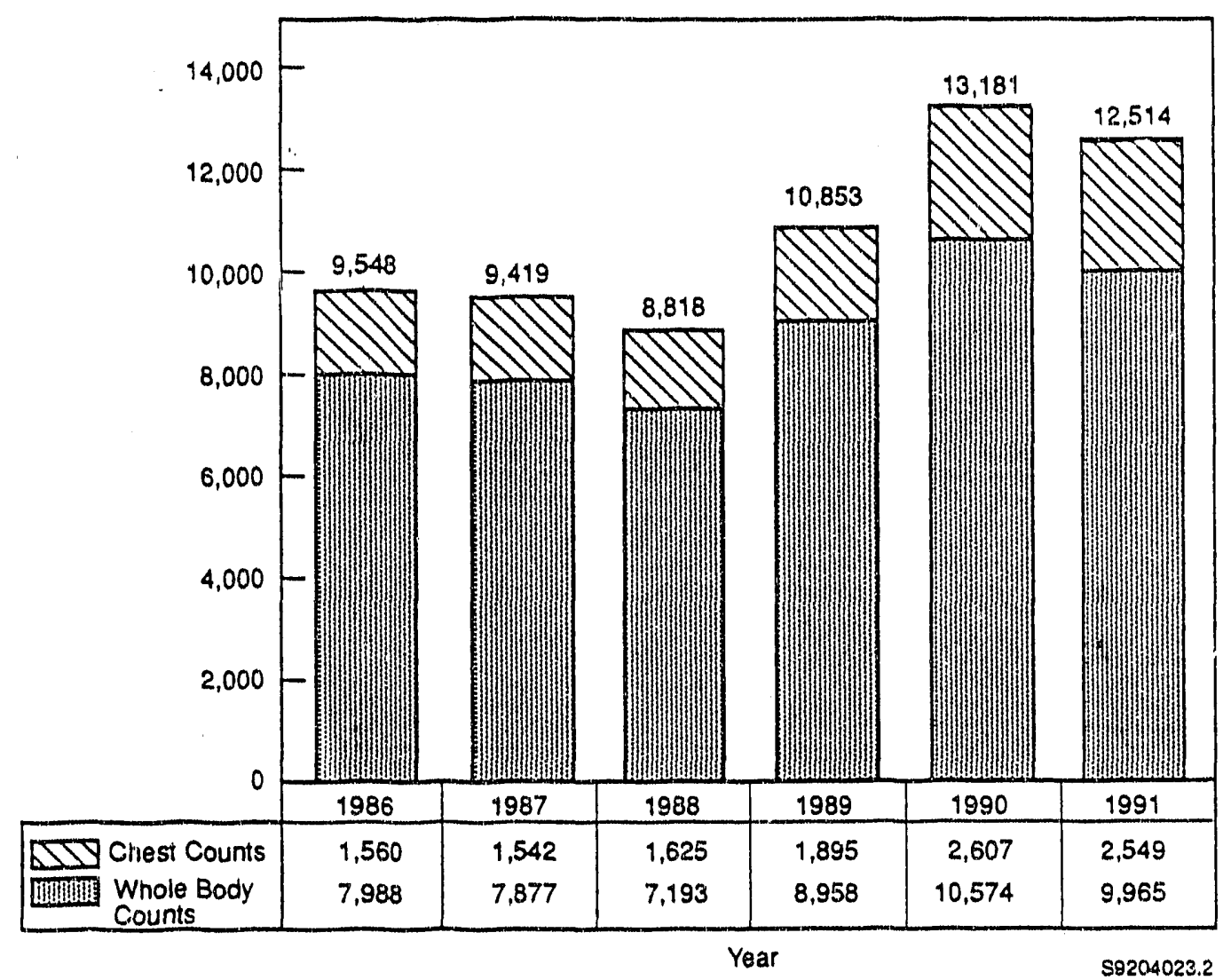

FIGURE 2.3. Routine In Vivo Measurements Made at the In Vivo Radioassay and Research Facility from 1986 through 1991

as that result which could have indicated a potential first-year effective dose equivalent greater than 10 mrem, based on conservative assumptions. None of the chronic intake evaluations resulted in a 50-year effective dose equivalent above $100 \mathrm{mrem}$.

The I'ternal dose status of the Hanford work force at the end of 1991 is summarized in Table 2.12. Past exposures that are contributing current doses to active workers are included in the lower section of the table. Overall, the number of Hanford workers receiving internal doses decreased by $35 \%$ in 1991 compared to 1990. Fifty-one workers received doses in 1991 which exceeded $1 \%$ of the DOE radiation protection standard of $5 \mathrm{rem} /$ year effective dose equivalent, down from 56 workers in 1990 and 64 in 1989. Of the new evaluations listed, all but three cases resulted in a 50-year committed effective dose equivalent of less than 100 mrem (which were assigned to the year of intake in accordance with current Hanford practices for recording low doses). One of the three higher-dose cases resulted from an incident in 1991 involving a WHC worker; the other two cases involved PNL workers who were identified through the routine bioassay program. 
TABLE 2.9. Summary of Potential Exposure Incidents During 1991

\begin{tabular}{|c|c|c|c|c|c|c|}
\hline Area & $\begin{array}{c}\text { Facility } \\
\text { ID }\end{array}$ & $\begin{array}{l}\text { Facility } \\
\text { Custodian }\end{array}$ & $\begin{array}{l}\text { Number of } \\
\text { Incidents }\end{array}$ & $\begin{array}{l}\text { Number of } \\
\text { Workers }\end{array}$ & $\begin{array}{c}\text { Worker } \\
\text { Contractor }\end{array}$ & $\begin{array}{l}\text { Principal } \\
\text { Nuclide }\end{array}$ \\
\hline $100 A$ & $\begin{array}{l}105 \mathrm{KE} \\
105 \mathrm{~N}\end{array}$ & $\begin{array}{l}\text { WHC } \\
\text { WHC }\end{array}$ & 2 & $\begin{array}{l}6 \\
1\end{array}$ & $\begin{array}{l}\text { WHC } \\
\text { WHC }\end{array}$ & $\begin{array}{l}\text { Cs-137 } \\
\text { Co-60 }\end{array}$ \\
\hline $200 E$ & Purex & WHC & $\begin{array}{l}1 \\
1 \\
2\end{array}$ & $\begin{array}{l}1 \\
1 \\
2\end{array}$ & $\begin{array}{l}\text { WHC } \\
\text { WHC } \\
\text { WHC }\end{array}$ & $\begin{array}{l}\text { U-nat } \\
\text { Cs-137 } \\
\text { Pu-239 }\end{array}$ \\
\hline $200 W$ & $\begin{array}{l}234-5 Z \\
241 Z\end{array}$ & $\begin{array}{l}\text { WHC } \\
\text { WHC }\end{array}$ & $\begin{array}{l}4 \\
1\end{array}$ & $\begin{array}{l}9 \\
7\end{array}$ & $\begin{array}{l}\text { WHC } \\
\text { KEH }\end{array}$ & $\begin{array}{l}\text { Pu-239 } \\
\text { Pu-239 }\end{array}$ \\
\hline 300 & $\begin{array}{l}324 \\
325\end{array}$ & $\begin{array}{l}\text { PNL } \\
\text { PNL }\end{array}$ & $\begin{array}{l}1 \\
1 \\
1\end{array}$ & $\begin{array}{l}1 \\
1 \\
1\end{array}$ & $\begin{array}{l}\text { KEH } \\
\text { KEH } \\
\text { PNL }\end{array}$ & $\begin{array}{l}\mathrm{H}-3 \\
\mathrm{Cs}-137 \\
\mathrm{Am}-241\end{array}$ \\
\hline 400 & & & 0 & 0 & & \\
\hline Total & & & 15 & 30 & & \\
\hline
\end{tabular}

(a) Initially scheduled as contractor-requested measurement.

Because of the severance of the analytical services contract (on June 1, 1990), the excreta bioassay portion of the monitoring program suffered significant disruption throughout 1991 . Consequently, excreta measurement statistics in the 1990 annual report (see Tables 2.7 and 2.8 in Lyon et al. 1991) were based on samples coliected, many of which had not been analyzed. Table 2.13 summarizes the 1990 excreta results statistics, now that the data have been finalized, and is a corrected version of Table 2.8 in Lyon et al. (1991). The actual number of valid excreta results totalled 4856 , or $4.5 \%$ less than the estimate given in Lyon et al. (1991). The overall sum of in vivo and excreta bioassay measurements during 1990 was 18,242. A total of 1613 excreta sample requests were designated as no-result samples for 1990; the ratio of no-results to successful results was 0.29 overall. Unsuccessful sample collections were attributed to: no sample received ( $31 \%$ of total so classified), lost container $(17 \%)$, insufficient sample volume $(6 \%)$, lost-in-lab (9\%), and lost due to termination of the analytical support services contract (38\%). 
TABLE 2.10. Comparison of Internal Exposure Incidents and Internal Exposure Dose Assessments, 1987-1991

\begin{tabular}{|c|c|c|c|c|c|c|}
\hline & & 1991 & 1990 & 1989 & $\underline{1988}$ & 1987 \\
\hline$\underset{N}{N u m}$ & $\begin{array}{l}\text { ser Incidents, total } \\
\text { umber of workers }\end{array}$ & $\begin{array}{l}15 \\
30\end{array}$ & $\begin{array}{l}14 \\
30\end{array}$ & $\begin{array}{l}22 \\
33\end{array}$ & $\begin{array}{l}12 \\
25\end{array}$ & $\begin{array}{l}14 \\
20\end{array}$ \\
\hline Evalt & ations, total & 130 & 228 & 291 & 80 & 173 \\
\hline$R_{\theta}-$ & ovaluations & $1^{(a)}$ & 5 & 7 & 8 & 16 \\
\hline $\begin{array}{c}\text { Nor } \\
\text { In } \\
\text { S } \\
H \\
\text { C }\end{array}$ & $\begin{array}{l}\text { cases } \\
\text { idents } \\
\text { ecial requests } \\
\text { gh routines } \\
\text { rronic exposures }\end{array}$ & $\begin{array}{r}129 \\
30 \\
0 \\
69 \\
30\end{array}$ & $\begin{array}{r}223 \\
30 \\
5 \\
93 \\
95\end{array}$ & $\begin{array}{r}284 \\
33 \\
3 \\
51 \\
197\end{array}$ & $\begin{array}{r}72 \\
26 \\
8 \\
38\end{array}$ & $\begin{array}{r}157 \\
75 \\
31 \\
51\end{array}$ \\
\hline & dose $\theta^{(0)}$ & 85 & 104 & 77 & 22 & 147 \\
\hline $\begin{array}{l}\text { (a) } \\
\text { (b) } \\
\text { (c) }\end{array}$ & $\begin{array}{l}\text { Two additional re- } \\
\text { time of this compil } \\
\text { The criteria for dec } \\
\text { considerably trom } \\
\text { For } 1986-1988 \text {, the } \\
\text { standard or maxim } \\
\text { confirmed intake }\end{array}$ & $\begin{array}{l}\text { tions w } \\
\text { which c } \\
\text { o } 1991 \\
\text { for do } \\
\text { rmissil } \\
\text { orded. }\end{array}$ & $\begin{array}{l}\text { signed } \\
\text { tally ex } \\
\text { yearly } \\
\text { essme } \\
\text { dy burd }\end{array}$ & $\begin{array}{l}1 \text { but } w \\
\text { worker } \\
\text { ers are } \\
1 \% \text { of } \\
\text { aginnin }\end{array}$ & $\begin{array}{l}\text { ot comp } \\
\text { ovalue } \\
\text { ompare } \\
\text { diation } \\
989 \text {, do }\end{array}$ & $\begin{array}{l}\text { at the } \\
\text { langed } \\
\text { tion } \\
\text { any }\end{array}$ \\
\hline
\end{tabular}

\subsection{PRESENTATIONS}

Bihl, D. E., and J. A Maclellan. 1991. "Experience with Quality Assurance Standards Applied to In Vitro Bioassay." Presented at the Third Conference on Radiation Protection and Dosimetry, October 21-24, 1991, Orlando, Florida.

MacLellan, J. A., T. P. Lynch, and G. A. Rieksts. 1991. "Application of the Generic ANSI N13.30 Minimum Detectable Activity Equation to Multichannel Analysis." Presented at the 37th Annual Conference on Bloassay, Analytical and Erivironmental Radiochemistry, October 7-11, 1991, Ottawa, Ontario, Canada. 
TABLE 2.11. Summary of Potential Exposure Cases Identified through the Routine Bloassay Program During 1991

\begin{tabular}{|c|c|c|c|c|c|c|}
\hline Area & Facility & $\begin{array}{l}\text { Facility } \\
\text { Custodian }\end{array}$ & $\begin{array}{l}\text { Exposure } \\
\text { Typ } \theta^{(\theta)}\end{array}$ & $\begin{array}{l}\text { Number of } \\
\text { Workers }\end{array}$ & $\begin{array}{l}\text { Worker } \\
\text { Contractor }\end{array}$ & $\begin{array}{l}\text { Principal } \\
\text { Nuclide }\end{array}$ \\
\hline 200-E & PUREX & WHC & A & 1 & WHC & ${ }^{90} \mathrm{Sr}$ \\
\hline $200-W$ & $224-U$ & WHC & C & $\begin{array}{l}13 \\
11\end{array}$ & $\begin{array}{l}\text { KEH } \\
\text { WHC }\end{array}$ & $\begin{array}{l}\text { U-nat } \\
\text { U-nat }\end{array}$ \\
\hline \multirow[t]{2}{*}{$300-A$} & $\begin{array}{l}306-W \\
308 \\
309 \\
325\end{array}$ & $\begin{array}{c}\text { PNL } \\
\text { PNLWHC } \\
\text { PNL } \\
\text { PNL }\end{array}$ & $\begin{array}{l}C \\
A \\
A \\
C\end{array}$ & $\begin{array}{l}2 \\
1 \\
1 \\
4\end{array}$ & $\begin{array}{l}\text { PNL } \\
\text { PNL } \\
\text { PNL } \\
\text { PNL }\end{array}$ & $\begin{array}{l}{ }^{238} \mathrm{U} \\
{ }^{239} \mathrm{Pu} \\
{ }^{239} \mathrm{Pu} \\
{ }^{3} \mathrm{H}\end{array}$ \\
\hline & \multicolumn{2}{|c|}{ Unknown ${ }^{(b)}$} & $A$ & 1 & PNL & ${ }^{239} \mathrm{Pu}$ \\
\hline
\end{tabular}

(a) Acute (A) or chronic (C) intake scenarios.

(b) The most likely facilities for possible intake were 308 Building (300-A), 303C Building (300-A), or 2312 Building (200-W). 
TABLE 2.12. Internal Dose Status of the Mariford Work Force at 1991 Year End

\begin{tabular}{|c|c|c|c|c|c|}
\hline \multirow{2}{*}{ Percent RPS ${ }^{(b)}$} & \multicolumn{5}{|c|}{ Number of Workers ${ }^{(a)}$} \\
\hline & $\overline{D O E}$ & KEH & PNL & WHC & Total \\
\hline & 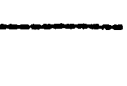 & valuat & - & - & \\
\hline \multicolumn{6}{|l|}{ Acute Intake } \\
\hline$<1$ & 0 & 4 & 0 & 5 & 10 \\
\hline $1-<5$ & 0 & 0 & 2 & 1 & 2 \\
\hline $5-<10$ & 0 & 0 & 1 & 0 & 1 \\
\hline 210 & 0 & 0 & 0 & 0 & 0 \\
\hline \multicolumn{6}{|l|}{ Chronic Intake } \\
\hline$<1$ & 0 & 13 & 6 & 11 & 30 \\
\hline \multirow[t]{2}{*}{21} & 0 & 0 & 0 & 0 & 0 \\
\hline & \multicolumn{5}{|c|}{-Assessed in Prior Evaluations } \\
\hline Acute Intake & & & & & \\
\hline & 0 & 1 & $11(2)$ & $17(1)$ & 29 \\
\hline $1-<5$ & $1(1)$ & 1 & 12 & 20 & 24 \\
\hline $5-<10$ & 0 & 1 & 2 & $8(2)$ & 11 \\
\hline $10-<50$ & 0 & 0 & 4 & 7 & 11 \\
\hline $50-<100$ & $1(1)$ & 0 & 0 & 1 & 2 \\
\hline$>100$ & 0 & 0 & 0 & 0 & 0 \\
\hline Total & 2 & 20 & 38 & 70 & 120 \\
\hline
\end{tabular}

(a) Numbers in parentheses refer to assessed doses due to offsite exposures.

(b) Percent of the Radiation Protection Standard of 5 rem/year annual effective dose equivalent assigned to 1991. If the intake occurred in 1991 and the 50-year committed effective dose equivalent was less than $100 \mathrm{mrem}$, then the total committed effective dose equivalent was assigned to 1991. 
TABLE 2.13. Corrected Excreta Measurements for Samples Requested During CY $1990^{(\mathrm{e})}$

Type/Reason

${ }^{3} \mathrm{H}$-urine

Routine schedule Special request Intake follow-up

${ }^{80}$ Sr-urine

Routine schedule Special request Intake follow-up

Uranium-urine

Routine schedule Special request Intake follow-up

Plutonium-urine

Routine schedule Special request Intake follow-up Rosearch request

Other TAU-urine Routine schedule Spocial request Intake follow-up

Plutonium-fecal

Routine schedule Special request Intake follow-up

${ }^{90}$ Sr-fecal

Routine schedule Special schodule Intake follow-up

Other misc.

Routine schedule
DOE

KEH

PNL

WHC

129

0

0

0

9
2
0

13

0

0

248

0
0

8

1

0

40

7

1393

41
7

0

0

0

64

0

0

83

12

2

529

24

11

676

36

13

13

356

0

2

0

0

0

215

5

6

0

1599

40

25

2

2183

45

33

2

0

0

0

0

2

9

0

3

9

0

3

18

0

8

$0 \quad 0$

0

0

0

0

0

35

35

40

0

40

1

0

0

0

0

0

0

3

0

0

1

0

1 
Table 2.13. (cont'd)

\begin{tabular}{|c|c|c|c|c|c|}
\hline Ixpe/Reason & DOE & KEH & PN1 & WHC & TOTAL \\
\hline Analyses Totals & 26 & 683 & 481 & 3666 & 4856 \\
\hline $\begin{array}{l}\text { Recounta (not include } \\
\text { above total) } \\
\text { Plutonlum - urine } \\
\text { Other TRU - urine }\end{array}$ & $\begin{array}{l}0 \\
0\end{array}$ & $\begin{array}{l}0 \\
0\end{array}$ & $\begin{array}{r}11 \\
4\end{array}$ & $\begin{array}{r}21 \\
0\end{array}$ & $\begin{array}{r}32 \\
4\end{array}$ \\
\hline
\end{tabular}

(a) This table represents final valid result counts per category and is an update to proliminary data reported in the 1990 annual report.

\subsection{PUBLICATIONS}

Bihl, D. E., and J. A. MacLellan. 1991. "Experience with Quality Assurance Standards Applied to In Vitro Bloas: ay." in Proceedings of the Third Conference on Fiadiation Protection and Dosimetry, ORNLTM-11882, Oak Ridge National Laboratory, Oak Fildge, Tennesseo.

Sula, M. J., E. H. Carbaugh, and D. E. Bihl. 1991. Technical Basis for Internal Dosimetry at Hanford. PNL-6866, Rev.1, Pacific Northwest Laboratory, Richland, Wasinington.

\subsection{PROGRAM-RELATED PROFESSIONAL ACTIVITIES}

Bihl, D. E.--Member DOE Comprehensive Epidemiologic Data Rescurce, Dosimetry Working Group.

Carbaugh, E. H.-Member of American National Standards institute (ANSI) standard review committee N13,14, Standard for Minimum Requirements in Tritium Bloassay and Dosimetry.

Carbaugh, E. H.--Chairman American Society for Testing and Materials (ASTM) Committeo E.50.xx working group for developing a standard for dosimetry of transuranic-contaminated wounds.

MacLollan, J. A.-Member of American National Standards Institute (ANSI) standard committeo N13.30, Periormance Criteria Against Which Radiobloassay Laboratories Will Be Tested. 
The In Vivo Measurement Progre: n has been an integral part of personnel ciosimetry at Hanford since 1959, assisting in detecting the deposition of radioactive materials in Hanford employees. Program requirements are outlined in the Hanford Site Services Handbook (RL 1983). The In Vivo Measurement Program provides for the management, operation, and maintenance of the in vivo counting facilities and equipment located in the 747-A Building, the 747-A Trailer, a mobile in vivo counting facility, and the Emergency Decontamination Facility (EDF). The routinely used measurement facilities are located at the 747-A Building and include the Preview Counter (used for stand-up screening in whole body measurements), the iron room and stainless steel room (each containing lung counting systems), and the Palmer Room, formerly known as the Utah Room (containing the coaxial germanium detector system). Operating hours are from 7:00 a.m. to 4:30 p.m. on weekdays. The facilities and equipment are also available during off-hours on an on-call basis. Data and results of measurements are transmitted to the HRRP database for permanent record. Daily operational and functional checks are performed on all routinely used counting systems, which are also periodically calibrated to ensure their accuracy. The staff participate in intercomparison programs to further improve the accuracy of operations. The activities of this program, including special studies and development work carried on during 1991, are described in the following subsections.

\subsection{ROUTINE PROGRAM}

Several types of routine in vivo measurements are made on personnel. The type of measurement made on each person is determined by the type of radioactive material to which that person is potentially exposed. Generally, if an employee does not work with TRU radionuclides, only a whole body count is performed to detect the higher energy garnma rays emitted by fission or activated corrosion products. If the work involves TRU radionuclides, lung and whole body counts are done. If radioactivity is detected by either of these measurements, several other types of counts may be done to identify and quantify the activity in the body.

The number and types of measurements made on personnel during 1991 are listed in Table 3.1. A total of 13,909 measurements were made for RL and the Hanford contractors in 1991, representing a 7\% increase over the number performed in 1990. Table 3.2 shows the in vivo measurements made at the In Vivo Radioassay Research Facility (IVRRF, formerly known as the Whole Body Counting Facility) from 1987 to 1991. The 1991 total of 11,195 whole body counts is $8 \%$ higher than the same tally for 1990 . Lung counts for 1991 totaled 2647, which is a $1 \%$ decrease from 1990 . 
TABLE 3.1. Measurements Made on Hanford Personnel During $1991^{(a)}$

$\begin{array}{lcrrrrr}\text { Contractor } & \begin{array}{c}\text { Whole Body } \\ \text { Counts }\end{array} & & \begin{array}{c}\text { Chest } \\ \text { Counts }\end{array} & \begin{array}{c}\text { Other } \\ \text { Counts }\end{array} & \text { Total } \\ \text { BSC } & 125 & & 12 & & 0 & 137 \\ \text { DOE } & 387 & & 4 & 3 & 394 \\ \text { WHC } & 7,781 & 1,576 & 48 & 9,405 \\ \text { HEHF } & 41 & & 0 & 0 & 41 \\ \text { KEH } & 1,302 & 726 & 0 & 2,028 \\ \text { PNL } & 1,559 & 329 & 16 & 1,904 \\ \text { Total } & 11,195 & 2,647 & 67 & 13,909\end{array}$

(a) Includes routine and special counts.

TABLE 3.2. In Vivo Measurements Made at the in Vivo Radioassay and Research Facility from 1987 through 1991(a)

\begin{tabular}{|c|c|c|c|c|c|}
\hline MeasurementlYear & 1987 & 1988 & 1989 & 1990 & 1991 \\
\hline $\begin{array}{l}\text { Whole Body } \\
\text { Counts }\end{array}$ & 8,070 & 7,187 & 9,081 & 10,320 & 11,195 \\
\hline Lung Counts & 1,705 & 1,652 & 1,954 & 2,679 & 2,647 \\
\hline Others & 98 & 60 & 37 & 35 & 67 \\
\hline Total & 9,873 & 8,899 & 11,072 & 13,034 & 13,909 \\
\hline
\end{tabular}

(a) Values for CY 1990 shown here will differ from the fiscal year 1990 values as reported in the 1990 report (Lyon et al. 1991). 
Most of the routinely scheduled whole body exams with positive results this year were ultimately associated with either medically administered radioactivity $\left({ }^{201} \mathrm{Th},{ }^{202} \mathrm{Th},{ }^{20 \mathrm{~m}} \mathrm{Te},{ }^{131} \mathrm{l}\right.$, or ${ }^{67} \mathrm{Ga}$ ), or environrnentally derived ${ }^{137} \mathrm{Cs}$. Investigations of the ${ }^{137} \mathrm{Cs}$ results indicated that most workers having such results had not been associated with any off-normal working conditions and were regular consumers of wild game (notably deer, elk, and bear), or had traveled to Eastern Europe.

An anatomical marker system was incorporated into the $4 \times 4 \times 16 \mathrm{Nal}$ system to identify anatomical landmarks to assist in determining the distribution of radioactive material in the body. The magnetic markers can be positioned anywhere along the scanning bed to correspond with specific anatomical landmarks (e.g., shoulder or elbow). A microswitch located on the underside of the carriage is activated by the markers and provides exactly 1000 counts to the specific channel representing that position. A plot is obtained showing the landmarks; by subtracting the 1000 counts, the number of counts from the subject can be determined.

All the routine counting systems were interfaced to the multichannel analyzers resident on a Digital Equipment Corporation (DEC) Model 3100 workstation. The workstation was interfaced to the Hewlett Packard (HP) 9000 . Codes were written for the workstation to backup the routine calculation codes on the HP 9000 . Verification and validation were completed for most of the codes. No downtime related to fallures of the multichannel analyzer (MCA) was experienced during the year. A second DEC Model 3100 workstation was purchased as a backup and programming started on the routine calculations.

Preparation for having the program accredited through DOELAP began in 1991. A draft quality assurance (QA) plan was written as the basis for evaluating the program. Two bottle manikin absorption phantoms were received from the DOE Radiological and Environmental Sciences Laboratory (RESL) in Idaho Falls, Idaho. Measurements were made of the phantoms on the coaxial germanium system and the standup counter to evaluate the precision, bias, and minimum detectable amounts for these systems. Data analysis is planned after receipt of the information on activity loadings of the phantoms from RESL.

A computer program developed at LLNL, to calculate the chest-wall thickness based on diagnostic ultrasound measurements was put into routine use. The problems with the hardware (defective mother-board) and incompatible software reported last year were resolved. The system allows the image to be electronically stored and the chest-wall thickness results to be automatically calculated.

A draft of the Whole Body Counting Program SOW was completed this year. The SOW documents the operating policies for the program, including a new statistical approach based 
on the concepts presented in the draft ANS! Standard N13.30. ${ }^{\text {(a) }}$ Much time and effort was spent on developing the decision levels to be used as the bases for reporting statistically significant measurable quantities of radioactive material in the body. The ANSI N13.30 statistical approach was modified to address in vivo measurements that are routinely made to detect multiple nuclides. Thousands of in vivo measurement results were statistically evaluated to improve the prediction of the peak region-of-interest baseline and to empirically derive the non-polsson variance component to precisely define the decision-level equations for application at Hanford. Implementation of the policies and statistical approach in the SOW is planned for January 1992.

A 0.3 full-time equivalent technician joined the Whole Body Counting Program staff this year to better accommodate the increased volume of in vivo measurements. The new technician splits time between the Whole Body Counting Program, the Bloassay Audit Program, and the Phantom Library Program.

Several surveillances of the Whole Body Counting Program were conducted by WHC and RL this year. Corrective actions related to the findings and observations were initiated in a timely manner and, in most cases, have been completed.

The fire protection assessment for the IVRRF was updated to estimate costs and recovery times resulting from a fire at the IVRRF. There remains no fire detection and alarm capability in the 747-A Trailer.

A $400-\mathrm{Mb}$ disk and a $100-\mathrm{Mb}$ disk for the HP 9000 were obtained to effectively double the system's disk capacity. The disks were used periodically during the year to back up files.

The underground piping below the IVRRF was found to be severely corroded and was replaced with above-grade piping. The sanitary water line feeding the 747-A Building from the Richland city supply was also replaced. Fortunately, the only disruption of the routine in vivo counting services resulted from the increased noise and dust levels and the increased number of persons in the 747-A Building during business hours.

Fencing was erected around the liquid nitrogen storage tanks on the north side of the 747-A Building to provide added property protection and reduce the potential for equipment damage and personal injury due to vandalism. The enclosure around the liquid nitrogen tanks is shown in Figure 3.1.

(a) American National Standards Institute (ANSI). 1989. Performance Criteria Against Which Bioassay Analysis Laboratories Will Bo Tested. Draft ANSI N13.30, New York, New York. 


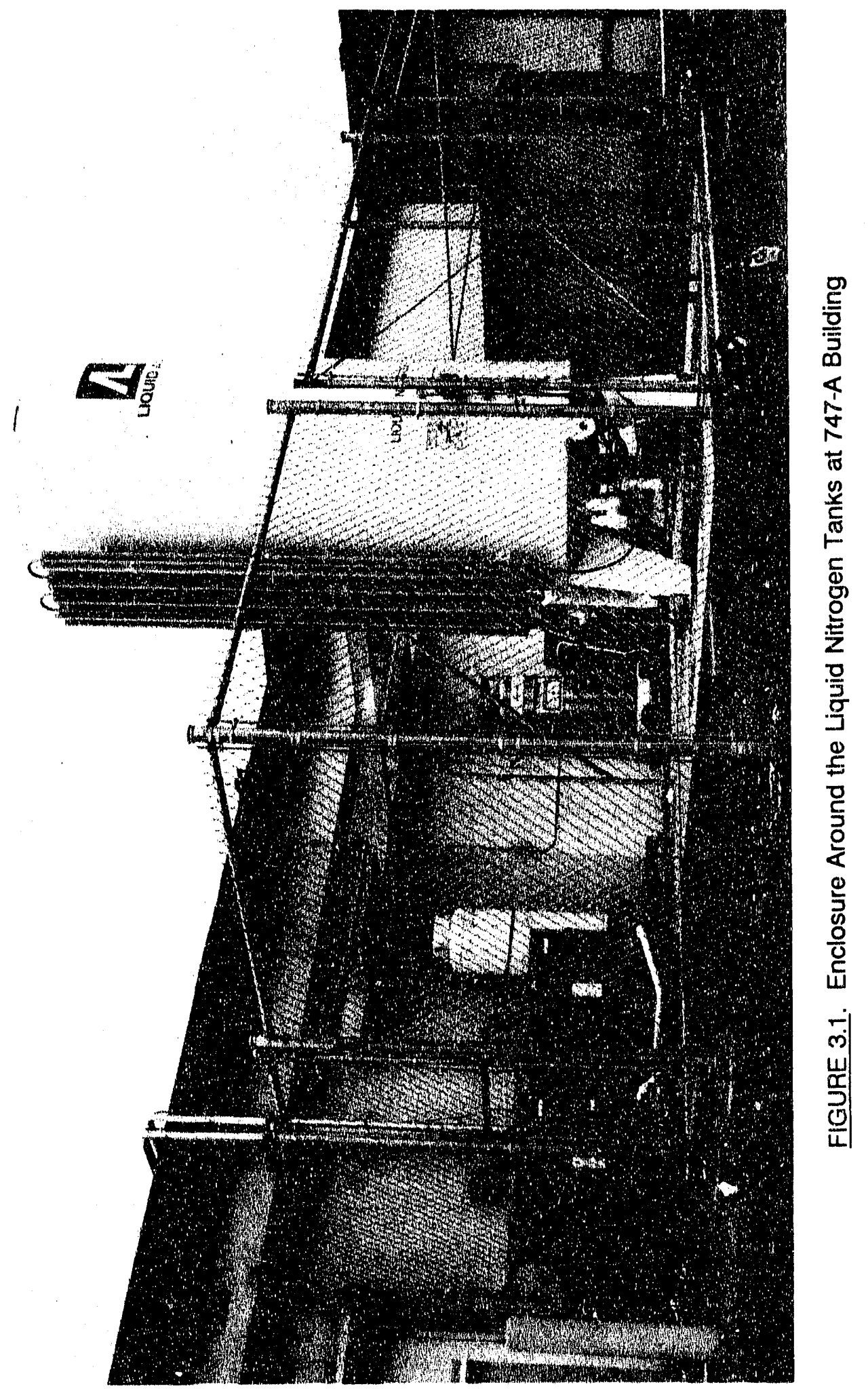

3.5 


\subsection{ADDITIONS OR CHANGES TO EQUIPMENT AND FACILITIES IN 1991}

Additions and changes to equipment included a new computer workstation, a new ultrasound system, an oxygen monitoring system for the counting cells, and a remotely operated in vivo counting system.

\subsubsection{Workstations}

A second DEC WS-3100 analyzer system was received. When the routine calculations are programmed, the system will provide backup to the primary workstation currently interfaced with the counting systems.

\subsubsection{Improved Measurements of Chest-Wall Thickness}

The new ultrasound system, including the analysis software from LLNL, was put into routine use after the technicians were trained. The need for additional training was identified as a means to improve the precision and accuracy of the measurement process.

Subsequently, training classes for the IVRRF staff were conducted by a certified sonographer on the operation of the ultrasound unit, identification of anatomical features on the ultrasound image, and interpretation of the image data. Measurements were made of a single subject as the basis for evaluating the actual variability of the results. Analysis of the measurement data will continue into 1992.

\subsubsection{Counting Cell Safety}

An evaluation of the effects of nitrogen releases into the counting cells showed that oxygen concentrations in the cells with automatic liquid nitrogen fill systems could fall below $19.5 \%$ in the event of a worst-case release to the cell. Although it was determined that the probability of such an occurrence is extremely low, the possible consequences could be lifethreatening. Most other DOE in vivo counting facilities were found to have oxygen monitoring systems in their counting cells. Consequently, oxygen monitoring was installed in the two counting cells with automatic fill systems that are routinely used for in vivo measurements. The monitoring systern was installed at a significant savings, compared to purchasing a commercial system with capital funds, and includes portable instruments wired to a permanent power supply.

\subsubsection{Operation of the Remotely Operated In Vivo Counting System}

The trailer housing the remotely operated in vivo counter was moved to the 200-East Area and put into routine operation as screening counter similar to the standup counter in the 747-A Building. The technician in 747-A controls operation of the counting system from an 
IBM Model 25 with a multichannel analyzer board. A second IBM Model 25 in the trailer is connected to the computer in 747-A and can be used to control the counter.

There is continuous audible and visual communications with the subjects in the trailer. Visual images are transmitted to 747-A via a Photophone system. Problems with line noise that caused disruption of the image transmission with the Photophone system were solved with the installation of new modems that were not as sensitive to line noise transients. The operator can toggle between the two video cameras in the traller (a second camera was installed in 1991) using the high-voltage switch to obtain a view of the counter or a panoramic view of the trailer. A dedicated phone line between the trailer and 747-A provides audible communications.

The calculational algorithms were written, tested, and verified. An algorithm was developed to compensate for radon progeny activity to reduce the number of positive results due to this naturally occurring source of radioactive material.

Westinghouse Hanford Company personnel were trained to assist in the set-up for the performance tests each time the system is used. This eliminated the need for travel to and from the counter located in the 200-East Area by IVRRF staff for routine operations.

A picture of the new counting system is shown in Figure 3.2. The detectors are shielded with lead bricks encased in 3/16-in.-thick steel. The lead behind and on the sides of the detectors and on the floor is 4 in. thick, and on the front and sides of the subject and on the ceiling is $2 \mathrm{in}$. thick. There are six Nal(TI) scintillation detectors. Five of them are $4 \mathrm{in}$. square and $16 \mathrm{in.}$ long; one is $4 \mathrm{in.} \mathrm{square}$ and $8 \mathrm{in}$. long. The array of detectors is $66 \mathrm{in}$. long; the top of the array is $72 \mathrm{in}$. above the floor. A $3 / 8$-in.-thick piece of acrylic plastic separates the detectors and the subject being counted. The total area of 4-in.-thick detectors is 352 in. $^{2}$, compared to 370 in. $^{2}$ for the Preview counter in the 747-A Building. Preliminary measurements on adult male subjects in the new counter showed a $15 \%$ lower efficiency for measuring ${ }^{40} \mathrm{~K}$ in the body. This lower efficiency is due partly to the lower cross-sectional area of the detectors and partly to the collimating effect of the shielding, which does not exist in the Preview counter. The background in the ${ }^{40} \mathrm{~K}$ peak was $33 \%$ lower. This lower background is probably because that there are only six glass photomultiplier tubes on the detectors of the new counter, whereas the Preview counter has 27.

\subsection{SPECIAL STUDIES}

\subsubsection{Chest Counting Studies}

Measurements were made of the ${ }^{241} \mathrm{Am}$ phantom that includes half of the skeleton from a whole-body donor to the U.S. Transuranium Registry. The measurements will be used to 


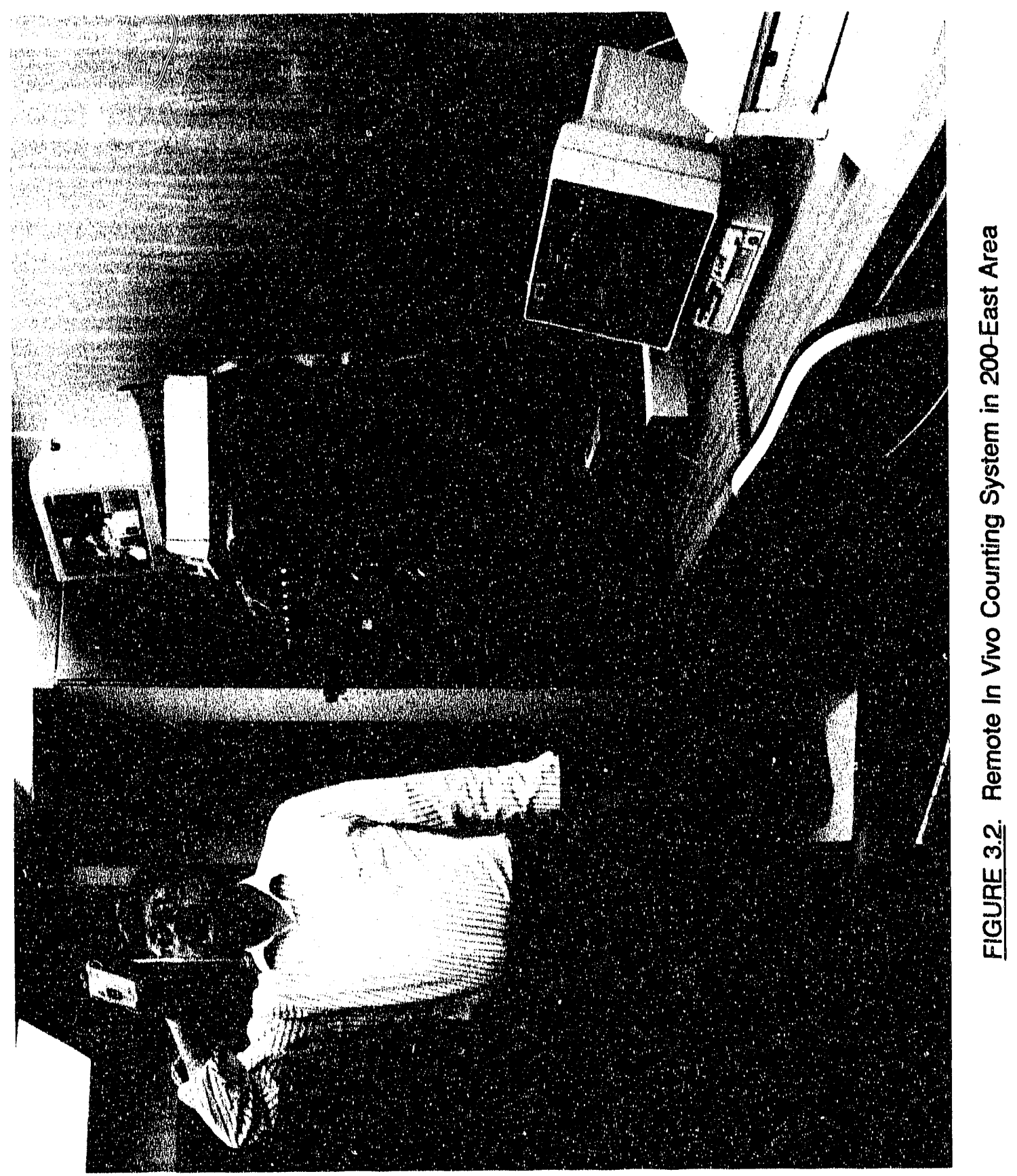


verify skeletal activity contributions to anterior chest and liver measurements. Preliminary anterior measurements of the LLNL phantom loaded with liver activity $\left({ }^{241} \mathrm{Am}\right)$ were made to estimate the count rate contribution from the liver to the count rate over the chest.

Preliminary measurements were also made to compare the count rates obtained from anterior and posterior measurements with a phantom and a human subject. The ratio of anterior to posterior measurements of the LLNL phantom loaded with lung activity was 1.21, compared with the anterior to posterior ratio of 0.91 for a known lung cieposition case. The difference is at least partially due to the lack of scapulae in the phantom. The data for the human subject seem to indicate that a higher count rate can be obtained using the posterior counting configuration compared to the anterior position. However, the effects of differences between the activity distribution in the phantom and the subject, as well as the effect of the counting geometry on the count rate, have not been accounted for.

\subsubsection{Evaluation of Radionuclide Library and Peak Search Routines}

The results of the peak search routine for the germanium detection systems were reviewed to identity those peaks present in the background spectra as well as in the human spectra. The peaks present in both spectra were identified. A procedure was written to improve the measurement quality control through ongoing evaluation of the spectrum while it is accumulating, to review ${ }^{40} \mathrm{~K}$ values for total body results, and to identify peaks that may indicate the presence of unexpected radioactive material in the body.

\subsubsection{Maintenance of the Planar Germanium Detectors}

The reliability of the planar germanium detectors has been greatly improved as a result of the aggressive maintenance program conducted during the last two years. Six detectors were operational in both ceils used for routine chest counts during $95 \%$ of the year. The improvement in the detectors' performance can be attributed to several measures:

- greatly improved vacuum vessel integrity resulting from the use of a replacement helium leak detection system and valve operators to achieve better vacuum

- the use of a new bonding agent and evacuation of the bonding agent before application to remove air bubbles

- components that have proven to be more reliable than the original detector components

- thermal cycling at room and higher temperatures to regenerate the charcoal trap in the vacuum vessel 
- the use of a shotky power diode as a liquid nitrogen sensor to provide more reliable automatic filling of the detectors.

\subsubsection{Phantom Library}

In 1991, the administrative procedures for loaning phantoms to DOE facilities were developed. A database was set up to contain descriptions and data for each of the phantoms in the current inventory; a second database package was procured and will be installed and put into routine use in 19\$2. A scheduling and tracking system for the loan of the phantoms was also developed. The design of a catalog of the available phantoms was started and will be completed in 1992. Problems were encountered with the formulation of the polyurethane filler for making solid bottle manikin absorption phantoms.

\subsection{PRESENTATIONS}

Lynch, T. P. 1991. "Hanford In Vivo Counting Program." Presented at the 1991 Department of Energy Intercalibration Committee Lung Counting Workshop, February 11-14, Las Vegas, Nevada.

Lynch, T. P. 1991. "Improving In Vivo Calibration Phantoms." Presented at the 37th Annual Conference on Bioassay, Analytical and Environmental Radiochemistry, October 7-11, 1991, Ottawa, Canada.

\subsection{PUBLICATIONS}

Lynch, T. P., and H. E. Palmer. 1991. "In Vivo Measurements of Am-241 in the Lung." Chapter written for International Atomic Energy Agency book on in vivo measurements.

Mays, C. W., R. L. Aamodt, K. G. W. Inn, D. R. Brown, R. R. Greenberg, V. G. Iyengar, F. J. Schima, L. S. Slaback, J. W. Tracy, K. L. Mossman, and T. P. Lynch. 1991. "External Gamma Ray Counting of Selected Tissues from a Thorotrast Patient." Accepted for publication in Health Physics.

Palmer, H. E., G. A. Rieksts, and T. P. Lynch. 1991. "Performance of an Array of LargeVolume Germanium Detectors for Whole-Body Counting." Health Physics 61 (5):595-600. 


\subsection{PROGRAM-RELATED PROFESSIONAL ACTIVITIES}

Lynch, T. P. - Member of ASTM Task Group E-10.04-27 for developing a standard on the estimation of low-energy photon-emitters in a wound. In 1991, an initial draft chapter, "Calibration and Standardization," was prepared.

Lynch, T. P. - Chairman of the ANSI N13.30 working group to develop a standard for the bottle manikin absorption phantom. An outline for the standard was developed and the initial meeting of the working group was held in Ottawa during the Bloassay Conference. 


\subsection{HANFORD EXTERNAL. DOSIMETRY PROGRAM}

The Hanford External Dosimetry Program is a multifaceted effort involving all Hanford contractors. Dose-of-record information from external radiation for Hanford personnel is provided by this program in compliance with the requirements of the DOE, as set forth in DOE Order 5480.11 (1988a) and DOE Order 5480.15 (1987a). Program dosimeter results are used by contractor personnel to project, control, and measure radiation doses received by personnel. Program staff also provide sitewide nuclear accident dosimetry to comply with DOE Order 5480.11 requirements and environmental dosimetry to support PNL and WHC Environmental Surveillance Programs.

\subsection{EXTERNAL PERFORMANCE TESTING EVALUATIONS}

External evaluation of External Dosimetry Program reported doses was conducted in two ways during 1991 , by WHC submitting monthly blind audit dosimeters and by DOELAP formal dosimeter performance testing.

\subsubsection{WHC Audit Dosimeters}

Westinghouse Hanford Company routinely si bmits several audit dosimeters to be processed along with their personnel dosimeters. The PNL External Dosimetry Program successfully passed each monthly blind audit dosimeter ovaluation conducted by WHC during 1991. The program also passed each of the quarterly evaluations conducted by WHC using the DOELAP methodology and criteria. During the entire year, there were only two reported audit doses outside of established tolerance limits for the DOELAP accredited testing categories. The results of these audits are provided by WHC to the Hanford Radiation Protection Historical Files.

\subsubsection{DOELAP Performance Testing}

The Pacific Northwest Laboratory received accreditation under in the DOELAP program during 1989, consistent with the requirements of DOE Order 5480.15. During 1991, retesting of Hanford basic, beta/photon, and multipurpose dosimeters was begun to obtain reaccreditation. After an application for testing was submitted to RL during October 1990, PNL was scheduled by the DOELAP Performance Testing Administrator to begin testing during March 1991, and was informed during October 1991 that it was successful. The results showed significant improvement in PNL's performance in the 1991 DOELAP performance testing, compared to the testing done in 1989. Table 4.1 shows a comparison PNL performance between 1989 and 1991 in all tested categories. An onsite technical program appraisal will be conducted during 1992. 
TABLE 4.1. PNL. Performance in DOELAP Performance Testing in CY 1989 and 1991

\section{Performance Index}

$0-5 \%$

$5-10$

$10-10$

$15-20$

$>\mathbf{2 0}$

\begin{tabular}{cc} 
Number of Categories \\
\hline 1989 & 1991 \\
1 & 6 \\
6 & 8 \\
4 & 9 \\
4 & 4 \\
11 & 0
\end{tabular}

A performance index of less than $30 \%$ is necessary to pass the single exposure tests and $40 \%$ for the mixed exposure categories. Achieving no performarice index greater than $20 \%$ for any tested category is evidence that processing staff are maintaining a high level of quality control in the processing procedures, the dosimeters, and the reader systems.

\subsubsection{Comparison of 1989 and 1991 DOELAP Tested Algorithms}

Before the implementation of the 1991-tested algorithm, a comparison was made between calculated doses with the new and existing algorithm (i.e., algorithm tested in 1989). These results were presented to the Hanford Personnel Dosimetry Advisory Committee to obtain their concurrence in the use of the new algorithm. (a) The comparison showed little difference in individual dose. There was an expected small variation in the cumulative dose because of the difference in dose-reporting protocol between Hanford and DOELAP. The DOELAP doses are reported to the nearest mrem. Hanford has used a procedure for many years to round doses to the nearest multiple of $10 \mathrm{mrem}$. Based on the approval of the committee, the new algorithm was implemented with the January 1992 dosimeter processing. At the request of the committee, a letter was written to the DOELAP Performance Testing Administrator informing them of this change.

(a) Fix, J. J. 1992. "Minutes of Hanford Personnel Dosimetry Advisory Committee Meeting on January 23, 1992." Letter to Distribution, dated January 27, 1992. Copy in the Hanford Radiation Protection Historical Files, Pacific Northwest Laboratory, Richland, Washington. 


\subsection{ROUTINE PROGRAM}

\subsubsection{Routine Processing}

During 1991, PNL processed approximately 168,712 personilel dosimeters. This total Includes the processing of 87,044 personnel dosimeters (i.e., dositneters actually worn by personnel) for which an official dose was reported to the HRRP. (Official doses included "zero" results.) Summaries of the minimum, maximum, and averag is monthly processing volume for each personnel dosimeter type are shown in Table 4.2. The maximum processing volume (24,895 dosimeters) occurred during January 1991 and included annually exchanged basic and multipurpose dosimeters.

Total processing of 168,712 dosimeters vastly exceeds the 87,044 officiai dose results reported because of quality control practices used to ensure the actsuracy of the reported personnel dose. Such quality control practices included

- processing a minimum of two quality control dosimeters within every 50 personnel dosimeters, and with every 25 dosimeters uhen determining chip sensitivity factors

- reprocessing before issuing any personnel dosimeter that has been stored more than 75 days to minimize environmental dose buildup

- reprocessing any dosimeter with an observed reader count grisater than 650 counts in any dosimeter position

- conducting acceptance testing of new dosimeter inserts and holders

- updating chip sensitivity factors for dosimeters (i.e., requiring two processings: before and after irradiation).

TABLE 4.2. Personnel Dosimeters Processed During 1991

\begin{tabular}{lccccc} 
& \multicolumn{3}{c}{ Monthly Processing } & \\
\cline { 2 - 4 } Dosimeter & Minimum & Maximum & Average & Annual Total \\
\cline { 2 - 4 } Basic & 797 & 10,151 & 2,424 & 29,089 \\
Beta/photon & 1 & 144 & 68 & 820 \\
Multipurpose & 2,179 & 9,731 & 3,542 & 42,498 \\
Extremity & 863 & 1,526 & 1,200 & 14,617 \\
Total & & & & 87,044
\end{tabular}


Each year numerous internal audit dosimeters are processed to ensure the integrity of dosimeter processing. During 1991, a total of 3257 internal audit dosimeters were processed. A breakdown of the internal audit dosimeters is shown in Table 4.3. Control charts are used to evaluate the results for each of the audit dosimeter categories. Charts are prepared for every dosimeter and radiation type for each of the 17 dosimeter processings (monthly, quarterly, and annually) conducted each year. A quality control report is prepared for each processing. Coples are distributed to all Hanford contractor radiation protection organizations as well as the Hanford Radiation Protection Historical Files. Coples of the control charts are also provided to the Historical Files.

\subsubsection{Reporting Selected Neutron Dose Results with a Note Code 53}

Only one change in routine practice occurred during 1991. This change was presented to the Hantord Personnel Dosimetry Advisory Committie and involved the automated reporting of dosimeter results for neutron spectra determined to be too thermalized, based on the response of the dosimeter. ${ }^{(a)}$ External Dosimetry staff modified quality control codes to

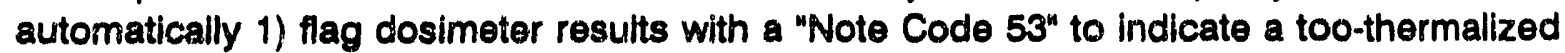
neutron spectrum incident and 2) calculate the neutron dose using the historical algorithm. External Dosimetry staff further review these results and prepare letters concerning the evaluation for each individual's exposure history file. During 1991, a total of 410 results were flagged with a Note Code 53 for this reason. The determination of Note Code 53 results is based on a comparison of the observed dosimeter response profile obtained from exposure to a bare ${ }^{252} \mathrm{Cr}$ source and the sigma pile.

TABLE 4.3. Audit Dosimeters Processed During 1 S91

\begin{tabular}{lcccc} 
& \multicolumn{4}{c}{ Dose Category (a) } \\
\cline { 2 - 6 } Dosimeter & Shallow & $\underline{\text { Deep }}$ & Fast Neutron & $\frac{\text { Blank }}{180}$ \\
Basic & NA & 400 & NA & 180 \\
Beta/photon & 130 & 65 & NA & NA \\
Multipurpose & 419 & 498 & 549 & 686 \\
Rings & NA & 330 & NA & Controls \\
\hline
\end{tabular}

(a) $N A=$ not applicable.

(a) Fix, J. J. 1991. "Minutes of Hanford Personnel Dosimetry Advisory Committee Meeting on January 9, 1991," Letter to Distribution, dated January 18, 1991. Copy in the Hanford Radiation Protection Historical Files, Pacific Northwest Laboratory, Richland, Washington. 
Specifically, if the ratio of (Chip 3 - Chip 5)/(Chip 4-Chip 5) exce日ds a value of 1.38, the result is fiagged as a Note Code 53. The criterion of 1.38 is based on the calculated 3-sigma variation of the ratio observed from exposure of the dosimeters to bare ${ }^{252} \mathrm{Cf}$ source. A letter was prepared for each record reported with a Note Code 53 flag. A copy of this letter is placed in the individual's exposure history file.

Consistent with past practices, External Dosimetry staff routinely identify abnormal dosimeter results with a Note Code 53 whenever the dosimeter data cannot be used directly to calculate dose. For example, dosimeters may be returned with missing chips because of torn Tefion or unacceptable environmental contamination (l.e., dirt, oil, etc.) during processing. In each of these cases, a special evaluation is conducted and documented. During 1991, a total of 111 results were flagged with a Note Code 53 for this reason. If External Dosimetry staff can confidently estimate the dose received, a dose is calculated and reported with the Note Code 53 flag. A letter describing the evaluation is provided to the individual's exposure history file. In the event that External Dosimetry staff cannot estimate a dose, the result is given a Note Code 50 and a letter is sent to the contractor's radiation protection staff for their use in conducting an evaluation of the dose to be recorded. In this case, a copy of the contractor's investigation is placed in the affected individual's exposure history file.

\subsection{SUPPORTING EVALUATIONS}

veral studies were conducted during 1991 on selected aspects of the dosimetry program.

\subsubsection{Anaiysis of Lower Level of Detection}

An analysis of the lower level of detection for the Hanford dosimetry system was conducted using estimates for the deep dose $\left(L_{D}\right)$. Calculated values were based on the method presented by L. D. Curry (1968), and the method recently published by Roberson and Carlson (1992). The results of this analysis were as follows:

$$
\begin{array}{ll}
\text { Roberson and Carlson method } & \\
\text { DOELAP Test Dosimeter Results } & L_{D}=3.10 \mathrm{mrem} \\
\text { Dosed and blank control card results } & L_{D}=3.10 \mathrm{mrem} \\
\begin{array}{ll}
\text { Curry method } & \\
\text { Dosed and blank control card results } & L_{D}=4.25 \mathrm{mrem}
\end{array}
\end{array}
$$

The analysis used data for the multipurpose dosimeter exposed to ${ }^{137} \mathrm{Cs}$ gamma radiation. Based on this information, efforts are underway to develop reporting protocol for shallow, deep, and neutron doses to the nearest mrem above a defined detection or threshold value. 


\subsubsection{Fleld Measurements}

A significant contribution to the studies of neutron dose assessment in Hanford work environments was completed during 1991 with the publication of Pesponse of TLD-Albedo and Nuclear Track Dosimoters Exposed to Plutonium Sources, PNL-7881 (Brackenbush et al. 1991). This report complements earlier studies conducted at Hanford since the inception of operations in the mid-1940s (see Wilson et al. 1990). These studies showed, for the source irradiations, that the CR-39 track-etch dosimeters provided more accurate doses over the entire spectrum of source configurations. The doses calculated with the track-etch dosimeter compared closely with the tissue equivalent proportional counter (TEPC) measurements. The doses were lower than those obtained with the Hanford albedo dosimeter using either the simplified or historical algorithms. For the highly thermalized fields (i.e., obtained using source configurations with Plexiglass shielding), the dose could be overestimated using the simplified algorithm by an order of magnitude.

\subsubsection{Hanford Combination Albedo and Track-Etch Dosimeters}

During December 1990, seven employees were selected to receive a combination Hanford albedo and track-etch dosimeters throughout 1991. The dosimeters were exchanged monthly for all employees. The results obtained from the study for each monthly exchange period extending from December 1990 through December 1991 have been analyzed. Dose calculation from the Hanford albedo dosimeter was based on the simplified algorithm used since 1989 or on the historical algorithm. The historical algorithm was used exclusively from 1972 to 1989 and selectively since 1989, depending on the dosimeter response; whenever the historical algorithm was used, the record received a Note Code 53 flag.

The results calculated for the CR-39 track-etch dosimeter were significantly lower than the albedo dosimeter results, using either the simplified or historical algorithm. However, it is important that information in Brackenbush et al. (1991) be used in the interpretation of this information. It is known that the thermoluminescent dosimeier (TLD) overestimates the dose for a significantly thermalized field and the CR-39 probably underestimates the dose. It is apparent that the neutron field is often significantly thermalized for the seven employees included in this study.

The relationship between the TLD and CR-39 dosimeter results becomes erratic below a TLD-measured dose of about 30 mrem. There is an inherent problem with the CR-39 dosimeter results for these low doses because of the relatively large background count for the individual folls. When the combination TLD/CR-39 dosimeter is used in the future, current plans are to evaluate the CR-39 dosimeters only when the TLD result is greater than a stated level, assumed to be $50 \mathrm{mrem}$ at this time, to ensure that the CR-39 dosimeter would provide

beneficial information. Some consideration must also be given to the effects of thermalization 
of the neutron spectrum, as measured with the TLD. The commercial neutron albedo dosimeter (due for distribution in CY 1994) will provide more spectral information than the current albedo dosimeter.

\subsubsection{Glow Curve Analysis}

All dosimeter results are examined by computer codes, which examine characteristics of the glow curves obtained for each dosimeter position. The codes are capable of detecting abnormal curves involving fluorescence of dirt or chemical contamination (e.g., oil, etc.), noise during initial chip processing, unaccept-able residual at the end of chip processing, and delay of the glow curve peak. This capability has been extremely useful in evaluating dosimeter processing equipment and the dosimeters. For example, a delay in the glow curve peak may indicate that the dosimeter should be removed from service because of fatigue in the Teflon enclosure. The glow curves are maintained for a period of 18 months for use in responding to any questions of processing integrity.

\subsubsection{Performance Testing of Reader Systems to 500 Rad}

During $199 i$, the performance of the automated reader systems was characterized to 500 rad to ensure compliance with DOE Order 5480.15. An improved procedure was developed to calculate radiation dose when exposures exceed $10 \mathrm{R}$. The method involves using the glow curve data collected for each dosimeter processed. The reader count in each channel of the glow curve is corrected for counting dead time. A revised integrated count for the entire glow curve for each dosimeter position is determined by summing the corrected count for each channel. Thereafter, dose assessment is conducted using routine procedures.

Without correction, the reader systems report doses 3-6\% low at a given dose of 50 rem and 25-35\% low for a given dose of 500 rem. The dead time correction factor of $6.15 \times 10^{-7}$ used previously appears to be within $\pm 10 \%$ of any value determined from current data. The uncorrected and corrected dose values are shown in Figure 4.1. Improved performance resulted from calculations using each channel of the glow curve for the chip in position number 2 of the dosimeter, instead of using the integral values provided by the reader system. However, differences between the previous and improved methods are greater than $10 \%$. This method was used to recalculate the 1991 DOELAP performance testing data. The original and recalculated results are shown in Figure 4.1. The standard error between dose calculated with the new dead-time correction factor and the given dose is about 5\%. 


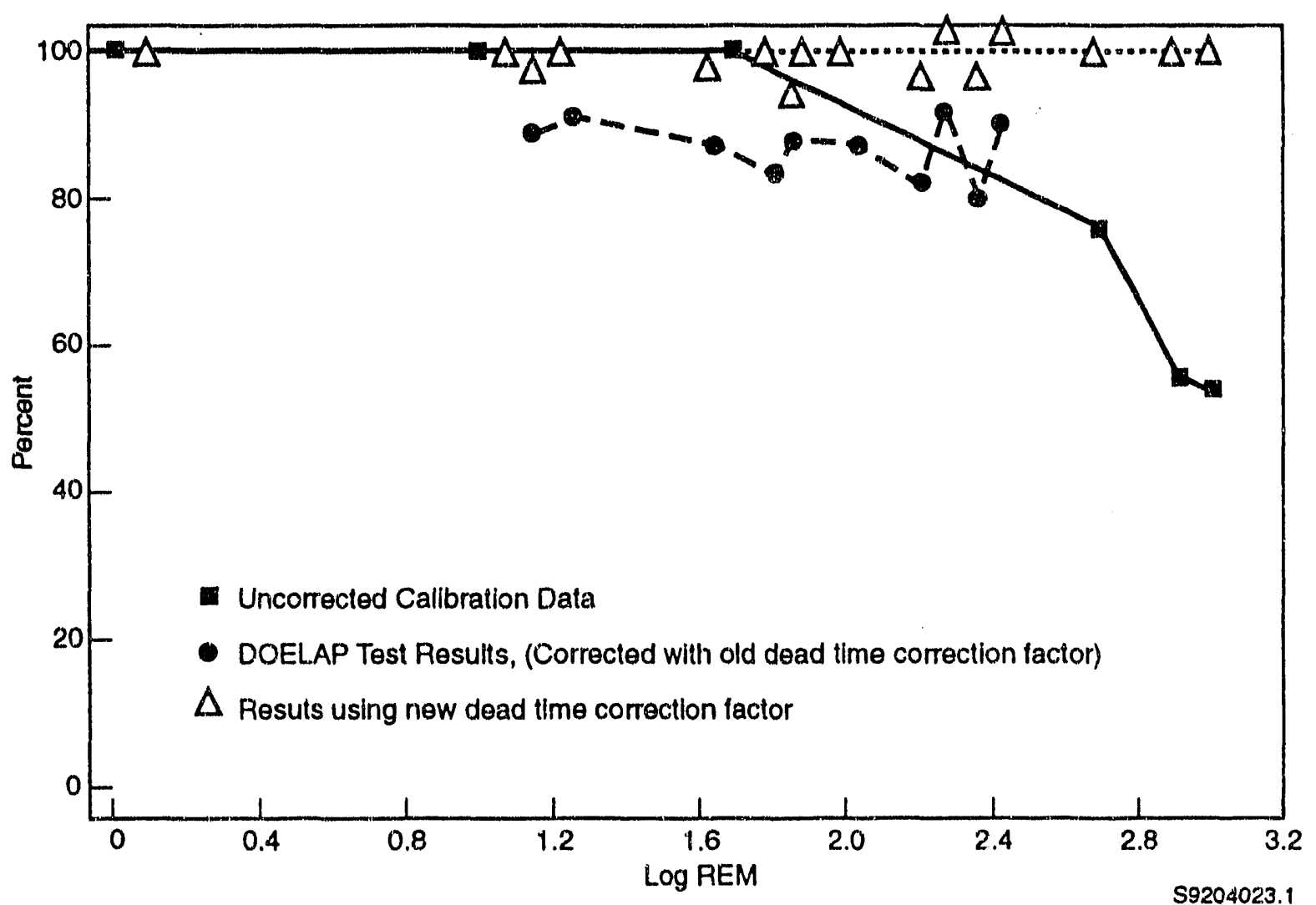

FIGUAE 4.1. Corrected and Uncorrected Dose Response for Hanford Automated Reader System

\subsubsection{Ultraviolet Response of Hanford Dosimeters}

An interesting evaluation was performed during 1991 involving seemingly inexplicable sporadic shallow dose results between 10 and 200 mrem for a specific group of welders. Although the doses were relatively low, no reported dose was expected. An examination of the dosimeter data showed an abnormal pattern of chip data, possibly indicating beta radiation exposure of only low penotrating energy. Only the lightly shielded chip in position number 1 of the multipurpose dosimeter showed any response. The glow curves were compatible with the pattern expected from radiation exposure.

During the investigation, it was learned that occasionally the dosimeters were worn improperly without a security credential. It was suspected that the measured chip signal was the result of ultraviolet (UV) exposure of the chip in the open window (e.g., position number 1). An experiment was conducted in which dosimeters in several different configurations were exposed during typical welding operations. The average distance between the are and the dosimeter was about $41 \mathrm{~cm}$ (16 in.). The results of these 
experiments showed conclusively, based on the pattern of dosimeter response and the glow curves, that the response was a direct result of UV exposure from the welding. Any material, including the transparent multipurpose dosimeter holder, was capable of completely blocking the UV exposure.

\subsection{DOCUMENTATION}

Formal documentation of the Hanford External Dosimetry Program is contained in two PNL manuals:

- Location of Criticality Alarms and Nuclear Accident Dosimeters at Hanford, PNL-MA-583.

- Hariford External Dosimetry Program, PNL-MA-568.

In addition to these documents, the External Dosimetry Program staff maintains eight internal technical documents describing the design, algorithm, calibration, and dose response characteristics of the different dosimeters as well as procedures for evaluating the nuclear accident and environmental dosimeters:

$\begin{array}{ll}\text { Volume I } & \text { Baumgartner, W. V., Quality Assurance, 1991 } \\ \text { Volume II } & \text { Endres, A. W., Personnel Dosimeter Features, Calibration and Dose } \\ & \text { Assessment, 1991 } \\ \text { Volume III } & \text { Schur, J. A., Data Processing, 1991 } \\ \text { Volume IV } & \text { Reese, S. R., Nuclear Accident Dosimetry, 1992 } \\ \text { Volume V } & \text { Baumgartrier, W. V., Dosimeter Reader Systems, } 1991 \\ \text { Volume VI } & \text { Endres, A. W., Field Measurements, 1991 } \\ \text { Volume VII } & \text { Endres, A. W., Environmental Dosimetry, 1992 } \\ \text { Volume VIII } & \text { Peters, J. D., Laboratory Procedures, 1992. }\end{array}$

These documents are used to administer the External Dosimetry Program. In addition, letter reports are prepared and submitted to the Hanford Personnel Dosimetry Advisory Committee for review and comment for significant program issues. Copies are included in the minutes of these committee meetings and provided to the Hanford Radiation Protection Historical Files.

\subsection{PUBLICATIONS}

Brackenbush, L. W., W. V. Baumgartner, and J. J. Fix. 1991. Response of TLD-Albedo and Nuclear Track Dosimeters Exposed to Plutonium Sources. PNL-7881, Pacific Northwest Laboratory, Richland, Washington. 
Fix, J. J., and E. S. Gilbert. 1991. "Consistency of External Dosimetry in Epidemiologic Studies of Nuclear Workers." ORNL/TM-11881, Proceedings of the Third Conference on Radiation Protection and Dosimetry, October 1991.

Fix, J. J. 1991. "Hanford Personnel Neutron Dosimetry Problems and Solutions." In Proceedings of the 11 th DOE Workshop on Neutron Dosimetry, June 4-6, 1991, Las Vegas, Nevada.

\subsection{PROGRAM-RELATED PROFESSIONAL ACTIVITIES}

Fix, J. J.-Chairman of DOE Comprehensive Epiderniologic Data Resource dosimetry working group.

Fix, J. J.-Chairman of DOELAP Oversight Board, as identified in DOE Order 5480.15, "Department of Energy Laboratory Accreditation Program for Personnel Dosimetry."

Fix, J. J.-Member of DOE ad hoc working group to develop extremity dosimeter performance standard.

Fix, J. J.--Member of Health Physics Society Standards Committee Working Groups: to revise ANSI N319, "Personnel Neutron Dosimeters (Neutron Energies Less Than $20 \mathrm{MeV}$ ); to prepare PlanCo 55, "How to Estimate the Overall Accuracy in Occupational Dose Determinations"; to revise ANSI N545, "American National Standard Performance, Testing, and Procedural Specifications for Theirnoluminescent Dosimetry (Environmental Applications)"; and to prepare ANSI N13.29, "Criteria for Testing Environmental Dosimeter Performance."

Fix, J. J.-Member of ad hoc dosimetry working group to support International Agency for Research on Cancer project to pool existing epidemiological studies. 


\subsection{INSTRUMENT CALIBRATION AND EVALUATION PROGRAM}

The operation of a complete radiation protection instrument program is an integral part of the Hanford Site radiation protection program. The Instrument Calibration and Evaluation Program provides a complete radiation protection instrument service, thereby providing the Hanford contractors with a reliable and accurate instrumentation pool capable of performing at the level necessary to ensure personnel safety, as required by DOE Order 5480.11 (1990) and RLIP 5480.11 (1991). Calibrations are performed using the guidance in ANSI N323-1978 (ANSI 1978). The routine program activities fell under the four base tasks that composed the CY 1991 program: 1) the routine portable instrument pool, 2) the Hanford Instrument Evaluation Program, 3) the calibration of WHC 200-Area continuous air monitors (CAMs), and 4) the testing and evaluation of new-generation CAMs.

\subsection{ROUTINE PROGRAM}

The routine program provides a complete radiation protection instrument program. A pool of portable and semi-portable radiation protection instrumentation is maintained for contractor use. Maintenance of the instrument pool involves procuring new and replacement instruments; overseeing an instrument pickup and delivery service; maintaining calibration records; and surveying, decontaminating, maintaining, and calibrating instruments. The routine program also includes the following:

- maintaining the traceability of radiological and electronic calibration systems to the NIST

- operating a program to service radiation protection emergency kits

- modifying and updating written calibration procedures as new instruments are introduced and calibration techniques are improved

- procuring, acceptance-testing, calibrating, and distributing pencil dosimeters

- performing specification development and acceptance testing on all instruments purchased for pool use and as required by Hanford contractors

- fabricating and certifying instrument performance check sources for Hanford contractors. 


\subsubsection{Routine Portable Instrument Pool}

Table 5.1 illustrates the usage of portable instruments on the Hanford Site during CY 1991. Listed are instrument types, the number of instruments, and the percent of the total number of instruments for each contractor (i.e., PNL, KEH, and the WHC 100, 200, and $300 / 400$ Areas). The instrument types are described in detail in PNL-MA-562. (a)

During 1991, a number of new instruments were procured to replace instruments damaged or buried as a result of contamination. A total of 30 Eberline Model RO-3B cutie ples (CPs) were procured. One-hundred Bicron count-rate meters were also received. Onehundred pancake probes wore fabricated by PNL Craft Service personnel and are now in the instrument pool.

As part of a complete portable instrument program, design and procurement were initlated for multirange, check-source devices to verify the calibration of instruments in the field. Check-source devices for the Geiger-Mueller (GM) pancake survey meters, the portable alpha monitors (PAMs), and the microREM, low-range gamma survey meters were specified for procurement. To complement these devices and the existing Hanford Site instrument check sources, a program to ar lually verify and recertify the check sources was established. The program's source calibratio capabilities have been significantly upgraded to allow for the recertification of sources. Triee counting systems will provide this source certification service: a windowless propo' tonal detector; a proportional portal monitor detector; and a newly procured large-area flow-through proportional counting system.

\subsubsection{Hanford Instrument Evaluation Program}

The Hanford Instrument Evaluation Committee (HIEC) provides a Hanford intercontractor information exchange that allows the highost quality portable and semi-portable radiological protection instrumentation program to be maintained at Hanford. Responsibilities of the committee include:

- discussing and proposing solutions to ongoing or potential radiological instrumentation problems and needs onsite

- identitying new radiological instrumentation avallable from manufacturers that may be useful to the Hanford Site operations

- overseeing the procurement of the instruments and reviewing the evaluations of the performance by contractor organizations

(a) Pacific Northwest Laboratory (PNL). Radiation Protection Instrument Manual (Internal Manual). PNL-MA-562, Richland, Washington. 


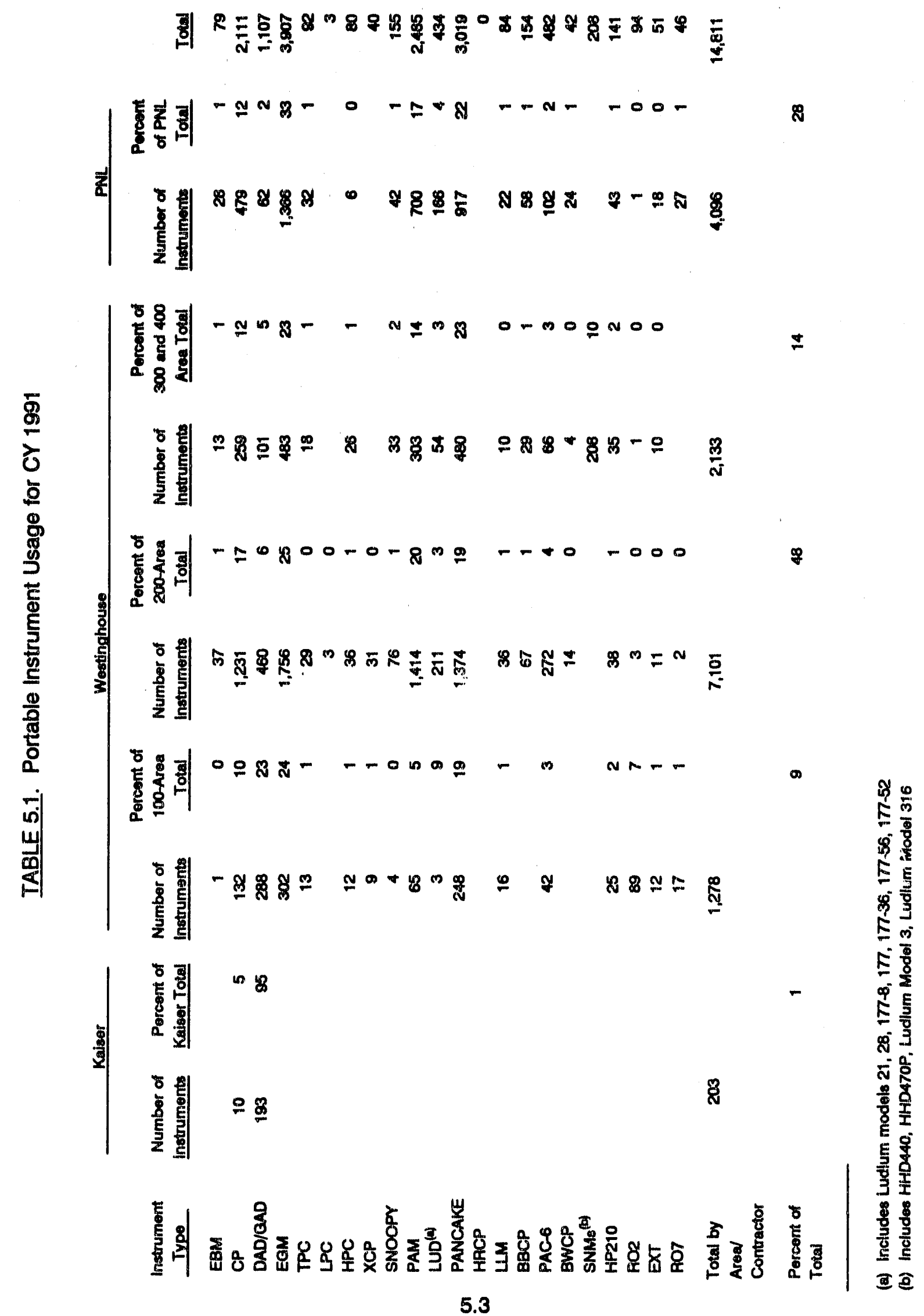


- establishing or reviewing minimum acceptable operational criteria for portable and semiportable radiological instrumentation used for safety on the Hanford Site

- promoting information exchange between contractors on radiological protection instrumentation usage and problems/resolutions.

Representatives from all of the Hanford contractors and a representative of DOE are on this committeo.

\subsubsection{Calibration of WHC 200-Area Alpha Continuous Air Monitors}

In August 1990, PNL began to calibrate $100 \%$ of the WHC 200-Area alpha CAMs. This completed a transition initiated in a letter distributed in September 1989 from A. J. Rizzo, Assistant Manager for Operations (RL), to J. E. Nolan, President of WHC. The letter stated that a transfer of all alpha-CAM calibration responsibility from the 200 Areas to PNL was to take place by December 31, 1989. During CY 1991, the assumption of all the alpha CAMs was completed. Pacific Northwest Laboratory worked closely with WHC to integrate WHC alpha CAMs into the existing PNL alpha-CAM calibration program. Detailed service histories were started on the CAMs to trend and detect substandard performance.

\subsubsection{Testing and Evaluation of a New-Generation Alpha Continuous Air Monitors}

Continuous air monitors are an integral part of Hanford safety programs designed to protect workers from airburne radioactive materials. However, because of the strong and highly variable nature of natural radon backgrounds at many Hanford facilities, it has been impractical to operate existing plant alpha CAMs at the 8 DAC-hour sensitivity required by DOE Order 5480.11, due to excessive false alarm rates. As a result, a joint PNLWHC effort has been initiated to ovaluate and field test a new generation of alpha CAM that has greater background discriminating capabilities than instruments currently in use.

\subsection{SUPPORTING INVESTIGATION AND STUDIES}

The Instrument Calibration and Evaluation Group has also performed a series of laboratory and field tests to determine the ability of Hanford's portable sunvey instruments to detect radioactive surface contamination. This semi-empirical study has combined instrumental, statistical, and human factors as necessary to derive operational detection limits. The data obtained from these studies have been condensed and extended to allow derived threshold detection values to be directly compared to existing contamination control requirements established by DOE Order 5840.11 . The results of this evaluation were 
presented to the Hanford instrumentation Forum, and technical review comments were solicited from its members. A final technical report was prepared and presented at the DOE Radiation Protection Conference, held in Knoxville, Tennesse日, on August 27-29, 1991.

\subsection{PRESENTATIONS}

Goles, R. W. 1991. "Minimum Detectable Activities of Portable Contamination Control Survey Instruments." Presented at the DOE Radiation Protection Confer ince, August 26-29, 1991, Knoxville, Tennessee.

\subsection{PROGRAM-RELATED PROFESSIONAL ACTIVITIES}

D. M. Fleming-Member of Task Group 4, writing a National Council on Radiation Protection and Measurements (NCRP) Handbook, entitled, "Calibration of Survey Instruments for the Assessment of lonizing Radiation Fieids and Radioactive Surface Contamination." 


\subsection{RADIATION STANDARDS AND CALIBRATIONS PROJECT}

The Radiation Standards and Calibrations (RS\&C) Project maintains radiological standards, special instrument and dosimeter response-characterizing equipment, and calibration data-handling equipment at Hanford. This activity provides the means to characterize response to various radiation fields encountered at Hanford and ensures that calibration fields are described in accordance with recommended standards and guides. It also includes $Q A$ responsibilities for routine calibration of instruments and dosimeters. The project routinely

- reviews calibration standards, regulations, and handbooks

- ensures that the calibrations procedures used are in agreement with technically accepted methods

- maintains basic radioactive sources and instruments that serve as radiological standards

- provides traceability of the calibration sources to the NIST

- maintains a data management system for instrument repair and calibration records.

Project activities conducted during CY 1991 are discussed in the following sections.

\subsection{ROUTINE PROGRAM}

The project's routine program comprises two major functions: 1) maintenance of radiological standards and capabilities and 2) maintenance of a computerized data management system.

\subsubsection{Standards and Capabilities}

The radiological standards arict capabilities maintained for the various entities of Hanford Radiological Protection Support Services include gamma, beta, and neutron isotopic sources and $x$-ray generating devices. These standards and capabilities are configured to deliver well known and easily reproduced quantities of radiation dose or exposure to environmental or personnel dosimeters and instruments for providing NIST-traceable calibration and/or response characterization. Photon and beta sources are periodically intercompared with the NIST through either transfer standard instruments submitted by the NIST or from direct measurements by NIST personnel within the PNL facility. Neutron sources undergo direct calibration at the NIST facility before being placed into service at PNL. 


\section{Gamma Ray Photon Sources}

Avallable photon sources include various activities of ${ }^{137} \mathrm{Cs}$ and ${ }^{60} \mathrm{Co}$ configured in either collimated-beam, well, or open field geometries, and a single ${ }^{241}$ Am source configured for irradiation in a $2 \pi$ geometry, as listed in Table 6.1.

The "open" sources listed in Table 6.1 are placed in the center of a circular, aluminum table via a pneumatic air systern. Two discrete distances to the source are typically characterized. "Beam" sources, except for No. 318-131, provide a continuum of exposure rates by using a target positioning stand located on a sliding rail system. Source No. 318131 also includes a moveable target stand, but is typically characterized and used only at two positions: 1 and 3 meters. Target (instrument and/or dosimater) placement for the most commonly used positions within these beam Irradiation facilites is enhanced by laser

TABLE 6.1. Available Photon isotoplc Sources

\begin{tabular}{|c|c|c|c|c|}
\hline Geometry & $\begin{array}{c}\text { Nominal Rate/Range, } \\
\mathrm{R}(\mathrm{rem}) / \mathrm{hr}\end{array}$ & $\begin{array}{l}\text { Location in } \\
\text { Bldg. } 318 \\
\end{array}$ & $\begin{array}{l}\text { Fleference } \\
\text { No. }\end{array}$ & $\begin{array}{l}\text { Primary Photon } \\
\text { Energy, MoV }\end{array}$ \\
\hline & & $80 \mathrm{mon}$ & $\ldots$ & \\
\hline Well & $0.006-2.000$ & Rm. 121 & $318-027$ & $1.17 / 1.33$ \\
\hline Open & $2 / 7$ & Rm. 106 & $318-164$ & $1.17 / 1.33$ \\
\hline Boam & $10-300$ & Am. 8 & $318-037$ & $1.17 / 1.33$ \\
\hline \multirow[t]{2}{*}{ Beam } & $90-3000$ & Prn. 8 & $318-036$ & $1.17 / 1.33$ \\
\hline & & ${ }^{137}$ Cs $\ldots$ & $\ldots$ & \\
\hline Woll & $0.002 \cdot 0.100$ & Rm. 121 & $318-031$ & 0.662 \\
\hline Well & $0.040-10.000$ & Rm. 121 & $318-030$ & 0.662 \\
\hline Beam & $0.100-30.000$ & $\mathrm{Rm} .8$ & $318-040$ & 0.662 \\
\hline Open & $0.400 / 2.000$ & Am. 106 & $318-001$ & 0.662 \\
\hline Beam & $1 \cdot 300$ & $\operatorname{Rim} .8$ & 318.044 & 0.662 \\
\hline Open & $1 / 8$ & Rm. 106 & $318-029$ & 0.662 \\
\hline \multirow[t]{2}{*}{ Beam } & $3 / 30$ & Rm. 6 & $318 \cdot 131$ & 0.662 \\
\hline & & ${ }^{241} \mathrm{Am}$.. & $\ldots \ldots$ & \\
\hline Open $(2 \pi)$ & 0.125 & Am. $s$ & $318-184$ & 0.060 \\
\hline
\end{tabular}


alignment. Well" sources also provicie a continuum of exposure rates and facilitate instrument adjustments during irradiation without undue exposure to personnel. Source-totarget distance is controlled by moving the sources on a trolley system up and down within the well (\$ee Figure 6.1), via computer interface.

\section{X-ray Photon Sources}

Two identical Phillips Model-324 x-ray machines are currently in use to support the RS\&C Program. One machine produces bremsstrahlung (broad) photon spectra (e.g., NIST techniques $\mathrm{M} 30, \mathrm{M} 50, \mathrm{H150}$, etc.), and the other is configured to facilitate production of $\mathrm{K}$ fluorescence technique (narrow) secondary photon spectra (soe Figure 6.2) within a shielded enclosure, known as a "HOG" (see Figure 6.3). Table 6.2 provides a complete listing of available techniques and their characteristics. Both of these systems use a laser alignment system to aid in target (instrument/dosimeter) positioning.

All gamma photon sources undergo annual calibrations and quarterly constancy checks. Selected ${ }^{60} \mathrm{Co}$ and ${ }^{137} \mathrm{Cs}$ sources and $\mathrm{x}$-ray techniques undergo periodic intercomparisons to similar photon sources/techniques at the NIST through the use of a suitable transfer instrument. Each radiation field is assessed at the most commonly used positions.

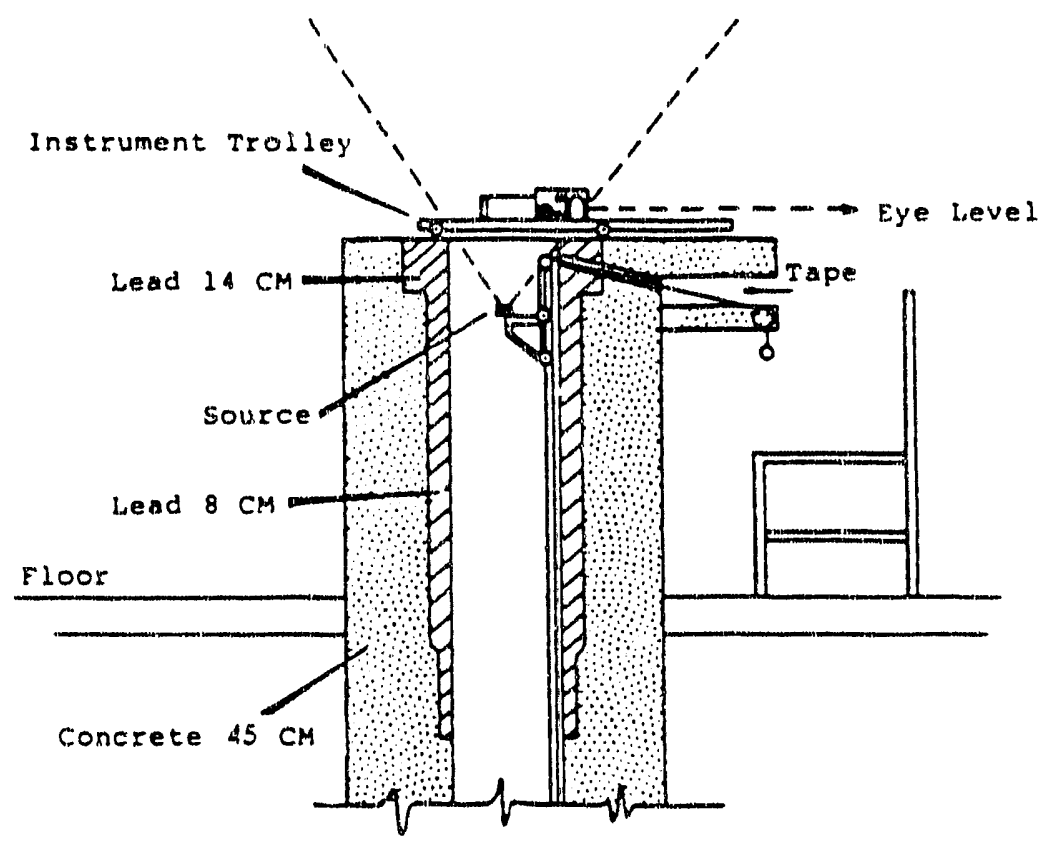

FIGURE 6.1. Typical Calibration Well 


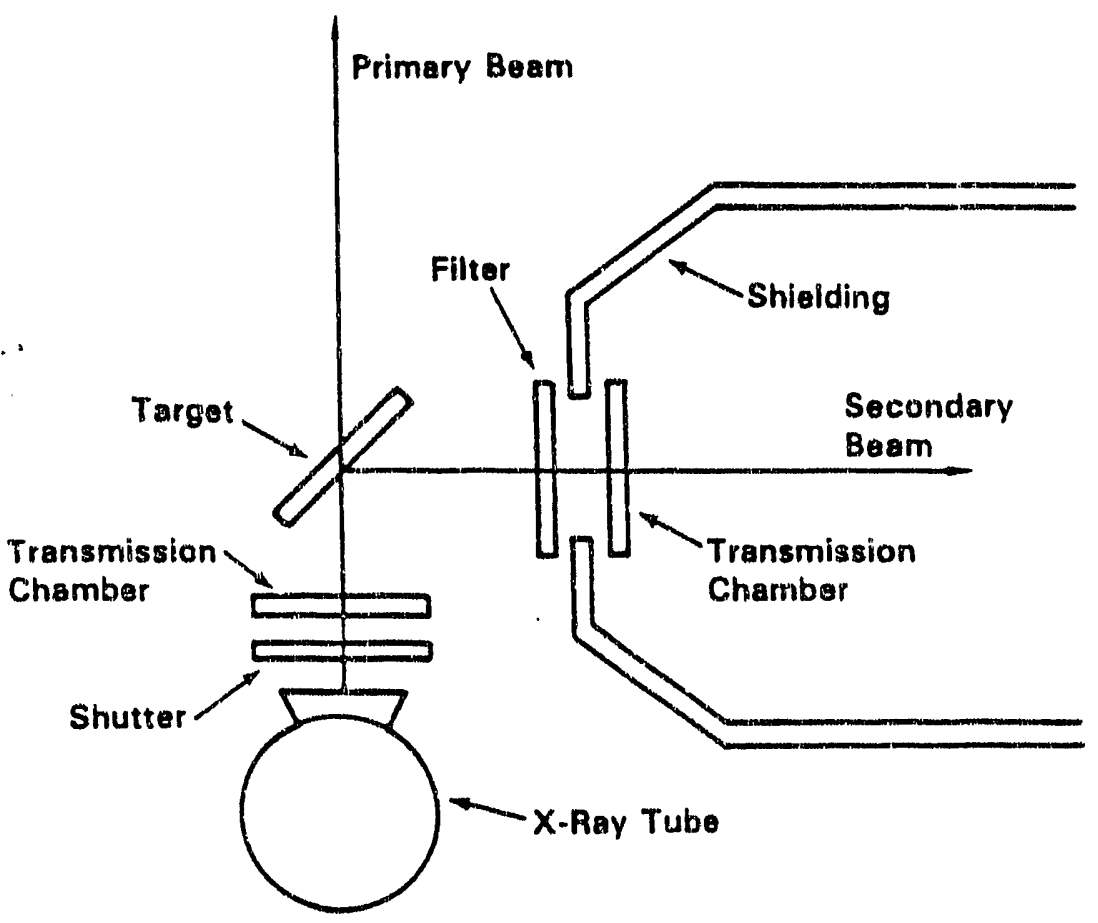

FIGURE 6.2. Schematic Diagram of the K-fluorescence X-ray Technique

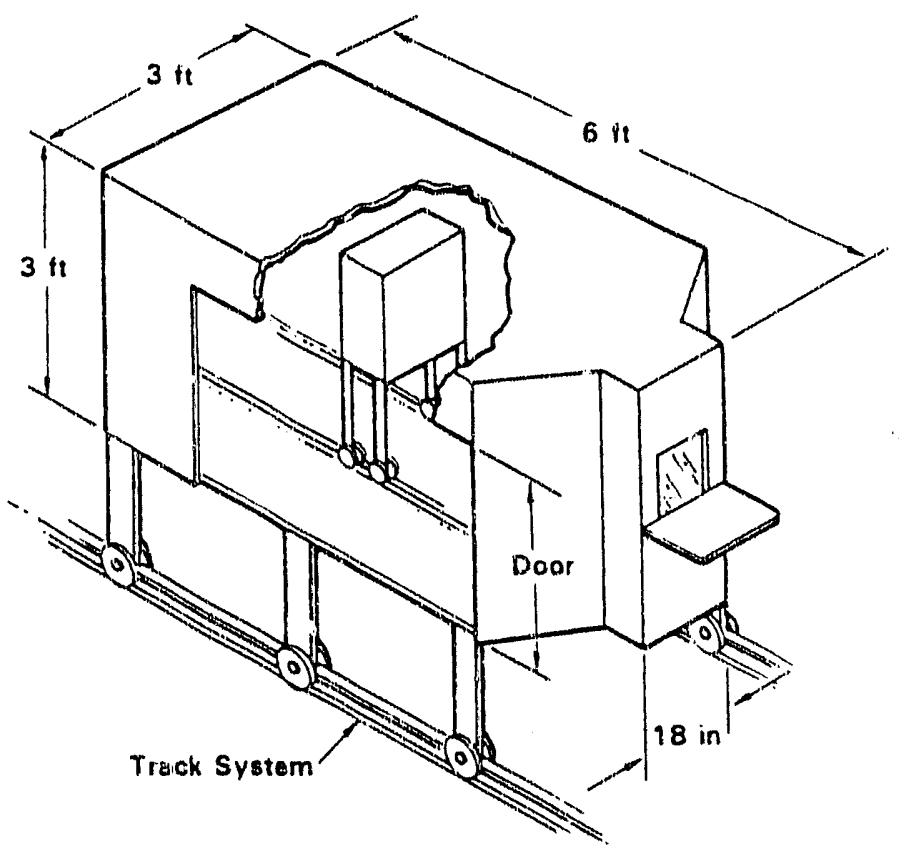

FIGURE 6.3. Schematic of "HOG" Shield Systern Used for K-fluorescence $X$-ray Technique 
IABLE 6.2. Available X-ray Photon Techniques $(a)$

\begin{tabular}{|c|c|c|c|c|}
\hline Technique & $\begin{array}{c}\text { Average/ } \\
\text { Effective Energy, } \\
\begin{array}{c}\mathrm{keV} \\
\end{array}\end{array}$ & $\begin{array}{l}\text { Half-Value } \\
\text { Layer, } \\
\text { mm Al } \\
\end{array}$ & $\begin{array}{c}\text { Homogeneily } \\
\text { Coefficient }\end{array}$ & $\begin{array}{c}\text { Nominal Rate/ } \\
\text { Range, R/hr }\end{array}$ \\
\hline \multicolumn{5}{|c|}{............ Bremsstrahlung - ........... } \\
\hline M2O & 128 & 0.150 & 0.790 & $2.9-288.6$ \\
\hline 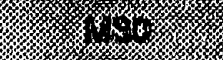 & $s^{2}$ & 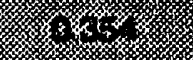 & 46ris & 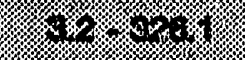 \\
\hline (1) & 3. & $(96 \%$ & 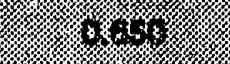 & 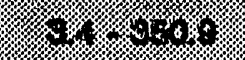 \\
\hline (10.8 & 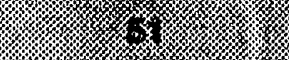 & (3) & 1080. & $4.640 .8 \%$ \\
\hline 48 & (6) & 8 & 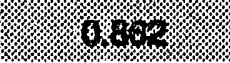 & 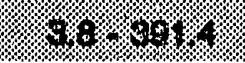 \\
\hline M200 & 84 & N/A & N/A & $4.3-431.0$ \\
\hline (4) & 4 & 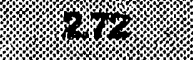 & 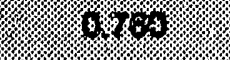 & 40.8 .499 .9 \\
\hline 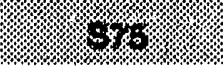 & 6. & 80 & 6ros. & 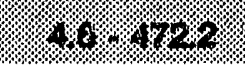 \\
\hline H50 & 38 & N/A & N/A & $0.05 \cdot 9.40$ \\
\hline $\mathrm{H} 100$ & 70 & 13.47 & 0.964 & $0.02-3.07$ \\
\hline 4180. & 28 & $16 \%$ & 98980 & 892.18 .8 \\
\hline $\mathrm{H} 200$ & 167 & 20.22 & 0.994 & $0.09 \cdot 9.22$ \\
\hline $\mathrm{H} 250$ & 210 & 22.48 & 0.987 & $0.09-8.50$ \\
\hline $\mathrm{H} 300$ & 252 & 23.87 & 0.898 & $0.06 \cdot 5.63$ \\
\hline \multicolumn{5}{|c|}{$\ldots \ldots . . . . . .$. K-fluorescence $\ldots \ldots . . .}$. \\
\hline Zinc & 8.6 & N/A & N/A & 20.43 \\
\hline $10 \% \% 40 \% 111$ & $1785 \%$ & 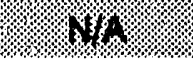 & 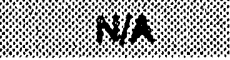 & $80 \%$ \\
\hline $\operatorname{Tin}$ & 25.3 & N/A & N/A & 3.74 \\
\hline Cesium & 31.0 & N/A & N/A & 1.55 \\
\hline Samarium & 40.1 & N/A & N/A & 1.51 \\
\hline Erbium & 49.1 & N/A & N/A & 0.86 \\
\hline 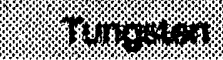 & $6 \% 3$. & 4 & \%il: & $90 \%$ \\
\hline
\end{tabular}

(a) Routine calibration maintained only for the shaded techniques. 


\section{Noutron Sources}

Two configurations of ${ }^{252} \mathrm{Cf}$ neutron sources are available. The first includes two sources of different actlvities placed within the pneumatic system identified for the photon sources listed above. When used, these sources are placed roughly in the geometric center of a room 10-m wide, 14-m long, and 8.8-m high, to create a low-scatter environment. Both sources may be used bare or moderated by a sphere of deuteriated water $\left(D_{2} O\right)$ with a radius of $15 \mathrm{~cm}$ and covered by $0.051 \mathrm{~cm}$ of cadmium. These provide neutron fields useful for instrument calibrations as well as for dosimeter characterization in accordance with specifications of DOE/EH-0027, "Department of Energy Standard for the Performance Testing of Personnol Dosimetry Systems," and ANSI N13.11, "American National Standard for Dosimetry-Personnel Dosimetry Performance-Criteria for Testing." Sources were calibrated at the NIST, and dose rates are verified on a quarterly basis using a laboratory transfer standard survey instrument.

The second configuration includes a third ${ }^{252} \mathrm{Cf}$ source placed in a well to facilitate easy access for instrument calibration. This source provides a fission spectrum partially degraded by the significant scattering from the sides of the well. Because simply accounting for the decay of the source is not sufficient within this geometry, each calendar quarter this source is provided with new calibration dose equivalent rates at key reference points using the laboratory transfer standard survey instrument.

\section{Beta Particle Sources}

Beta particle sources $\left({ }^{204} \mathrm{TI},{ }^{147} \mathrm{Pm}\right.$, and ${ }^{90} \mathrm{Sr} / 90 \mathrm{Y}$, contained in a semi-autornated irradiation jig system, are provided primarily for dosimetry characterization. These "point" sources, with the exception of ${ }^{147} \mathrm{Pm}$, have historically been calibrated directly by NIST personnel or via transfer standard intercomparison with NIST. Currently, no periodic in-house calibration or verification procedures are established. The ${ }^{147} \mathrm{Pm}$ source is generally too weak to assess with currently available instruments. Therefore, the absorbed dose rate provided for this source is as stated by the manufacturer and verified upon initial receipt using a laboratory standard extrapolation chamber.

Several additional sources of each nuclide are available and have been compared to those sources maintained via NIST intercomparison. While these sources contain much the same quantities as the directly traceable sources, some subtleties exist in manufactured geometry and encapsulation. Measurements on some of these sources have been made to verify satisfactory fields, in accordance with ANSI N13.11 (ANSI 1983), DOE/EH-0027 (DOE 1986), and ISO 6980 (ISO 1991). 


\subsubsection{Calibrations and Constancy Checks}

All annual and quarterly calibrations were completed as scheduled in 1991 . The ${ }^{137} \mathrm{Cs}$, ${ }^{60} \mathrm{Co}$, and ${ }^{241} \mathrm{Am}$ photon source callbrations were compared to the originally established dose rates corrected for decay and, with the exception of annual calibrations for sources Nos. 318027 and $318-031$, all were within $\pm 2 \%$ of those established values (see Table 6.3). As a result of annual calibration differences in sources No. 318-027 and 318-031 (wells 4 and 1, respectively), appropriate adjustments were made within the computerized operating systems to reflect the assessed exposure rates. These deviations resulted from various maintenance activities performed on the wells before calibration. Measurements for the ${ }^{252} \mathrm{Cf}$ well source were also performed as scheduled but were not compared to the original NIST-calibrated value since geometry factors severely affect the dose rates.

\subsubsection{Measurement Quality Assurance}

At the end of CY 1991, photon measurement quality assurance (MQA) efforts were in progress. In-house measurements were performed for gamma isotopic sources and selected higher energy $x$-ray techniques (greater than about 35-keV average energy), using a Capintec PM-30 transfer standard. A new transfer standard was purchased, especially for low-energy photon measurements. The new device (see Figure 6.4) is rugged and expected to function well as a transfer standard, which requires regular shipping across the country. Measurements of PNL low-energy photons using this instrument and all of the comparative measurements at the NIST using both transfer standards will continue into early 1992.

After many delays due to personnel and organizational changes at the NIST, an abbreviated beta MQA intercomparison was performed, derived from the transfer standard methodology used in 1986. Measurements from similar NIST and PNL sources, using a NISTowned PTW-2047 transmission chamber, agreed within $\pm 5 \%$. Although this agreement is considered satisfactory by the NIST and by existing in-house procedures, MQA agreement from previous years was much better. Therefore, although the task is considered complete, efforts continue to identity the reason for the increased error.

\subsubsection{Improvements to Standards and Capabilities}

Plans developed in 1990 for modifying the placement and removal system for the $D_{2} \mathrm{O}$ sphere used in the low-scatter neutron irradiation facility were implemented. The previous practice of placing the sphere on the source position was extremely difficult, due to the weight of the sphere, and required direct contact with the potentially toxic cadmium shell. The modifications included construction of a storage assembly, placing an additional track assembly on the access tower for the storage assembly, and adding a jack assembly for raising the sphere into and lowering it out of its irradiation orientation. (See Figure 0.5.) 
TABLE 6.3. Calibration Performance Summary(a)

\begin{tabular}{|c|c|c|c|c|}
\hline \multirow[b]{2}{*}{ Source No. } & \multicolumn{4}{|c|}{ Average of Measured/Known Exposure Rates } \\
\hline & Quarter 1 & Quartor2 & Quarter 3 & Quarter 4 \\
\hline & \multicolumn{3}{|c|}{$\ldots \ldots \ldots . . .{ }^{137} \mathrm{Cs} \ldots \ldots$} & \\
\hline $318-001$ & 1.000 & (2) & 0.998 & 0.990 \\
\hline $318-029$ & 0.997 & $80 \%$ & 1.006 & 0.984 \\
\hline $318-030$ & 0.999 & 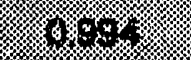 & 1.014 & 1.005 \\
\hline $318-031$ & 0.985 & 0.995 & 0.995 & 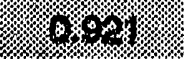 \\
\hline $318-040$ & 1.003 & 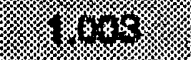 & 1.004 & 1.003 \\
\hline $318-044$ & 1.006 & 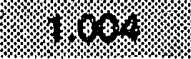 & 1.003 & 1.005 \\
\hline \multirow[t]{2}{*}{$318-131$} & $1.008 \%$ & 0.991 & 1.005 & 1.002 \\
\hline & \multicolumn{4}{|c|}{$\ldots \ldots \ldots{ }^{60} \mathrm{Co} \ldots \ldots \ldots$} \\
\hline $318-027$ & $10 \% \% 6 \%$ & 1.011 & 1.011 & 1.017 \\
\hline $318-036$ & 1.007 & $490 \%$ & 1.005 & 1.006 \\
\hline $318-037$ & 1.008 & $80.07 \%$ & 1.005 & 1.007 \\
\hline \multirow[t]{2}{*}{$318-164$} & 0.994 & 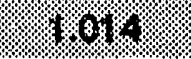 & 1.006 & 0.984 \\
\hline & \multicolumn{4}{|c|}{$\ldots \ldots \ldots{ }^{241}$ Am $\ldots \ldots \ldots$} \\
\hline $318-184$ & $1 \% 40 \%$ & 1.003 & 1.008 & 1.014 \\
\hline
\end{tabular}

(a) Annual calibrations are shaded.

\subsubsection{Maintenance of the Data Management System}

The instrument tracking system includes an HP 9000 computer, its peripherals, and the data management software. All software used in the Hanford Radiological Protection Support Services is written in-house using the HP ALLBASE/HP-UX database system. This software accesses and is used to create the databases CALIB, PENCIL, and OLDCAL, originally combined as the single database CALDB, to track the routine maintenance, repair, and calibration of radiation monitoring equipment as well as to identify and locate information. As part of the effort to integrate a new disk drive and increase system performance, the CALDB 


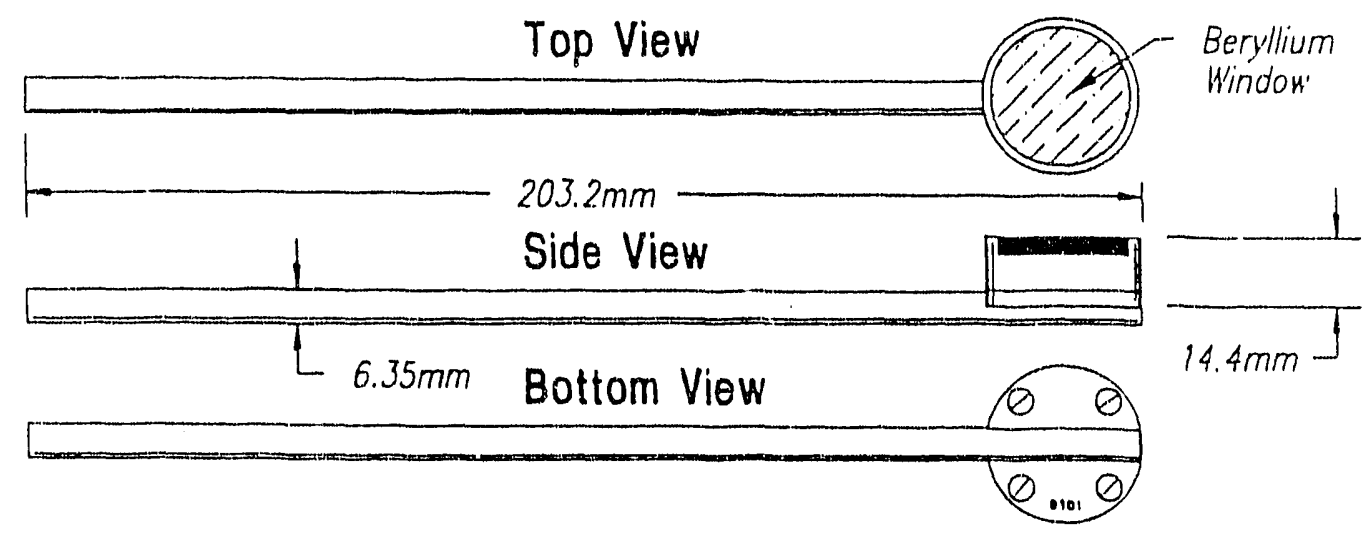

FIGURE 6.4. Schematic of Precision Radiation Measurement Model LE-0.8 Low-Energy lonization Chamber

database was split between two databases with the primary database, CALIB, maintaining only the most recent 10 calibrations for each instrument. Prior calibration records, accessed only occasionally, were placed into an auxiliary database, OLDCAL. By transferring much of the historical calibration data to the auxiliary database, the rates of data storage and of retrieval and search processes were improved. PENCIL is used to track personnel pencil (self-reading) dosimeters and can be used to create lists of "calibration-due" in truments.

\subsubsection{Improvements to the Data Management System}

Two hardware upgrades were introduced to improve the system capability. A second 670-Mb hard disk drive unit has been added to the system to expand the data storage capacity. During much of the year before its installment, the single existing disk was used at approximately $95 \%$ capacity, which left little room for additional data storage and caused data search routines to proceed slowly. All databases were placed on the new disk drive unit with the existing drive reserved for program storage.

The second hardware improvement involved the integration of a 650-Mb magnetooptical (MO) disk drive. This unit was added to help facilitate the routine backup of the database and auxiliary programs. Before adding this system, backup was made to magnetic tape cartridge and required several hours to perform. With the new MO system, backups take approximately 1 hour and the entire contents currently existing on both hard disks will fit on a single MO disk. Based on accelerated life tests for the MO disks, the expected (conservative) lifetime for data retention is 10 years; however, current practices call for weekly system backups. 

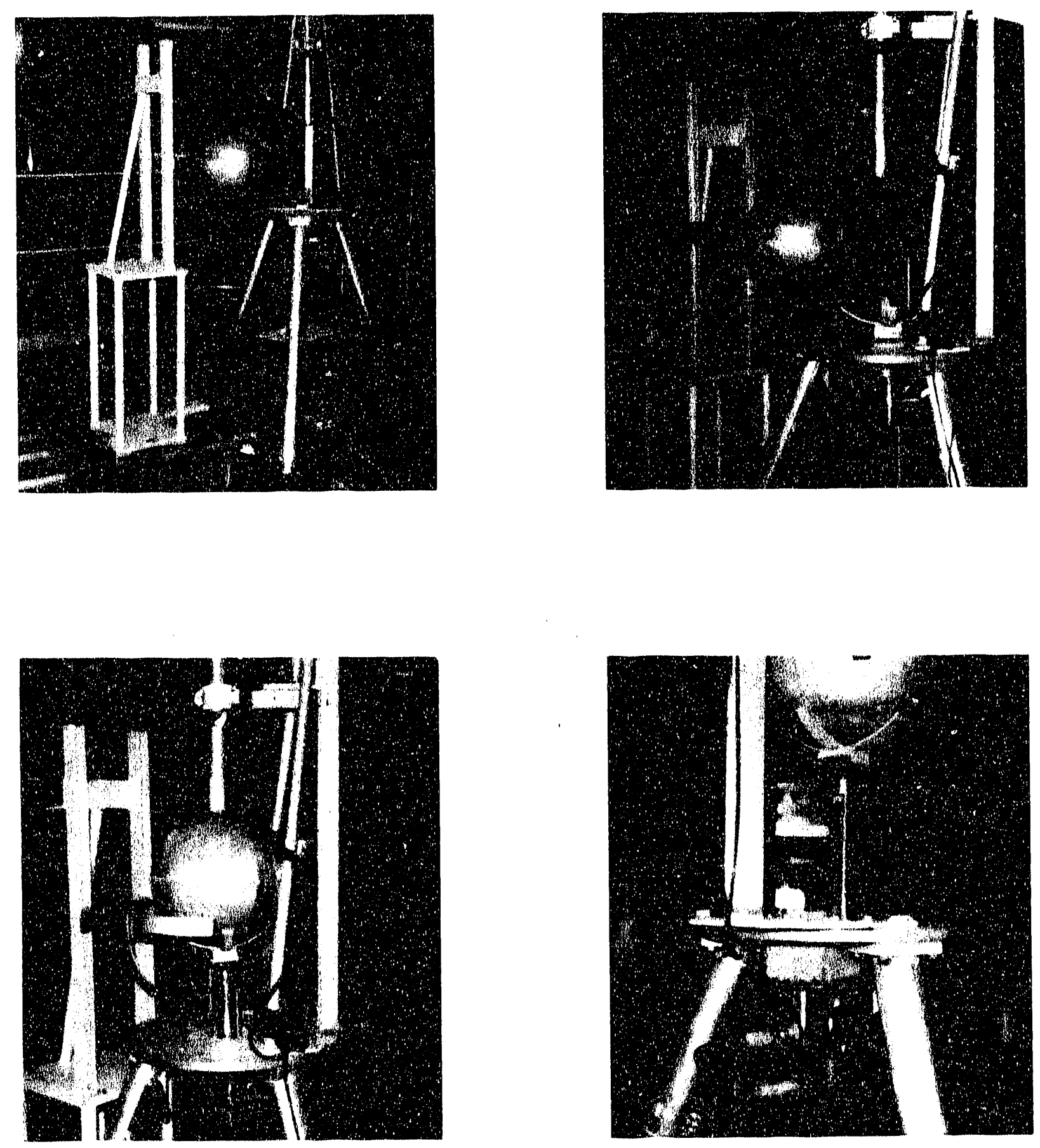

FIGURE 6.5. Placement, Removal, and Storage Assembly for the ${ }^{252} \mathrm{Cf}$ Source $\mathrm{D}_{2} \mathrm{O}$ Moderating Sphere 
Training was initiated for an assistant system administrator, beginning in late 1991, to adequately cover the system operation in case of prolonged or untimely absence of the primary system administrator.

A change in organizational support was also made regarding the database management task. Beginning in September, this task became supported directly by Plantwide Services. This change was made because of insufficient justification for maintaining the same independence from instrument/dosimeter calibration tasks as needed for source calibration tasks. Conversely, direct support to/from Plant-wide Services is expected to improve the line of communication necessary to adequately focus the refinement of the database operations.

\subsection{SUPPORTING INVESTIGATIONS AND STUDIES}

The 1.47-mg ${ }^{252} \mathrm{Cf}$ source (source no. 318-167) placed into the pneumatic system in the low-scatter neutron exposure facility was the suspected cause of elevated neutron background levels recorded on some persennel dosimeters used for unrelated (i.e., nonneutron) testing in nearby areas. This source, installed in 1989, replaced a source more than 5 years old that had decayed significantly. In 1990, initial measurements of adjacent rooms and hallways using a SNOOPY neutron survey meter indicated no measurable evidence of elevated neutron backgrounds. However, TLDs placed in the adjacent control room and within the $x$-ray facility on the level below this area did indicate an increased neutron background, as did tissue equivalent proportional counter (TEPC) measurements.

Extensive follow-up measurements were performed within the control room and the $x$-ray facility, located below the neutron irradiation area, using a directional neutron detector. These measurements indicated that an above-background neutron field was penetrating the ceiling of the control room and coming through floor vents in the low-scatter facility, which lead indirectly into the $x$-ray facility. Corrective action plans were developed to reduce the elevated neutron levels in these external areas through the placement of additional shielding at critical points. Installation of the necessary shielding is expected during 1992. 


\subsection{HANFORD RADIOLOGICAL RECORDS PROGRAM}

The HRRP supports RL and Hanford contractor radlation protection programs by preserving and administering radiological exposure records for all Hanford workers and visitors, past and present. The program is also responsible for the Hanford Radiation Protection Historical Files. Program personnel operate the computer systems and library equipment necessary to input, store, and retrieve the records and produce the required reports.

The records program uses the ORE system, which includes a database with the personnel exposure data that are readily retrievable via a system of personal computers (PCs) and terminals. The ORE system also includes all of the supporting exposure documentation on microfilm that is indexed into a computer-assisted retrieval (CAR) system. The CAR system allows for rapid retrieval of the documents for any individual using identifiers, such as payroll numbers, social security numbers, and names. A database administration function performs system evaluations, troubleshooting, resolution of system and user problems, training of users, oversight of system security, and initiation and testing of modifications to the database.

The historical records include documents such as policies, procedures, reports, and important communications that define the Hanford radiological dosimetry and radiation protection programs during its history. The historical records are microfilmed and indexed into a second CAR system. These records are retrievable by author, date or range of dates, document number (if applicable), title, and up to three keywords.

The program is operated under the applicable sections of ANSI N13.6-1972 (ANSI 1972), and under DOE Orders 1300.1, 1324.2A, 5480.11, and 5484.1 Chg. 3 (1980, 1988b, $1988 \mathrm{a}, 1987 \mathrm{~b}$ ) as assigned by the Hanford Site Services Handbook (RL 1983). It also complies with the applicable sections of the Privacy Act (1974) and the Freedom of Information Act (1966).

\subsection{ROUTINE PROGRAM}

The HRRP is organized into three major functional areas: data handling, report issuance, and the library. Both data handling and report issuance are performed by the Radiological Records Data Processing Center.

Data-handling includes entering data into the ORE database and validating all data entry. Validation is accomplished by establishing audits to be matched to entries of results, resolving unmatched results, and interacting directly with contractor personnel. Data-handling 
also includes dealing directly with the contractor personnel and data suppliers to assist them and solve data problems.

Feport issuance includes generating and issuing routine exposure status reports to the contractors, quarterly manrem and annual statistical reports to DOE, annual reports to employees, and special reports requested by former employees, as well as those requested by the contractors and RL. This function requires close contact with $\mathrm{RL}$, the contractors, and other personnel dosimetry functions.

The library maintains individual exposure records that are not reducible to database elements as well as the Hanford Radiation Protection Historical Files. The library staff file and retrieve current hard-copy documents, prepare documents for long-term storage, and track and account for the documents through the microfilming and indexing process. The library contains the individual exposure records of all Hanford personnel since 1945 (almost fivemillion microforms). There are also some exposure records remaining from the Hanford DuPont era. These and the Historical File microforms are retrievable through two CAR systems that are maintained by the library staff.

Although the results from the dosimeter and excreta processing, as well as the in vivo counts, are received by electronic transmission or magnetic tape, a large amount of data that are placed in the records are received in hard copy form. These data are entered manually by the Data Processing Center staff. The hard copies are then sent to the library for entry into the CAR system. Table 7.1 presents CY 1991 statistical information on many of the documents that are entered into the database and microfilmed and indexed into the CAR system.

Because the ORE system is being redeveloped, changes to the database are being limited to those necessary to keep the system functional, those required by additions or changes to DOE Orders, or those that reduce costs. The only significant permanent change that was made during CY 1991 was the programming of a periodic download of certain exposure data to the HEHF for use by the physicians.

The interim Excreta Bioassay Program caused some changes in the records program. Programming changes to ORE were required because of

- changing examination requirements

- splitting certain samples between different interim laboratories

- adding new laboratory codes

- allowing downloads from ORE to IDP to access data needed for interim laboratories

- allowing uploading of results from IDP through PCs to ORE

- accounting for samples lost at the contract termination. 
Considerable effort was required by HRRP staff to schedule manually and to resolve rejects. The ORE was then reprogrammed to handle the electronic feeds to and from tho new laboratory when the contract was let.

A Dosimetry Records Ljbrary Desk Procedure manual was completed and issued internally. This manual will be used by the records library staff to perform their duties.

TABLE 7.1. Records Activity for CY 1991

Document

Number

Personal Radiation Exposure History Form (used to document exposure history prior to Hanford)

Employee and Dosimetry Change Forms (used to document personnel or dosimetry changes)

Employe日 and Dosimetry Change Forms (used to document employee terminations)

Temporary Dosimeter Assignment Forms (used for visitors and subcontractors as well as employees who forgot their dosimeters)

21,143

Investigation of Dosimeter Result Forms and Change Letters (used to estimate exposure for lost, damaged, or otherwise suspect dosimeter results)

Special Process Forms (used to document data for specially processed dosimeters)

Request for Special Excreta Sample Analyses (used to initiate the collection of samples for analysis)

Requests for Exposure Summaries (summaries requested for current and prior Hanford employees)

Letters Sent to Request Prior Exposure (to request summaries for new employees with prior exposure)

Microfilm reels indexed into CAR (personnel and historical documents, each reel containing over 2000 images) 


\subsection{SUPPORTING TASKS}

Allocations were received in FY 1990 for the start of the ORE redevelopment effort. Allocations for continuing the project were received in FY 1991. The effort will take over two years and contain four main phases. As originally conceived, these phases included:

1. Systems requirements analysis - This analysis involves defining the requirements the new system. The analysis involves interaction with all the users and data suppli determine their needs. From this effort, a requirements document is produced that is used as the basis for designing and constructing the now system.

2. Preliminary design - This step in the redevelopment follows and is based on the requirements analysis. It includes the development of the functional specifications for the new system, an alternatives analysis, and the production of an alternatives analysis document. The alternatives analysis will determine the hardware/software application that will best suit the requirements. This phase also includes the final cost/benefit analysis, as well as schedules and pians for the detailed design and construction, verification, installation, and startup phases.

3. Detailed design and construction - This phase includes the detailed design and programming of the new system defined in the previous two phases and is expected to take at least 12 months. The detailed design portic ; will include tasks such as the functional system design; program design; design testing and analysis; development of system test, certification test, and acceptance test plans; development of a conversion plan; and development of a training plan. The construction portion will include tasks such as coding; unit, integration, and systems testing; and development of convere: and acceptance test materials.

4. Certification and implementation - This phase includes conversion of data from the old to the new system and certification that the installation is correct. Correct installation will be verified by modular, integration, and systems testing. Once testing has shown the new system meets the acceptance criteria, parallel runs of the new system will be conducted with the old ORE. When a successful paraliel run has been completed, the new system will be established as the production system. Training of records personnel and users is included.

The system requirements analysis phase was completed during CY 1990. The preliminary design phase was started during CY 1990 and continued into CY 1991.

The alternatives analysis process reviewed a number of possibie hardware and software alternatives. Four were selected for detailed analysis: 
- LSIS/DB2, which uses IBM's relational database management system (RDBMS) on the Hanford Large Scale Information System NAS 5080 mainframe (LSIS) under an MVS/XA operating system

- Sybase and client server architecture, using a NetFrame NF-200 server running the Microsoft/Sybase SQL Server in an OS/2 environment and PCs using DOS for front-end user interface

- ORACLE RDBMS, running on a Sequent Symmotry S27 parallel processing minicomputer in a software/hardware environment dedicated to REX, using the DYNIX (a variant of UNIX) operating system

- ORACLE RDBMS, running on a Compaq SystemPro high-end super microcomputer using a UNIX-based operating system.

The final recommendation of the alternatives analysis, accepted by the Steering Committee, was the LSIS/DB2 option. The recommendation was based on the success that this system has experienced at Hanford. The L.SIS/DB2 environment provides proven production on-line transaction processing and report-generation capiabilities; a carefully controlled data security, access, and integrity mechanism; and the abilizy to effectively interact with other PC, minicomputer, and mainframe-based applications. The cost of implementation on the LSIS/DB2 system is the lowest of the alternatives. However, its operating expense is higher over a 5-year period than the other alternatives. The study recommended that the make or-break infiuences of enhanced system functionality, support, arid service will more than offset the differences in cost. ${ }^{(a)}$

A 2-month planning phase was added to the schedule at the end of the preliminary design phase. During this phase, the acceptance criteria and a pro uet plan were completed. The acceptance criteria will be the basis for the test plans. (b) The Phase I Sottware Project Management Plan was completed and acceptecl. This plan divided the soltware design and coding activities into tasks of fewer than 80 perison-hours. The plan showed that it would take 14 months to complete the detailed design and cons'ruction phase. This, added to a delay in completion of the alternatives analysis and the aritition of the planining phase, increased the original length of the project by six months. implementation was anticipsted to be in November 1992.

(a) Seesing, P. A., E. F. Talbott, and R. Carriera. 1991. Radiation Exposure System (REX) Alternatives Analysis. Boeing Computer Sirvices-Richland, Fichland, Washington.

(b) Talbott; E. F. 1991. REX Svstem Accertance Criteria. Whir.-SD-GN-CR-3001, Rev. 0 , Boeing Computer Services-Plichland, Richland, Washington. 
The URE Redevelopment Steering Committer decided that the netu system will be named "REX" for Radiation Exposure System. This name was formalin registered.

The detailed design and construction phase was started and continued through the end of the CY 1991. Hanford Radiological Records Program personnel, including the Jatabase administrator and contractor dosimetry records personnel, were involved in the design effort. There has been considerable user input to the project.

The project manager from BCSR left and was replaced in August, requiring a new schodule, with anticipated implementation still November 1992. The principal change was adoption of a design/build mode of development which delays the completion of the software design document (SDD) until completion of the phase; the SDD was originally to be completed and approved before construction started. The SDD sections will be approved as each is completed before that module is coded. As there appeared to be requirements listed in several documents, a requirements traceability matrix was drafted to assure all the requirements are listed in a single document. The matrix was developed from the requirements document, the alternatives analysis document, and the minutes of the ORE Redevelopment Steering Committeo meetings.

An agreement was reached with BCSR that the project would fall under PNL. QA procedures and that HRRP would perform the configuration management functions. A QA Plan and Software Configuration Management Plan were negotiated between HRRP and BCSR.

\subsection{LASER OPTICAL DISK SUBSYSTEM}

A feasibility siudy for a laser optical disk (LOD) subsystem to interface with REX was written in 1990 and approved for acquisition in FY 1992. A requirements document was completed in 1991. The REX system is being designed arourid the use of electronic transaction records, which will replace many of the paper records now used. The volume of these records will create the need for large amounts of data storage. Instead of storing these records on the database, which can use considerable capacity and be costly, they will be stored on a LOD subsystem. Electronic records will be transferred regularly from the LSIS computer and recorded on write-once/read-many LODs. In addition, the remaining paper records can be scanned and recorded on the disks. All records will be inclexed into a database for automated retrieval. The LOD system will he operated by the HRRP library staff, and HRRP is providing project management. 


\subsection{PRESENTATIONS}

Martin, J. B., and M. Lyon. 1991. "Deficiencies In Radiation Protection Records Systems." Presented at the Health Physics Society Midyear Topical Meeting, Raleigh, North Carolina, January 21-24, 1991. Also published in Implementation of Current NCRP and ICRP Guidance and Revised 10 CFR Part 20. Proceedings of the Twenty-founth Midvear Topical Meeting of the Health Physics Soclety, North Carolina Chapter of the Health Physics Society, Raleigh, North Carolina.

Lyon, M., and J. B. Martin. 1991. "Automating Radiation Protection Records Systems." Presented at the Thirty-Sixth Annual Meeting of the Health Physics Society, Washington, DC, July 21-26, 1991.

Seesing, P. R. 1991. "Normalizing Records Data for Relational Databases." Presented at the International Meeting of the Association for Records Managers and Administrators, Orlando, Florida, September 23-26, 1991. Also publlshed in Proceedings of the ARMA International 36th Annual Conference, Orlancio, Florida.

Lyon, M., and J. B. Martin. 1991. "Automating Occupational Protection Records Systems." Preservted at the Thirtieth Hanford Symposium on Heath and the Environment, Current Topics in Occupational Health, Richland, Washington, October 29-November 1, 1991. Also to be published in the meeting proceedings, which will be a supplementary issue of Applied Occupational and Environmental Hygiene, published by the American Conference of Governmontal industrial Hygienists in 1992.

\section{$\%$ PROGAAM-RELATED PROFESSICNAL ACTIVITIES}

Lyon, M.--Chairman of the Health Physics Society Standards Committee Working Group to reviow ANSI N13.6, American Standard Practice for Occupational Radiation Exposure Records Systems. 


\subsection{REFERENCES}

American National Standards Institute (ANSI). 1972. Practice for Occupational Radiation Exposure Records Systems. ANSI N13.6, American National Standards Institute, Inc., New York.

American National Standards Institute (ANSI). 1978. Radiation Protection Instrumentation Test and Callibration. ANSI 323, American National Standards institute, Now York.

American National Standards Institute (ANSI). 1983. American National Standard for Dosimetry. Personnel Dosimetry Performance - Criterla for Testing. ANSI N13.11, Now York.

Brackenbush, L. W., W. V. Baumgartner, and J. J. Fix. 1991. Response of TLD-Albedo and Nuclear Track Dosimetrs Exposed to Plutonium Sources. PNL-7881, Pacific Northwest Laboratory, Rlichland, Washington.

Curry, L. A. 1968. "Limits for Qualitative Detection and Quantitative Determination." Analytical Chemistry 40(3):586-593.

Freedom of Information Act. 1966. Public Law 89-487, July 4, 1966.

International Organization for Standardization (ISO). 1991. Reference Beta Radiations for Calibrating Dosemeters and Doserate Meters and for Determining Their Response as a Function of Beta Radiation Energy. 1506980 , International Organization for Standardization, Geneva, Switzerland.

Lyon, M., T. J. Froelich, D. E. Bihl, J. A. Leonowich, J. J. Fix, T. P. Lynch, and R. K. Piper. 1991. Hanford Radiological Protection Support Services Annual Report for 1990. PNL-7752, Pacific Northwest Laboratory, Richland, Washington.

Privacy Act, 44 Fed. Reg. 510772 (1974).

Roberson, P. L., and R. D. Carlson. 1992. "Determining the Lower Limit of Detection for Personnel Dosimeter Systems." Health Physics 62(1):2-9.

Strenge, D. L., R. A. Peloquin, M. J. Sula, and J. R. Johnson. 1990a. Code for Internal Dosimetry /CINDV Part 1: Conceptual Representation. PNL-7493, Pt. 1, Pacific Northwest Laboratory, Richland, Washington. 
Strenge, D. L., R. A. Peloquin, M. J. Sula, and J. R. Johnson. 1990b. Code for Internal Dosimetry (CINDY) Part 2: User's Guide. PNL-7493, Pt.2, Pacific Northwest Laboratory, Fichland, Washington.

Sula, M. J., E. H. Carbaugh, and D. E. Bihl. 1991. Tochnical Basis for Internal Dosimetry at Hanford. PNL-6866, Rev. 1, Pacific Northwest Laboratory, Richland, Washington.

U.S. Department of Energy (DOE). 1986. Standard for the Perfromance Testing of Personnel Dosimetry Systerns. DOE/EH-0027, Washington, D.C.

U.S. Department of Energy (DOE). 1987a. DOE Laboratory Accreditation Program for Personnel Dosimetry. DOE Order 5480.15, U.S. Department of Energy, Washington, D.C.

U.S. Department of Energy (DOE). 1987b. Environmental Protection, Safety, and Health Protection Information Reporting Requirements. DOE Order 5484.1 (change dated June 15, 1987), U.S. Department of Energy, Washington, D.C.

U.S. Departmeni of Energy (DOE). 1988a. Radiation Protection for Occupational Workers. DOE Order 5480.11, U.S. Department of Energy, Washington, D.C.

U.S. Department of Energy (DOE). 1988b. Records Disposition. DOE Order 1324.2A, U.S. Department of Energy, Washington, D.C.

U.S. Department of Energy (DOE). 1980. Miciographics Management. DOE Order 1300.1, U.S. Department of Energy, Washington, D.C.

U.S. Department of Energy Richland Operations Office (RL). 1983. Hanford Site Services Handbook. RLPI 9-50.5, U.S. Department of Energy, Richland Field Office, Richland, Washington.

U.S. Department of Energy-Richland Operations Office (RL). 1991. Hanford Site Services Handbook. RLPI 9-50.5, U.S. Department of Energy, Richland Field Office, Richland, Washington.

Wilson, R. H., J. J. Fix, W. V. Baumgartner, and L. L. Nichols. 1990. Description and Evaluation of the Hanford Personnel Dosimeter Program From 1944 Through 1989. PNL-7447, Pacific Northwest Laboratory, Richland, Washington. 


\section{DISTRIBUTION}

No. of

Copies

\section{OFFSITE}

2 DOE/Office of Scientific and Technical Information

DOE Albuquerque Field Office

J. B. Martin

Battelle Pantex

Pantex Plant

P.O. Box 30020

Amarillo, TX 79120

L. M. Coco

Mound Laboratory

EG\&G

Mound Applied Technologies

P.O. Box 3000

Miamisburg, $\mathrm{OH} 45342$

J. M. Graf

Los Alamos National Laboratory

P.O. Box 1663

Los Alamos, NM 87545

R. M. Rogers

EG\&G Rocky Flats

Rocky Flats Plant

P.O. Box 464

Golden, CO 80402-0464

DOE Chicago Field Office

A. E. Kouhner

Brookhaven National Laboratory Upton, NY 11973
No. of

Copies

R. E. Toohey

Argonne National Laboratory

9700 South Cass Avenue

Argonne, 1!. 60439

DOE Idaho Field Otfice

H. D. Christiansen

Westinghouse Idaho Nuclear

Company, Inc.

P.O. Box 4000

Idaho Falls, ID 83404

DOE Nevada Field Office

B. P. Smith

Reynolds Electrical and

Engineering Co., Inc.

P.O. Box 98521

Las Vegas, NV 89193

DOE Oak Ridge Field Office

J. S. Bogard

Oak Ridge National Laboratory

Martin Marietta Energy

Systems, Inc.

P.O. Box 2008

Jak Ridge, TN 37831

ง. 8. Plunt

$Y-12$ Plant

Marinn Marietta Energy

Systems, Inc,

P.O. Box 2008

Oak Ridge, TN 37831 
No. of

Copies

DOE San Francisco Field Office

C. T. Prevo

Lawrence Livermore National Laboratory

P.O. Box 808

Livermore, CA 94550

DOE Savannah River Field Otfice

D. A. Stevenson

Westinghouse Savannah River

Company

Savannah River Plant

P.O. Box 616

Aiken, SC 29802

\section{ONSITE}

4 DOE Richland Field Office

D. L. Clark

D. T. Evans

R. A. Holten

G. R. Yesberger

2 Hanford Environmental Health Foundation

R. H. Ronish

M. J. Swint

Kaiser Engineers Hanford

D. J. Foust

3 Westinghouse Hanford Company

W. A. Decker, Jr.

R. E. Heineman

T. J. Kelly
No. of

Copies

1 Washington State University (Tri-Cities)

A. L. Kathren

41 Pacific Northwest Laboratory

W. J. Bair

D. E. Bihl (2)

L. G. Faust

D. M. Fleming

J. J. Fix (2)

T. J. Froelich (2)

D. P. Higby

G. R. Hoenes

J. R. Houston (2)

J. R. Johnson

M. Lyon (10)

T. P. Lynch (2)

J. B. Martin

J. C. McDonald

I. C. Nelson

R. K. Piper (2)

J. M. Selby

K. L. Soldat

Publishing Coordination

Technical Files (5)

Radiation Protection

Historical Files

(c/o V. L. Berndt) (2) 

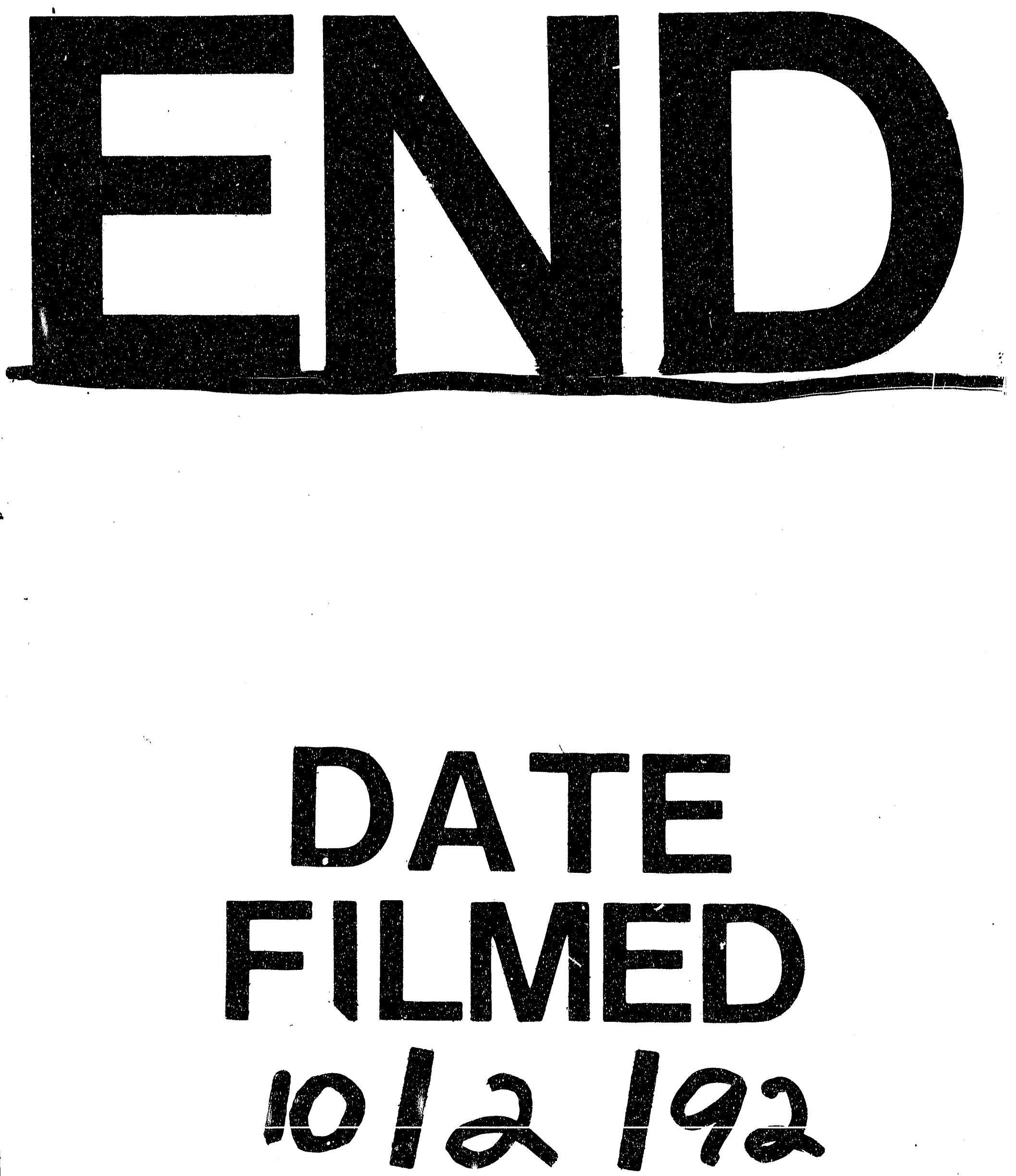
